Prepared in cooperation with the Central Platte Natural Resources District

\title{
Water Movement through the Unsaturated Zone of the High Plains Aquifer in the Central Platte Natural Resources District, Nebraska, 2008-12
}

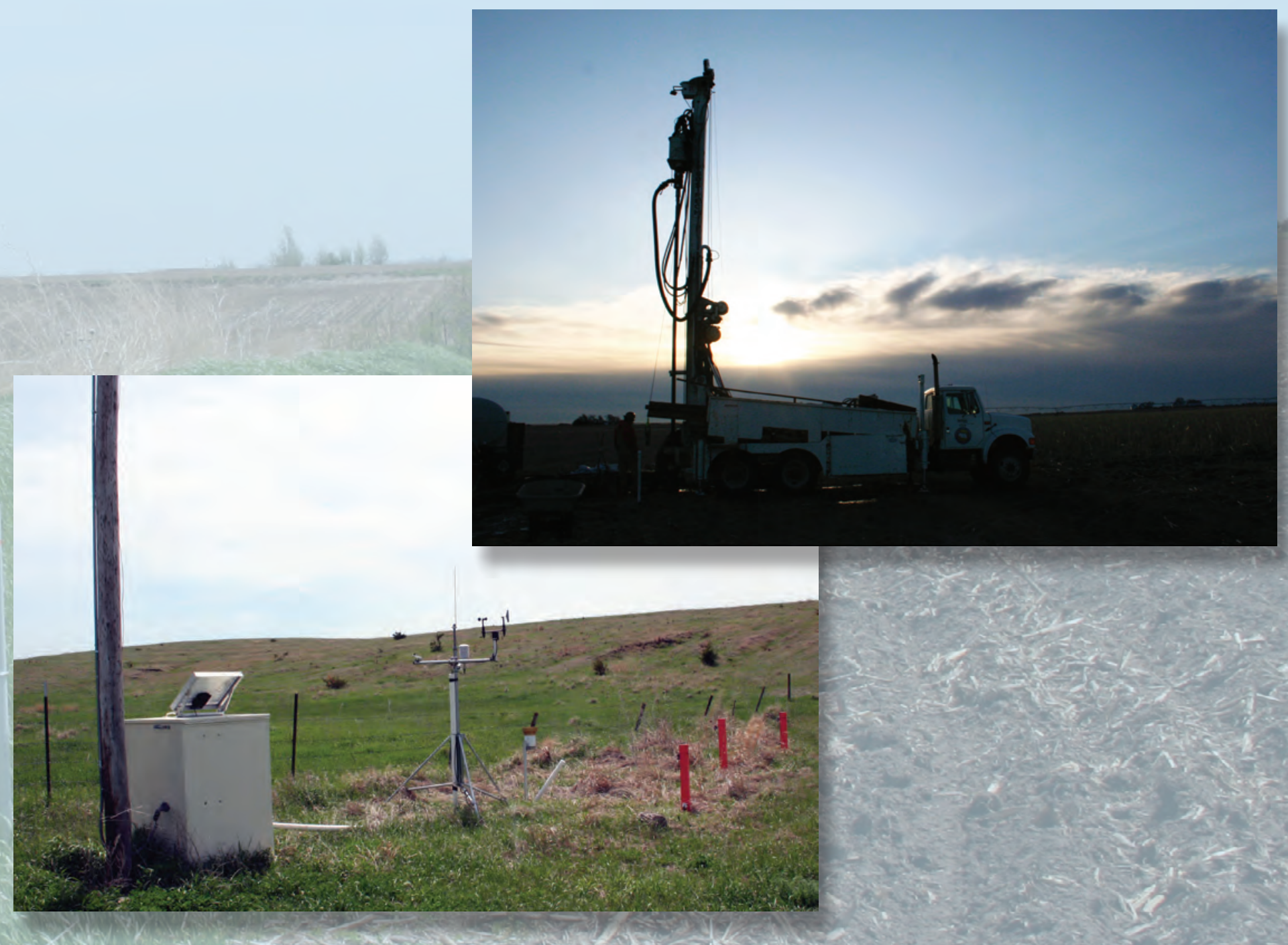

Scientific Investigations Report 2014-5008 
Cover photographs. Top right: Monitoring well installation, site 8. Bottom left: Unsaturated zone site 4, monitoring wells, meteorological instrumentation, and data logger enclosure. Photographs by Greg Steele, U.S. Geological Survey. 


\section{Water Movement through the Unsaturated Zone of the High Plains Aquifer in the Central Platte Natural Resources District, Nebraska, 2008-12}

By Gregory V. Steele, Jason J. Gurdak, and Christopher M. Hobza

Prepared in cooperation with the Central Platte Natural Resources District

Scientific Investigations Report 2014-5008 


\title{
U.S. Department of the Interior SALLY JEWELL, Secretary
}

\section{U.S. Geological Survey Suzette M. Kimball, Acting Director}

\author{
U.S. Geological Survey, Reston, Virginia: 2014
}

For more information on the USGS - the Federal source for science about the Earth, its natural and living resources, natural hazards, and the environment, visit http://www.usgs.gov or call 1-888-ASK-USGS.

For an overview of USGS information products, including maps, imagery, and publications, visit http://www.usgs.gov/pubprod

To order this and other USGS information products, visit http://store.usgs.gov

Any use of trade, firm, or product names is for descriptive purposes only and does not imply endorsement by the U.S. Government.

Although this information product, for the most part, is in the public domain, it also may contain copyrighted materials as noted in the text. Permission to reproduce copyrighted items must be secured from the copyright owner.

Suggested citation:

Steele, G.V., Gurdak, J.J., and Hobza, C.M., 2014, Water movement through the unsaturated zone of the High Plains Aquifer in the Central Platte Natural Resources District, Nebraska, 2008-12: U.S. Geological Survey Scientific Investigations Report 2014-5008, 51 p., plus tables and app., http://dx.doi.org/10.3133/sir20145008.

ISSN 2328-0328 (online) 


\section{Contents}

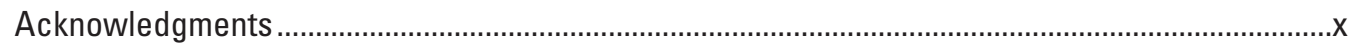

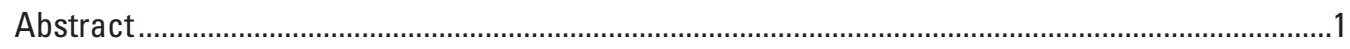

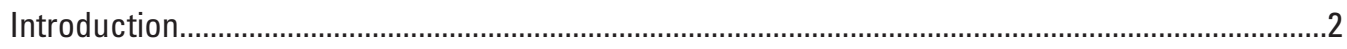

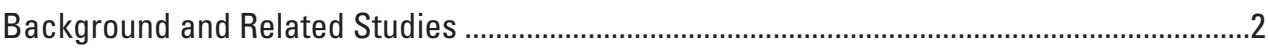

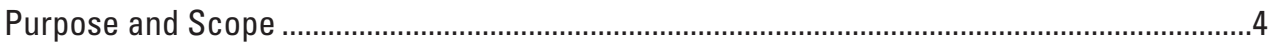

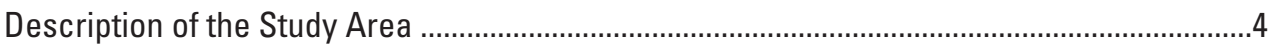

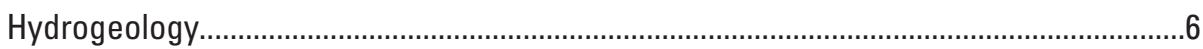

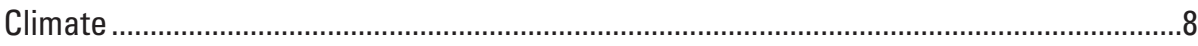

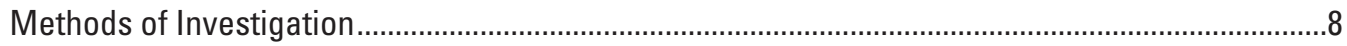

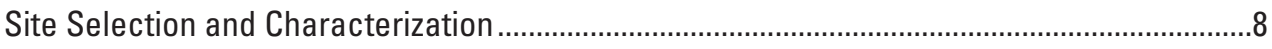

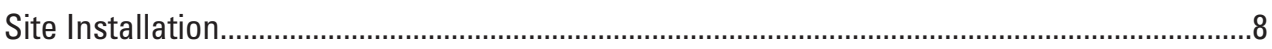

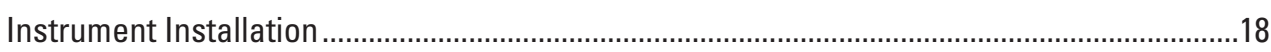

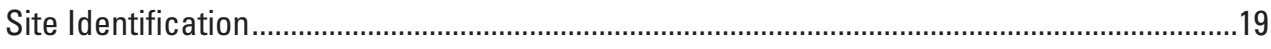

Laboratory and Data Analysis of Sediment Cores ................................................................19

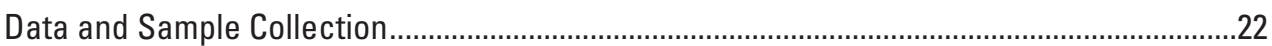

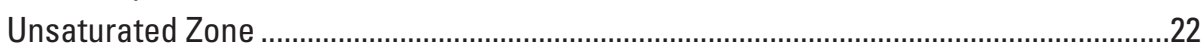

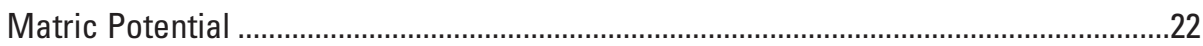

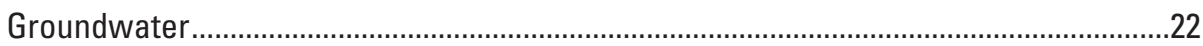

Quality Assurance and Quality Control ................................................................................23

Water Movement through the Unsaturated Zone .............................................................................23

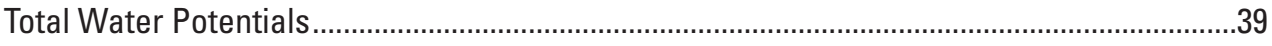

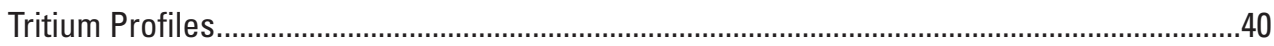

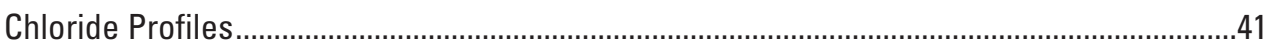

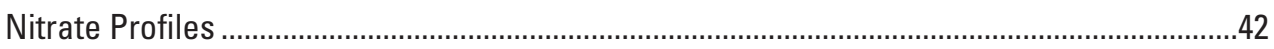

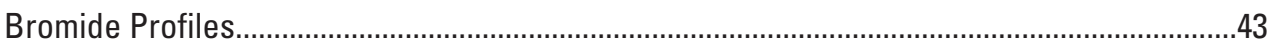

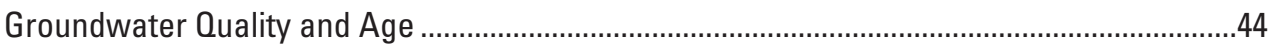

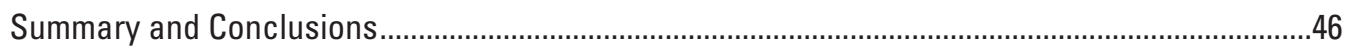

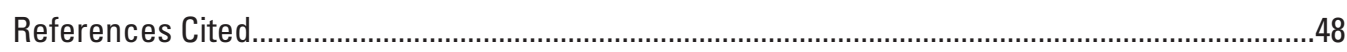

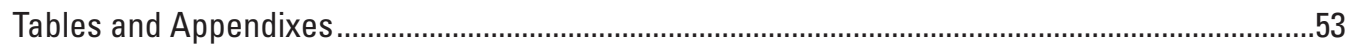




\section{Figures}

1. Map showing location of study area, network of study sites, and Central Platte Natural Resources District, central Nebraska ................................................................

2. Map showing 2005 land-use patterns in the study area ....................................................5

3. Hydrographs of continuous recorders in monitoring wells in the Central Platte Natural Resources District unsaturated-zone network, 2010-12.

4. Diagrams showing lithology of unsaturated-zone sediment, depth of monitoring devices in the unsaturated zone, and depth of well screensin the Central Platte Natural Resources District unsaturated-zone network.

5. Figure showing $A$, photograph of the unsaturated-zone study site 1 and the surrounding rangeland; and $B$, time series of daily precipitation in millimeters and total potential in meters for selected depths below land surface at site 1

6. Figure showing $A$, photograph of the unsaturated-zone study site 2 and the surrounding irrigated corn field; and $B$, time series of daily precipitation in millimeters and total potential in meters for selected depths below land surface at site 2

7. Figure showing $A$, photograph of the unsaturated-zone study site 6 and the surrounding irrigated corn field; and $B$, time series of daily precipitation in millimeters and total potential in meters for selected depths below land surface at site 6

8. Figure showing $A$, photograph of the unsaturated-zone study site 7 and the surrounding irrigated corn field; and $B$, time series of daily precipitation in millimeters and total potential in meters for selected depths below land surface at site 7

9. Figure showing $A$, photograph of the unsaturated-zone study site 8 and the surrounding rangeland; and $B$, time series of daily precipitation in millimeters and total potential in meters for selected depths below land surface at site 8 .

10. Vertical profiles of total potential measured beneath $A$, site $8 ; B$, site $1 ; C$, site 6 ; and $D$, site 2 on selected days, 2010-12.

11. Graphs showing relation between depth below land surface and $A$, tritium concentrations in soil pore water and groundwater; $B$, nitrate concentrations in soil pore water and groundwater; $C$, chloride concentrations in core sections and cuttings and in groundwater; $D$, bromide concentrations in core sections and cuttings; and $E$, lithology, volumetric-water content, and bulk density from samples collected at site 1 in Central Platte Natural Resources District unsaturated-zone network.

12. Graphs showing relation between depth below land surface and $A$, tritium concentrations in soil pore water and groundwater; $B$, nitrate concentrations in soil pore water and groundwater; $C$, chloride concentrations in core sections and cuttings and in groundwater; $D$, bromide concentrations in core sections and cuttings; and $E$, lithology, volumetric-water content, and bulk density from samples collected at site 2 in Central Platte Natural Resources District unsaturated-zone network.

13. Graphs showing relation between depth below land surface and $A$, tritium concentrations in soil pore water and groundwater; $B$, nitrate concentrations in soil pore water and groundwater; $C$, chloride concentrations in core sections and cuttings and in groundwater; $D$, bromide concentrations in core sections and cuttings; and $E$, lithology, volumetric-water content, and bulk density from samples collected at site 3 in Central Platte Natural Resources District unsaturated-zone network. 
14. Graphs showing relation between depth below land surface and $A$, tritium concentrations in soil pore water and groundwater; $B$, nitrate concentrations in soil pore water and groundwater; $C$, chloride concentrations in core sections and cuttings and in groundwater; $D$, bromide concentrations in core sections and cuttings; and $E$, lithology, volumetric-water content, and bulk density from samples collected at site 4 in Central Platte Natural Resources District unsaturated-zone network

15. Graphs showing relation between depth below land surface and $A$, tritium concentrations in soil pore water and groundwater; $B$, nitrate concentrations in soil pore water and groundwater; $C$, chloride concentrations in core sections and cuttings and in groundwater; $D$, bromide concentrations in core sections and cuttings; and $E$, lithology, volumetric-water content, and bulk density from samples collected at site 5 in Central Platte Natural Resources District unsaturated-zone network

16. Graphs showing relation between depth below land surface and $A$, tritium concentrations in soil pore water and groundwater; $B$, nitrate concentrations in soil pore water and groundwater; $C$, chloride concentrations in core sections and cuttings and in groundwater; $D$, bromide concentrations in core sections and cuttings; and $E$, lithology, volumetric-water content, and bulk density from samples collected at site 6 in Central Platte Natural Resources District unsaturated-zone network

17. Graphs showing relation between depth below land surface and $A$, nitrate concentrations in soil pore water and groundwater; $B$, chloride concentrations in core sections and cuttings and in groundwater; $C$, bromide concentrations in core sections and cuttings; and $D$, lithology, volumetric-water content, and bulk density from samples collected at site 7 in Central Platte Natural Resources District unsaturated-zone network

18. Graphs showing relation between depth below land surface and $A$, tritium concentrations in soil pore water and groundwater; $B$, nitrate concentrations in soil pore water and groundwater; $C$, chloride concentrations in core sections and cuttings and in groundwater; $D$, bromide concentrations in core sections and cuttings; and $E$, lithology, volumetric-water content, and bulk density from samples collected at site 8 in Central Platte Natural Resources District unsaturated-zone network 


\section{Tables}

1. Monitoring wells in the Central Platte Natural Resources District unsaturated-zone network, 2008-12.

2. Particle size analyses, percent volumetric water content, bulk density, and percent gravimetric water content determined from selected soil-core samples collected 2008-10, Central Platte Natural Resources District unsaturated-zone network

3. Anion concentrations and volumetric water content in core samples collected spring 2012, Central Platte Natural Resources District unsaturated-zone network .......54

4. Recharge rates as determined from selected methods, Central Platte Natural Resources District unsaturated-zone network, 2008-10

5. Summary statistics for nitrate concentrations in soil pore water from soil samples collected beneath sites 1-8

\section{Appendix Tables}

1-1. Concentrations of selected water-quality constituents from monitoring wells in the Central Platte Natural Resources District unsaturated-zone network, 2009-10......54

1-2. Mean annual precipitation, selected physical characteristics of samples from soil cores used in recharge analyses, selected site characteristics, and concentrations for environmental samples and averaged concentrations of dissolved gases used for groundwater-age modeling. Samples from monitoring wells in the Central Platte Natural Resources District unsaturated-zone network, 2009-10

1-3. Constituents detected in blank samples and comparison of replicate samples from monitoring wells in the Central Platte Natural Resources District unsaturated-zone network, 2009-10 


\section{Conversion Factors}

SI to Inch/Pound

\begin{tabular}{|c|c|c|}
\hline Multiply & By & To obtain \\
\hline \multicolumn{3}{|c|}{ Length } \\
\hline centimeter $(\mathrm{cm})$ & 0.3937 & inch (in.) \\
\hline millimeter (mm) & 0.03937 & inch (in.) \\
\hline micron $(\mu \mathrm{m})$ & 0.00003937 & inch (in.) \\
\hline $\operatorname{meter}(\mathrm{m})$ & 3.281 & foot $(\mathrm{ft})$ \\
\hline kilometer (km) & 0.6214 & mile (mi) \\
\hline \multicolumn{3}{|c|}{ Area } \\
\hline square meter $\left(\mathrm{m}^{2}\right)$ & 0.0002471 & acre \\
\hline hectare (ha) & 2.471 & acre \\
\hline hectare (ha) & 0.003861 & square mile $\left(\mathrm{mi}^{2}\right)$ \\
\hline square kilometer $\left(\mathrm{km}^{2}\right)$ & 0.3861 & square mile $\left(\mathrm{mi}^{2}\right)$ \\
\hline \multicolumn{3}{|c|}{ Volume } \\
\hline milliliter (mL) & 0.001057 & quart (qt) \\
\hline $\operatorname{liter}(\mathrm{L})$ & 1.057 & quart (qt) \\
\hline cubic meter $\left(\mathrm{m}^{3}\right)$ & 264.2 & gallon (gal) \\
\hline \multicolumn{3}{|c|}{ Concentration } \\
\hline micrograms per gram $(\mu \mathrm{g} / \mathrm{g})$ & 0.00000003527 & ounce (oz) \\
\hline grams per cubic meter $\left(\mathrm{g} / \mathrm{m}^{3}\right)$ & 0.00006243 & pounds per cubic foot $\left(\mathrm{lb} / \mathrm{ft}^{3}\right)$ \\
\hline micrograms per liter $(\mu \mathrm{g} / \mathrm{L})$ & 1 & part per billion (ppb) \\
\hline milligrams per liter (mg/L) & 1 & part per million (ppm) \\
\hline \multicolumn{3}{|c|}{ Flow rate } \\
\hline cubic meter per second $\left(\mathrm{m}^{3} / \mathrm{s}\right)$ & 22.83 & million gallons per day $(\mathrm{Mgal} / \mathrm{d})$ \\
\hline liter per minute $(\mathrm{L} / \mathrm{min})$ & 0.2642 & gallon per minute (gal/min) \\
\hline millimeter per year (mm/yr) & 0.03937 & inch per year (in/yr) \\
\hline \multicolumn{3}{|c|}{ Mass } \\
\hline $\operatorname{gram}(\mathrm{g})$ & 0.03527 & ounce, avoirdupois (oz) \\
\hline \multicolumn{3}{|c|}{ Density } \\
\hline grams per cubic centimeter $\left(\mathrm{g} / \mathrm{cm}^{3}\right)$ & 0.03613 & pounds per cubic inch $\left(\mathrm{lb} / \mathrm{in} .^{3}\right)$ \\
\hline \multicolumn{3}{|c|}{ Volumetric content } \\
\hline $\begin{array}{l}\text { cubic centimeter per cubic } \\
\text { centimeter }\left(\mathrm{cm}^{3} / \mathrm{cm}^{3}\right)\end{array}$ & 0.06102 & $\begin{array}{l}\text { cubic inch per cubic } \\
\text { inch }\left(\text { in. }{ }^{3} / \text { in. }^{3}\right)\end{array}$ \\
\hline \multicolumn{3}{|c|}{ Hydraulic conductivity, recharge, flux, or precipitation } \\
\hline meter per second $(\mathrm{m} / \mathrm{s})$ & 3.281 & foot per second \\
\hline meter per day $(\mathrm{m} / \mathrm{d})$ & 3.281 & foot per day $(\mathrm{ft} / \mathrm{d})$ \\
\hline centimeter per year $(\mathrm{cm} / \mathrm{yr})$ & 0.3937 & inch per year (in/yr) \\
\hline grams per square meter $\left(\mathrm{g} / \mathrm{m}^{2}\right)$ & 0.0002048 & pound per square foot $\left(\mathrm{lb} / \mathrm{ft}^{2}\right)$ \\
\hline $\begin{array}{l}\text { grams per square meter per year } \\
\qquad\left(\mathrm{g} / \mathrm{m}^{2} / \mathrm{y}\right)\end{array}$ & 0.0002048 & $\begin{array}{l}\text { pound per square foot per year } \\
\left(\mathrm{lb} / \mathrm{ft}^{2} / \mathrm{yr}\right)\end{array}$ \\
\hline
\end{tabular}




\begin{tabular}{lcl}
\hline \multicolumn{1}{c}{ Multiply } & By & \multicolumn{1}{c}{ To obtain } \\
\hline & Pressure & \\
\hline kilopascal $(\mathrm{kPa})$ & 0.009869 & atmosphere, standard (atm) \\
kilopascal $(\mathrm{kPa})$ & 0.01 & bar \\
kilopascal $(\mathrm{kPa})$ & 1.0 & centibar \\
megapascal $(\mathrm{MPa})$ & 10 & bar \\
megapascal $(\mathrm{MPa})$ & 1,000 & centibar \\
kilopascal $(\mathrm{kPa})$ & 0.2961 & inch of mercury at $60^{\circ} \mathrm{F}($ in $\mathrm{Hg})$ \\
\hline
\end{tabular}

Temperature in degrees Celsius $\left({ }^{\circ} \mathrm{C}\right)$ may be converted to degrees Fahrenheit $\left({ }^{\circ} \mathrm{F}\right)$ as follows: ${ }^{\circ} \mathrm{F}=\left(1.8 \times^{\circ} \mathrm{C}\right)+32$

Temperature in degrees Fahrenheit $\left({ }^{\circ} \mathrm{F}\right)$ may be converted to degrees Celsius $\left({ }^{\circ} \mathrm{C}\right)$ as follows: ${ }^{\circ} \mathrm{C}=\left({ }^{\circ} \mathrm{F}-32\right) / 1.8$

Vertical coordinate information is referenced to the North American Vertical Datum of 1988 (NAVD 88).

Horizontal coordinate information is referenced to the North American Datum of 1983 (NAD 83). Altitude, as used in this report, refers to distance above the vertical datum.

Specific conductance is given in microsiemens per centimeter at 25 degrees Celsius $(\mu \mathrm{S} / \mathrm{cm}$ at $\left.25^{\circ} \mathrm{C}\right)$.

Concentrations of chemical constituents in water are given either in milligrams per liter (mg/L), micrograms per liter $(\mu \mathrm{g} / \mathrm{L})$, tritium units (TU), or tritium unit meter (TU m). 


\section{Symbols}

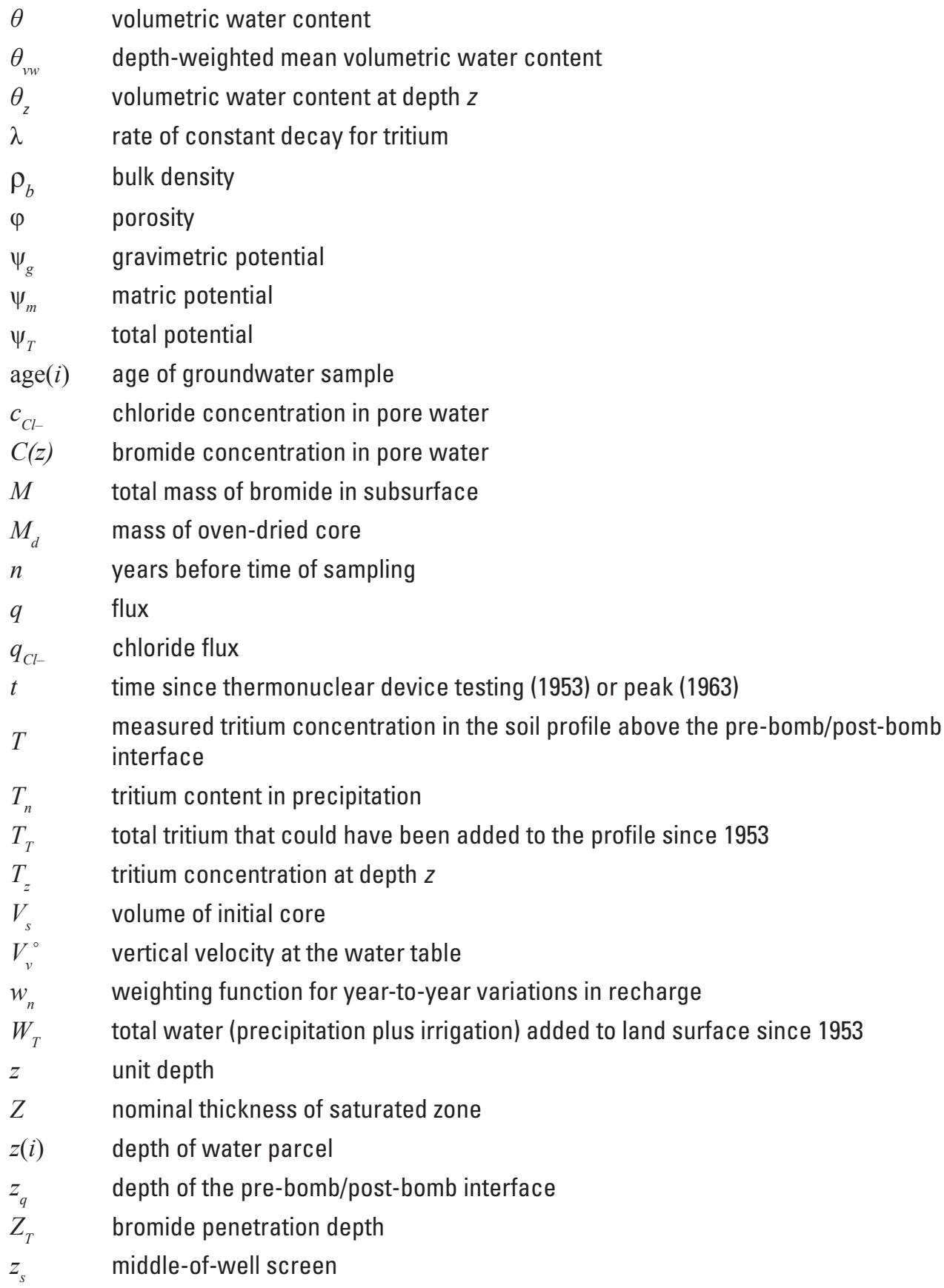




\section{Acknowledgments}

This study conducted in cooperation with the Central Platte Natural Resources District was made possible by support provided by the Nebraska Department of Natural Resources Interrelated Water Management Funds. Acknowledgement is extended to the many people that helped throughout this study. Specifically the authors would like to thank the land owners who graciously provided access to their land and to the Board and staff of the Central Platte Natural Resources District. Special acknowledgement is given to Ron Bishop, Duane Woodward, Dan Clement, and Jesse Mintken of the Central Platte Natural Resources District; to Zachary Lauffenburger of the San Francisco State University; and to Matt Marxsen of the University of Nebraska-Lincoln for their assistance and support. We also thank Jim Goeke and John Gates of the University of Nebraska-Lincoln for their assistance and intellectual input. 


\title{
Water Movement through the Unsaturated Zone of the High Plains Aquifer in the Central Platte Natural Resources District, Nebraska, 2008-12
}

\author{
By Gregory V. Steele, Jason J. Gurdak, and Christopher M. Hobza
}

\section{Abstract}

Uncertainty about the effects of land use and climate on water movement in the unsaturated zone and on groundwater recharge rates can lead to uncertainty in water budgets used for groundwater-flow models. To better understand these effects, a cooperative study between the U.S. Geological Survey and the Central Platte Natural Resources District was initiated in 2007 to determine field-based estimates of recharge rates in selected land-use areas of the Central Platte Natural Resources District in Nebraska. Measured total water potential and unsaturated-zone profiles of tritium, chloride, nitrate as nitrogen, and bromide, along with groundwater-age dates, were used to evaluate water movement in the unsaturated zone and groundwater recharge rates in the central Platte River study area. Eight study sites represented an east-west precipitation contrast across the study area-four beneath groundwater-irrigated cropland (sites 2, 5, and 6 were irrigated corn and site 7 was irrigated alfalfa/corn rotation), three beneath rangeland (sites 1, 4, and 8), and one beneath nonirrigated cropland, or dryland (site 3).

Measurements of transient vertical gradients in total water potential indicated that periodic wetting fronts reached greater mean maximum depths beneath the irrigated sites than beneath the rangeland sites, in part, because of the presence of greater and constant antecedent moisture. Beneath the rangeland sites, greater temporal variation in antecedent moisture and total water potential existed and was, in part, likely a result of local precipitation and evapotranspiration. Moreover, greater variability was noticed in the total water potential profiles beneath the western sites than the corresponding eastern sites, which was attributed to less mean annual precipitation in the west.

The depth of the peak post-bomb tritium concentration or the interface between the pre-bomb/post-bomb tritium, along with a tritium mass balance, within sampled soil profiles were used to estimate water fluxes in the unsaturated zone at three of the eight study sites: site 2 (irrigated), site 3 (dryland), and site 8 (rangeland). Estimates for recharge were about 68 millimeters per year $[(\mathrm{mm} / \mathrm{yr})$, post-bomb peak], 133 to $159 \mathrm{~mm} / \mathrm{yr}$ (tritium interface), and $137 \mathrm{~mm} / \mathrm{yr}$ (mass balance) at site 2 (irrigated); about $63 \mathrm{~mm} / \mathrm{yr}$ (tritium interface) and $12 \mathrm{~mm} / \mathrm{yr}$ (mass balance) at site 3 (dryland); and about $53 \mathrm{~mm} / \mathrm{yr}$ (tritium interface) and $10 \mathrm{~mm} / \mathrm{yr}$ (mass balance) at site 8 (rangeland). Recharge values from the mass balance at site 2 were more than an order of magnitude greater than recharge values at site 3 , suggesting irrigation is an important control on water movement through the unsaturated zone. For the remaining five sites, the post-bomb tritium had flushed through the system and recharge was considered modern (within 10 years of sampling).

The chloride mass-balance method was used to determine water fluxes below the root zone (less than 2 meters below land surface) at the rangeland sites: sites 1, 4, and 8. At these rangeland sites, water fluxes ranged from 1.8 to $96 \mathrm{~mm} / \mathrm{yr}$ at site $1,1.1$ to $9.6 \mathrm{~mm} / \mathrm{yr}$ at site 4 , and 1.1 to $68 \mathrm{~mm} / \mathrm{yr}$ at site 8 , with mean rates of $21,4.3$, and $13 \mathrm{~mm} / \mathrm{yr}$, respectively. Site 1 had a greater mean water flux, which was consistent with the greater precipitation in the east than at site 8 in the west. Chloride mass balance was not calculated at the irrigated and dryland sites because of uncertainty about additional sources of chloride.

Concentrations of nitrate as nitrogen in pore water in the unsaturated zone were larger beneath the irrigated and dryland (agricultural) sites compared with the rangeland sites. The larger concentrations at the agricultural sites are consistent with the application of nitrogen fertilizer at the agricultural sites and no substantial accumulation at the rangeland sites. The shape of the nitrate as nitrogen and chloride concentration profiles at site 1 (rangeland) indicate a reasonably larger and more consistent water flux in the UZ than beneath the other two rangeland sites (sites 4 or 8 ). Excluding site 7, the general shape of the nitrate as nitrogen profiles was similar beneath the agricultural sites and supports the estimates of water movement and recharge rates determined from the tritium and chloride methods.

Movement of bromide through the unsaturated zone indicated greater water fluxes are found beneath irrigated lands than beneath rangeland. Bromide profiles in the unsaturated zone, determined from center of mass and peak displacement methods, document water fluxes ranged from 58 to $394 \mathrm{~mm} / \mathrm{yr}$ 
beneath irrigated sites and 9 to $201 \mathrm{~mm} / \mathrm{yr}$ beneath rangeland sites. Water-flux estimates from the potassium bromide tests at most sites did not represent overall recharge rates because the bromide remained primarily in the root zone.

Apparent groundwater age was used to determine the groundwater residence time at the eight sites and to estimate recharge rates. Groundwater ages in the study area ranged from old water (defined here as groundwater that was recharged more than 50 years ago) to modern (defined here as groundwater that has recharged within the past 10 years). Groundwater ages indicated that the shallow monitoring wells generally had younger residence times, whereas the deeper monitoring wells generally had the older residence times. Groundwater dates from the shallowest monitoring wells were used to determine recharge rates at the water table. These rates generally were similar to recharge rates determined from tritium and chloride mass-balance methods. Groundwater recharge rates generally increased with well depth, and the deeper monitoring wells likely do not represent local recharge conditions but recharge from a regional flow system that receives recharge from distant sources.

Overall, these data generally indicate that water movement within the unsaturated zone primarily is affected by spatial contrasts in mean annual precipitation and by the land use or land cover. The eight unsaturated-zone sites each generated unique, valuable datasets that likely will improve the understanding of water movement and recharge rates in the central Platte River valley.

\section{Introduction}

This section describes background and previous studies, the purpose and scope of this report, and a description of the study area. Discussion of related studies in the "Background and Related Studies" section primarily is restricted to an overview of a study that initiated this study.

\section{Background and Related Studies}

In 1997, Colorado, Nebraska, Wyoming, and the U.S. Department of the Interior entered into an Interagency Cooperative Agreement (ICA) partnership aimed at addressing issues regarding endangered species (such as the whooping crane, piping plover, least tern, and pallid sturgeon) in the Platte River Basin (Platte River Cooperative Hydrology Study, 1998). Critical to the ICA is the provision for maintenance of streamflows in the Platte River and the mitigation of new depletions in the central Platte River area. As a direct result of the ICA, State and local agencies created a Cooperative Hydrology Study [(COHYST), Platte River Cooperative Hydrology Study, 1998] of the Platte River Basin (not shown) of Nebraska upstream from Columbus, Nebraska (Nebr.)

(fig. 1). The purpose of COHYST was to assist Nebraska in complying with the ICA (Luckey and Cannia, 2006) through the integrated management of groundwater and surface water. The objectives of COHYST were to develop databases and tools to assist Nebraska in meeting its obligations for streamflow, to analyze proposed activities to improve streamflows for endangered and threatened species, to assist Natural Resources Districts (NRDs) with regulation and management of groundwater, and to provide a basis for establishing and implementing Nebraska policies and procedures governing groundwater and surface-water resources.

The initial activity of COHYST was the creation of a 75,890-square-kilometer $\left(\mathrm{km}^{2}\right)$ numerical groundwater-flow model of the Platte River Basin from about 9.7 kilometer $(\mathrm{km})$ west of the Wyoming-Nebraska boundary to upstream from Columbus, Nebr. The COHYST groundwater model consisted of three separate groundwater-modeling units - eastern, central, and western. That part of the Platte River Basin within the Central Platte Natural Resources District (CPNRD), in southcentral Nebraska, predominantly lies in COHYST's eastern modeling unit (Peterson, 2007).

A primary water-balance component for input to groundwater-flow models is groundwater recharge (herein referred to as "recharge"). Recharge, in a broad sense, can be defined as the movement of water into an aquifer from any direction (Scanlon and others, 2002). Freeze and Cherry (1979, p. 211) define recharge as "the entry into the saturated zone of water made available at the water-table surface..." The current study (2013) focused on recharge as the vertical or downward movement of water through the unsaturated zone (UZ) and across the water table. Understanding this movement of water within the $\mathrm{UZ}$ is crucial to characterizing recharge in the CPNRD area and for COHYST.

In semihumid to semiarid regions such as the CPNRD, most precipitation that infiltrates the soil does not become recharge; rather, the water is stored in the soil profile and ultimately returned to the atmosphere by evaporation or transpiration (Todd and Mays, 2005). However, some of this water does flow to the saturated zone to become recharge. Estimating the amount of water that becomes recharge is challenging because there are many complexities in the movement of water from the soil surface through the UZ and then into the saturated zone. Furthermore, these complexities can be compounded by such factors as precipitation, vegetation, geology, and topography. Temporally, groundwater recharge in humid areas happens almost continuously through the UZ; however, in more arid environments, evapotranspiration processes generally exceed precipitation, recharge is less, and "groundwater recharge tends to decrease with increasing aridity" (Gee and Hillel, 1988, p. 256).

In many cases, as for this report, recharge takes place by water movement from the land surface through the UZ. As a result, in groundwater-flow modeling, estimated recharge typically is adjusted as a residual component. Therefore, true recharge values often are not directly measured in the field. Many times, recharge values are determined through literature search, through calibration of groundwater-flow models, through modeling using a net irrigation requirement or recharge models, or through any combination of these. 


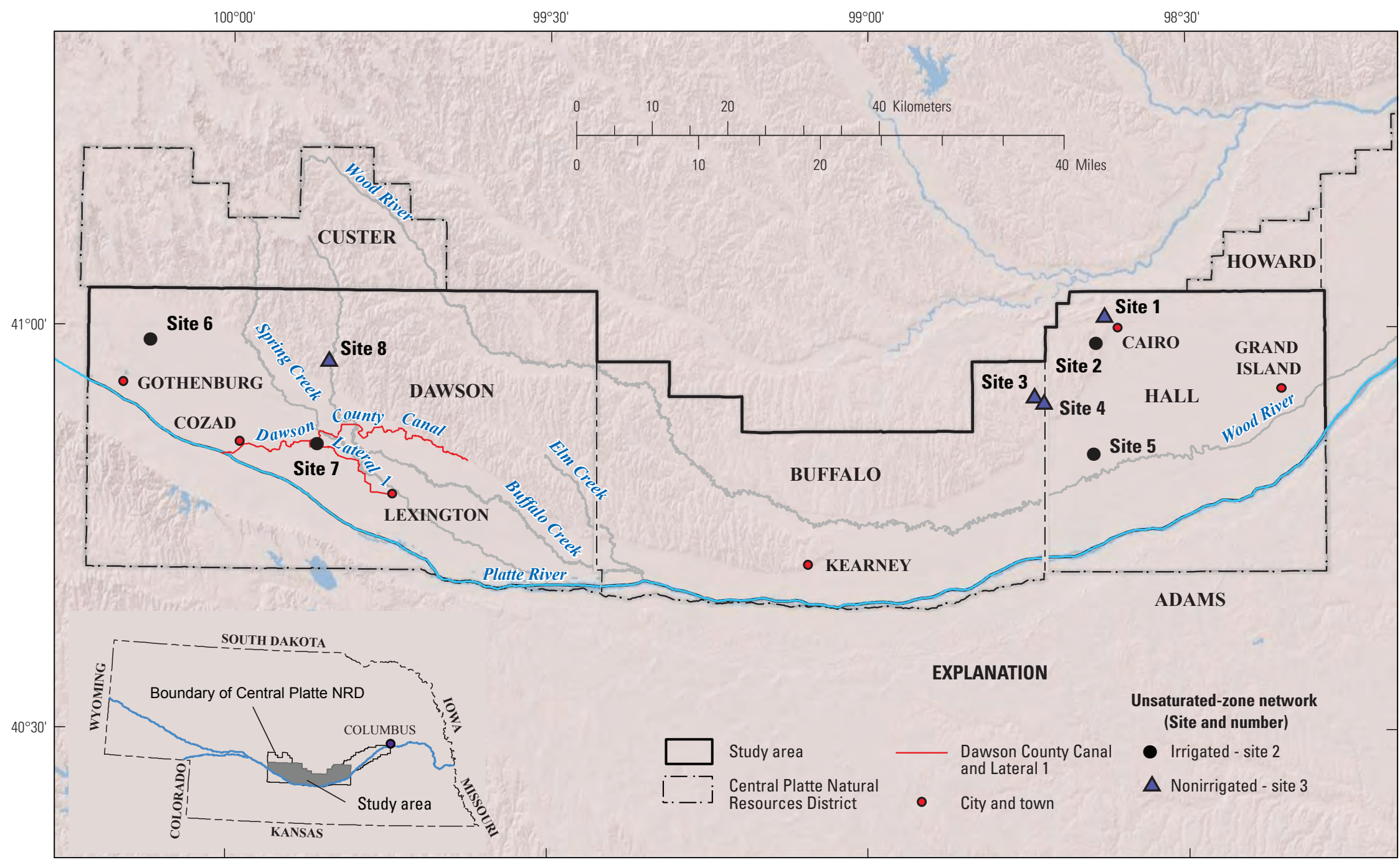

Base from U.S. Geological Survey digital data 30-meter resolution

Universal Transverse Mercator projection, Zone 14 North

Horizontal coordinate information is referenced to the

North American Datum of 1983 (NAD 83)

Figure 1. Location of study area, network of study sites, and Central Platte Natural Resources District (NRD), central Nebraska 
Understanding the effects of land use and climate on water movement in the $\mathrm{UZ}$ and on recharge rates is critically important to develop appropriate management and sustainability plans for groundwater resources in the CPNRD and other parts of the High Plains aquifer. In particular, field-based estimates of recharge rates under selected land-use types and along the east-west precipitation gradients in the CPNRD can be used to better calibrate and validate the COHYST groundwater model or other models. Calibrated and validated groundwater models are important tools used to help maintain critical flows as outlined in the Cooperative Agreement partnership.

In 2007, the U.S Geological Survey (USGS), in cooperation with the CPNRD, began a study to determine recharge rates across the CPNRD. Eight study sites (fig. 1) represented selected land-use areas across the CPNRD. The site selection and capabilities of the eight study sites were modeled after nine existing sites in the USGS High Plains Unsaturated-Zone Research Network (HPUZRN) (McMahon and others, 2007; Gurdak and others, 2009). The HPUZRN was designed to determine recharge and chemical transport through and storage in the UZ beneath important land-use settings across the High Plains aquifer (McMahon and others, 2006; Gurdak and others, 2007). Similarly, the eight study sites in the CPNRD unsaturated-zone network were designed to determine recharge and chemical transport through the UZ of the High Plains aquifer in the CPNRD. Consequently, all UZ research sites established for this study have been added to the HPUZRN.

\section{Purpose and Scope}

The purpose of this report is to describe the results of a study to determine recharge and water movement through the UZ underlying selected land-use types in the CPNRD. This report describes the methods used to select and instrument the sites, methods, and analytes used to determine water movement and recharge rates [such as chloride $\left(\mathrm{Cl}^{-}\right)$, nitrate as nitrogen $\left(\mathrm{NO}_{3}{ }^{-}\right.$as $\left.\mathrm{N}\right)$ (hereinafter referred to as $\mathrm{NO}_{3}{ }^{-}$), and tritium $\left({ }^{3} \mathrm{H}\right)$; methods and analytes used to determine apparent or modeled groundwater age (hereinafter referred to as "groundwater age"); and the methods used to determine the physical properties of the UZ. This report presents findings from soil analyses on two conservative anions, bromide $\left(\mathrm{Br}^{-}\right)$ and $\mathrm{Cl}^{-}$, as well as $\mathrm{NO}_{3}{ }^{-}$. This report also presents precipitation data collected on site or in the study area.

\section{Description of the Study Area}

The approximately $2,600-\mathrm{km}^{2}$ study area lies in the Highland Plains Section of the Great Plains Province (Fenneman, 1946) and wholly within Buffalo, Dawson, and Hall Counties in the CPNRD (fig. 1). The study area stretches from east of Grand Island (eastern boundary of Hall County line) to west of Gothenburg (western boundary of Dawson County). The Dawson and Hall County lines, as well as the CPNRD boundary in Buffalo County, form the northern boundary of the study area. The Platte River forms the southern boundary of the study area. The landscape of the study area predominantly is dissected upland areas north of the Platte River valley and lowlands within the Platte River valley. Soils in the study area generally are well-drained, although generally wetland areas are located within about $8 \mathrm{~km}$ from the Platte River (such as in Dawson County) (Natural Resources Conservation Service, 1974, 1978, and 2004a; Peterson, 2007).

Principal cities within the study area include (from largest to smallest) Grand Island, Kearney, Lexington, Cozad, and Gothenburg (U.S. Census Bureau, 2013). Agriculture, and thus groundwater availability, generally dominates the socioeconomics of the study area as well as the CPNRD. Groundwater serves as the primary source for irrigation throughout much of the CPNRD. Secondary sources for irrigation generally include surface-water canal systems, which also can serve as important sources of groundwater recharge (Peterson, 2007; Carney, 2008).

Land use within the study area primarily is agricultural (fig. 2). Total irrigated land in the study area in 2005, by county, was about 64,600 hectares (ha) in Buffalo County; about 72,000 ha in Dawson County; and about 56,000 ha in Hall County (Center for Advanced Land Management Information Technologies, 2010). Dryland (nonirrigated cropland or pasture) hectares in the study area in 2005 were about 7,000 ha in Buffalo County; about 11,700 ha in Dawson County; and about 3,400 ha in Hall County (Center for Advanced Land Management Information Technologies, 2010).

The approximate distribution of land use in the central Platte River valley includes 39.2 percent for irrigated corn and soybeans, 40.4 percent for rangeland or pasture, 8.3 percent for dryland crops, 3.6 percent for irrigated alfalfa, and 8.5 percent as other (fig. 2; Center for Advanced Land Management Information Technologies, 2010). Center-pivot or gravityirrigated corn and soybean production dominates all irrigation use in the central Platte River valley. Some surface-water irrigation takes place in the study area but mostly is limited to the western part of the CPNRD. Surface-water canals include Dawson County Canal located near site 7 (fig. 1) and the Cozad, Gothenburg, Kearney, Thirty-Mile, Orchard Alfalfa, and Elm Creek Canals (not shown on any maps) (Peterson, 2007).

The primary surface-water feature in the study area is the Platte River. Wood River, Buffalo Creek, and Spring Creek are the largest tributaries of the Platte River in the study area. Smaller tributaries, such as Elm Creek, are present in the study area, but their discharges typically are much smaller than Wood River and many are not gaged.

The aforementioned streams and canals are prominent throughout the CPNRD, and locally, canals recharge the groundwater system (Peterson, 2007). Most surface-water systems in the CPNRD are distant from the UZ study sites and did not directly affect results of the recharge analyses. The Dawson County Canal, however, is about 400 meters (m) south of site 7 in Dawson County, and recharge from surface water is evident in recorded local groundwater levels. 


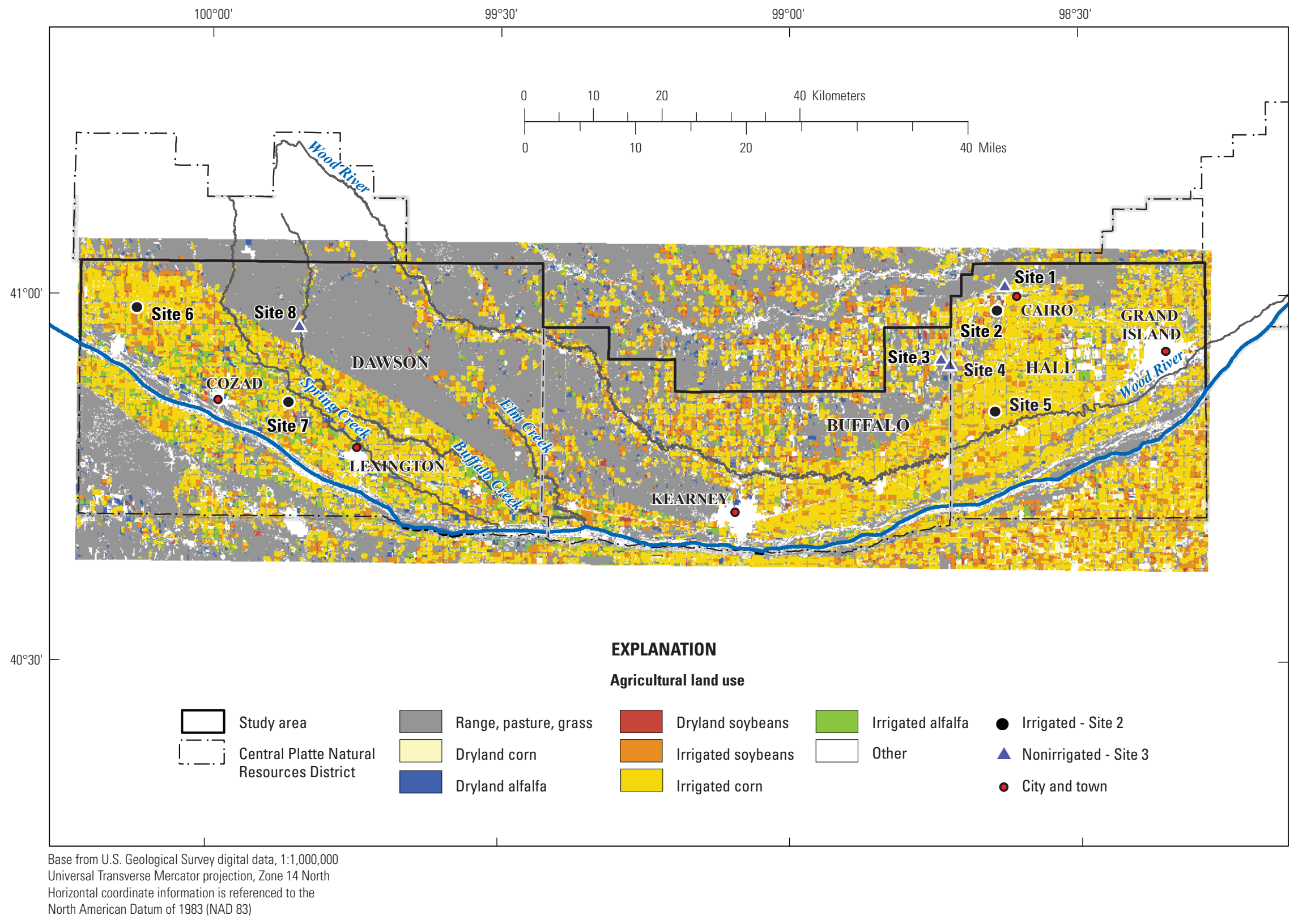

Figure 2. 2005 land-use patterns in the study area. Modified from Center for Advanced Land Management Information Technologies (2010). 
In the CPNRD, the thickness of the UZ typically can vary from less than $1 \mathrm{~m}$ near the Platte River to more than $45 \mathrm{~m}$ in the loess-covered uplands above the Platte River valley. Thickness of UZ deposits dictates the proximity of saturated subsurface deposits to the land surface, and groundwater recharge rates can be affected by UZ thickness. Depending on the composition of the hydrogeologic deposits, thin UZ deposits can allow water from the surface to recharge in a matter of hours or days (Steele, 1994), whereas for thicker deposits water typically takes longer to move through the UZ and become groundwater recharge.

\section{Hydrogeology}

The hydrogeology of the study area ranges from unconsolidated Quaternary deposits to unconsolidated to semiconsolidated Tertiary deposits. Saturated Quaternary deposits, a heterogeneous mixture of silt, clay, sand, and gravel, serve as the primary aquifer in the CPNRD and compose the substrate for all surficial aquifers within the study area. Quaternary deposits predominantly are unconfined systems within the Pleistocene alluvium of the Platte River valley, and also can occur as loess of Pleistocene to Holocene age and blanketing upland areas, or as eolian sand comprising localized unconfined upland surficial aquifers in Holocene dune sand (Peterson, 2007) present in the northeastern part of the study area. In the upland areas, localized sand and gravel deposits may be found. Hereinafter, this report defines surficial aquifers as any unconfined Quaternary aquifer located in either the uplands or the Platte River valley and aforementioned tributaries incising the upland areas such as Wood River valley.

Total thickness of the Quaternary deposits can vary substantially in the study area. In the Platte River valley, extensive sand and gravel deposits with interlayered silt and clay overlie the unconsolidated to semiconsolidated aquifer in the Ogallala Group that varies in depth from less than $25 \mathrm{~m}$ to more than $70 \mathrm{~m}$ (Dreeszen and others, 1973). In the eastern part of Hall County, the Ogallala Group is absent (Dreeszen, 1999) and Quaternary deposits directly overlie Cretaceous deposits. In the uplands, loess deposits with thickness generally from 30 to $40 \mathrm{~m}$ are the predominant Quaternary deposit. The uplands loess deposits largely are unsaturated and overlie the Ogallala Group. The Ogallala Group, whose thickness can exceed $100 \mathrm{~m}$, serves as the primary aquifer outside of the Platte River valley and makes up the semiconsolidated Tertiary aquifer underlying most of the study area. Locally, unmapped deposits of the White River Group of Tertiary age may exist, but typically these fine-grained deposits do not yield sufficient water to sustain high-capacity wells (Gutentag and others, 1984). Hereinafter, this report will use "Ogallala aquifer" to refer to all Tertiary aquifers within the study area.

Groundwater levels in the study area vary spatially and temporally. Depths to groundwater in lowland areas generally range from less than $1 \mathrm{~m}$ near the major rivers to more than $10 \mathrm{~m}$ near the edges of the Platte River valley bottomland. Depths to groundwater in the Platte River terraces and upland areas can be much greater. In these areas, groundwater levels typically range from about $16 \mathrm{~m}$ on the terraces to between 20 and $60 \mathrm{~m}$ in the upland areas. The large range in depth to groundwater primarily reflects the presence of topographic relief - draws and river valleys that incised into the uplands. Wells within draws and low-order stream valleys will have shallow depths to groundwater (generally $20 \mathrm{~m}$ or more) than wells in upland areas (Steele, 1994).

Locally, based on data collected from wells in CPNRD unsaturated-zone network [USGS National Water Information System (NWIS), http://waterdata.usgs.gov/nwis], groundwater levels also vary seasonally with the largest depths to groundwater generally occurring in the July-to-September timeframe (fig. 3), which is generally about 1 to 2 months after the onset of the irrigation season. The larger depths to groundwater during July to September generally is the rule only at sites that are distant from surface-water canals, such as study sites $1-6$ and site 8 . Near some canals, groundwater levels reach their largest depths near the onset of surface-water diversions into canals for irrigation, typically at the end of April to the beginning of May. Leakage from nearby canals can locally recharge the groundwater system and bring groundwater levels nearer to the surface. When the canals stop operating, groundwater levels tend to decline to postirrigation levels and thence return to their lowest levels in spring (fig. 3, site 7). The amount of surface water available for diversion determines how much recharge is available to the groundwater. During the drought of 2012, less surface water was available for the nearby canal. Consequently, groundwater levels at site 7 were not able to recharge to levels of the previous summer.

The large number of irrigation wells throughout the study area attest to the productivity of the principal aquifers. Wells located (or screened) in the surficial aquifer are capable of producing in excess of 3,700 liters per minute ( $\mathrm{L} / \mathrm{min}$ ) (Waite and others, 1949). Wells screened in the Ogallala aquifer can yield about the same volume of water as the shallower Quaternary wells, but the Ogallala wells need longer screened intervals (60 to $90 \mathrm{~m}$ ) to maintain similar yields. Consequently, if shallow surficial aquifers are available and productive, producers will install production wells in the shallow deposits to economize installation and pumping costs (McGuire and others, 2003).

The surficial aquifers are the primary aquifers largely because of their widespread distribution, shallow depths, and their ability to yield sufficient groundwater supplies to highcapacity wells. In addition, these aquifers are unconfined systems and, as stated previously, they can be located outside the Platte River valley. Aquifer tests conducted (McGuire and Kilpatrick, 1998; Chen and others, 2003) or reanalyzed (Chen, 1998) within the CPNRD indicate the hydraulic conductivity of the surficial aquifers in the CPNRD typically ranges from $1.1 \times 10^{-3}$ to $1.6 \times 10^{-3}$ meters per second $(\mathrm{m} / \mathrm{s})$. The USGS completed a series of 96-hour constant-discharge aquifer tests at two locations in the surficial and Ogallala aquifers within the study area in 2008 and 2010. The composite analyses of these aquifer tests indicated the hydraulic conductivity ranges from $1.0 \times 10^{-3}$ to $8.5 \times 10^{-4} \mathrm{~m} / \mathrm{s}$ for the surficial aquifer and $3.5 \times 10^{-5}$ to $3.9 \times 10^{-5} \mathrm{~m} / \mathrm{s}$ for the Ogallala aquifer (Irons and others, 2012). 


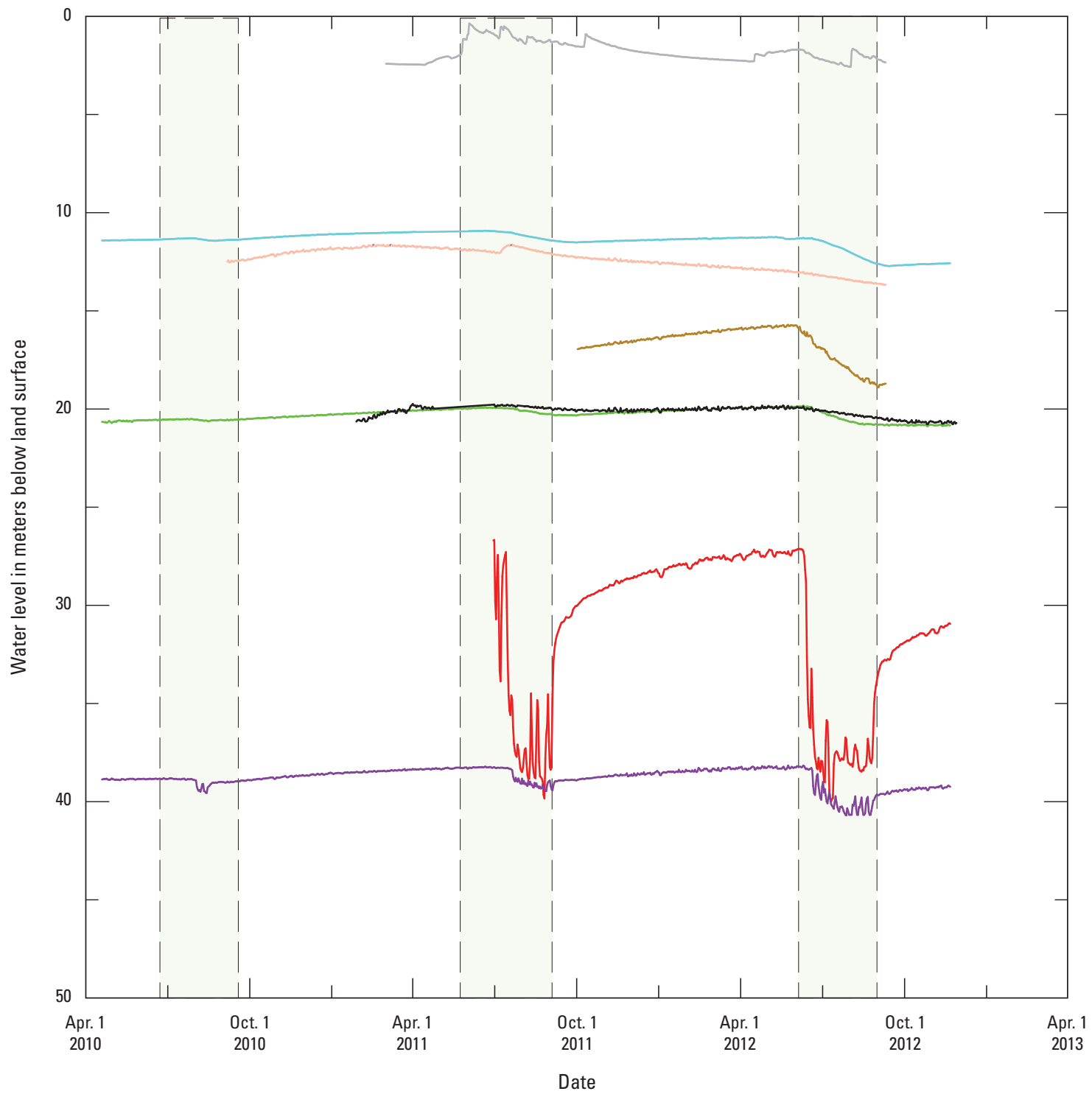

EXPLANATION

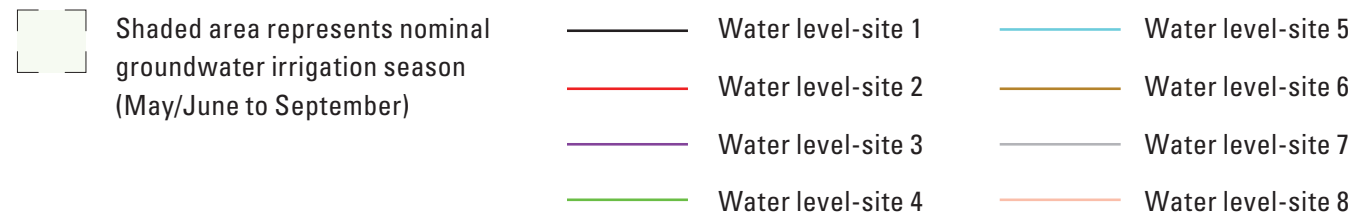

Figure 3. Hydrographs of continuous recorders in monitoring wells in the Central Platte Natural Resources District unsaturated-zone network, 2010-12. 
Water Movement through the Unsaturated Zone of the High Plains Aquifer in the CPNRD, Nebraska, 2008-12

\section{Climate}

The climate is characterized by cold winters and warm summers typical of mid-continental locations (Carney, 2008). Mean monthly temperatures during 1895 to 2010 ranged from -3.7 degrees Celsius $\left({ }^{\circ} \mathrm{C}\right)$ in January to $24.3{ }^{\circ} \mathrm{C}$ in July at Gothenburg, Nebr. Mean monthly temperatures during 1939 to 2009 were similar at Grand Island, Nebr., and ranged from $-5.0^{\circ} \mathrm{C}$ in January to $24.9{ }^{\circ} \mathrm{C}$ in July (National Oceanic and Atmospheric Administration, 2013).

Precipitation is variable from east to west across the CPNRD with more arid conditions in the west, on average. Precipitation averaged 55.6 centimeters per year $(\mathrm{cm} / \mathrm{yr})$ from 1931 to 2012 in western Dawson County at Gothenburg, Nebr. (National Climate Data Center station identification 253365), and $62.2 \mathrm{~cm} / \mathrm{yr}$ from 1939 to 2009 near Grand Island, Nebr. (National Climate Data Center station identification 253395) in the eastern part of the study area (National Oceanic and Atmospheric Administration, 2013). Approximately 65 percent of the precipitation is received during the first 5 months of the growing season (April through August). Low humidity, abundant sunshine, and persistent winds contribute to reasonably high rates of evaporation (Gutentag and others, 1984).

\section{Methods of Investigation}

The following section describes the methods used for this investigation. Specifically, this section describes the selection and characterization of the sites, drilling and site installation, instrumentation, site identification, laboratory and data analysis, and unsaturated-zone and saturated-zone sampling.

\section{Site Selection and Characterization}

The study sites were selected to determine if the spatial patterns in recharge rates primarily are controlled by spatial patterns in mean annual precipitation and land use or land cover. To a lesser extent, sites were selected to establish additional contrasts based on the texture of sediments in the UZ (such as loess or alluvium) and depth to water (such as upland areas). Eight sites (fig. 1) for the CPNRD unsaturatedzone network were installed across the east-west precipitation contrast in the study area and under various land-use settings. Control sites were located on rangeland areas that were considered to never have been used for agriculture.

To examine precipitation effects on recharge rates five eastern sites were established in the CPNRD where annual total precipitation generally exceeds that of the three western sites. Long term daily precipitation data for all eight sites were collected from either the Grand Island Central Nebraska Regional Airport (National Climate Data Center station identification 253395) or Gothenburg, Nebr. (National Climate Data Center station identification 253365). These two sites are part of the National Oceanic and Atmospheric
Administration (NOAA) National Climatic Data Center (NCDC) (National Oceanic and Atmospheric Administration, 2013).

The minimal distance between the two groups of sites (eastern and western) was about $90 \mathrm{~km}\left(-98^{\circ} 44^{\prime}\right.$ to $-99^{\circ} 50^{\prime}$ longitude, respectively), but all eight sites were at similar latitude, within an 11-minute latitudinal range (40 $50^{\prime}$ to $\left.41^{\circ} 01^{\prime}\right)$. As a result, an east-west precipitation contrast was the only precipitation contrast for the study.

Primary criteria for site selections were land use and land cover. To investigate land-use/land-cover effects on recharge rates, the eight sites were selected from specifically targeted land-use or land-cover types (irrigated cropland, dryland crops, and rangeland; fig. 2). Most sites were placed on upland areas where depth to groundwater was greater than $16 \mathrm{~m}$.

\section{Site Installation}

From 2008 to 2010, eight UZ study sites were installed in the study area (fig. 1) - two in 2008, three in 2009, and three in 2010. To collect water samples from the UZ and the saturated zone, each site was equipped with multiple suction lysimeters and shallow wells. Depth to groundwater dictated the number of suction lysimeters at a site. Sites 1-6 and 8 all contained three lysimeters at various depths, site 7 contained two lysimeters because of a shallow water table.

The clustered monitoring wells at each site typically consisted of three wells installed to assess vertical gradients in groundwater flow and chemistry. In April 2008, the first two sites (sites 1 and 2) initially contained a single shallow monitoring well. During November 2008, two additional monitoring wells per site were installed to determine vertical groundwater-chemistry and groundwater-age profiles near the top of the aquifer. The remaining six sites (sites 3-8) were designed with two to three clustered monitoring wells (each well in a separate borehole). Site 5 was designed with the installation of a single monitoring well to augment the existing nested wells (all wells in a single borehole). Site 8 had two monitoring wells because the surficial aquifer was reasonably thin. Site and well names, along with water levels, screen intervals, and location coordinates are located in table 1. Altogether, 23 of the 24 monitoring wells were used for the study; the shallowest nested well at site 5 was mostly dry during data collection and was not used during the study period.

A hollow-stem auger was used to core a single 15-centimeter $(\mathrm{cm})$ borehole to a depth of about $2 \mathrm{~m}$ below the top of the aquifer at sites overlying surficial aquifers and to about $30 \mathrm{~m}$ at upland sites overlying the Ogallala aquifer. Concurrently, continuous soil-core samples were collected using a split-spoon core barrel containing two 9-cm x 0.76-m tenite cellulose acetate butyrate $(\mathrm{CAB})$ tubes or sleeves. The $0.76-\mathrm{m}$ $\mathrm{CAB}$ sleeves were used to retain and return soil samples to the land surface for lithologic description (fig. 4) and sectioning for laboratory analysis of physical and chemical properties of the sediment. Each CAB sleeve that contained enough 
Table 1. Monitoring wells in the Central Platte Natural Resources District unsaturated-zone network, $2008-12$.

[all distances in meters; ID, identifier or identification number; altitude above the North American Vertical Datum of 1988; latitude and longitude are referenced to the North American Datum of 1983]

\begin{tabular}{|c|c|c|c|c|c|c|c|c|c|}
\hline \multirow[t]{2}{*}{ Site } & \multirow{2}{*}{$\begin{array}{c}\text { Site } \\
\text { number }\end{array}$} & \multirow{2}{*}{$\begin{array}{l}\text { U.S. Geological } \\
\text { Survey } \\
\text { site ID }\end{array}$} & \multirow[t]{2}{*}{ Local ID } & \multirow{2}{*}{$\begin{array}{c}\text { Water level, } \\
\text { below land } \\
\text { surface, } \\
\text { April } 2010\end{array}$} & \multicolumn{2}{|c|}{$\begin{array}{c}\text { Screened } \\
\text { interval, below } \\
\text { land surface }\end{array}$} & \multirow[t]{2}{*}{ Altitude } & \multirow[t]{2}{*}{ Latitude } & \multirow[t]{2}{*}{ Longitude } \\
\hline & & & & & Top & Bottom & & & \\
\hline \multirow{3}{*}{ Site 1} & Site $1-26$ & 410102098374201 & $12 \mathrm{~N} 12 \mathrm{~W} 11 \mathrm{DDDD} 1$ & 20.22 & 24.1 & 25.6 & 606.6 & $41^{\circ} 01^{\prime} 02.5^{\prime \prime}$ & $-098^{\circ} 37^{\prime} 41.7^{\prime \prime}$ \\
\hline & Site $1-30$ & 410102098374202 & 12N 12W11DDDD2 & 19.84 & 29.0 & 30.5 & 606.6 & $41^{\circ} 01^{\prime} 02.5^{\prime \prime}$ & $-098^{\circ} 37^{\prime} 41.7^{\prime \prime}$ \\
\hline & Site $1-35$ & 410102098374203 & 12N 12W11DDDD3 & 19.87 & 33.5 & 35.1 & 606.6 & $41^{\circ} 01^{\prime} 02.5^{\prime \prime}$ & $-098^{\circ} 37^{\prime} 41.7^{\prime \prime}$ \\
\hline \multirow{3}{*}{ Site 2} & Site $2-52$ & 405855098383001 & $12 \mathrm{~N} 12 \mathrm{~W} 26 \mathrm{CBAA} 1$ & 27.66 & 50.3 & 51.8 & 618.1 & $40^{\circ} 58^{\prime} 55.4^{\prime \prime}$ & $-098^{\circ} 38^{\prime} 30.1^{\prime \prime}$ \\
\hline & Site 2-61 & 405855098383002 & $12 \mathrm{~N} 12 \mathrm{~W} 26 \mathrm{CBAA} 2$ & 27.58 & 59.4 & 61.0 & 618.1 & $40^{\circ} 58^{\prime} 55.3^{\prime \prime}$ & $-098^{\circ} 38^{\prime} 30.0^{\prime \prime}$ \\
\hline & Site $2-70$ & 405855098383003 & $12 \mathrm{~N} 12 \mathrm{~W} 26 \mathrm{CBAA} 3$ & 27.53 & 68.6 & 70.1 & 618.1 & $40^{\circ} 58^{\prime} 55.4^{\prime \prime}$ & $-098^{\circ} 38^{\prime} 29.6^{\prime \prime}$ \\
\hline \multirow{3}{*}{ Site 3} & Site 3-52 & 405503098441801 & $11 \mathrm{~N} 13 \mathrm{~W} 13 \mathrm{CCCD} 1$ & 38.87 & 50.3 & 51.8 & 646.8 & $40^{\circ} 55^{\prime} 02.7 ’$ & $-098^{\circ} 44^{\prime} 18.2^{\prime \prime}$ \\
\hline & Site 3-59 & 405503098441802 & $11 \mathrm{~N} 13 \mathrm{~W} 13 \mathrm{CCCD} 2$ & 38.85 & 57.3 & 58.8 & 646.8 & $40^{\circ} 55^{\prime} 02.7^{\prime \prime}$ & $-098^{\circ} 44^{\prime} 18.2^{\prime \prime}$ \\
\hline & Site 3-64 & 405503098441803 & $11 \mathrm{~N} 13 \mathrm{~W} 13 \mathrm{CCCD} 3$ & 38.80 & 62.8 & 64.3 & 646.8 & $40^{\circ} 55^{\prime} 02.7 ’$ & $-098^{\circ} 44^{\prime} 18.2^{\prime \prime}$ \\
\hline \multirow{3}{*}{ Site 4} & Site 4-29 & 405435098432601 & $11 \mathrm{~N}$ 13W24ADDC1 & 20.64 & 25.9 & 29.0 & 624.8 & $40^{\circ} 54^{\prime} 34.9^{\prime \prime}$ & $-098^{\circ} 43^{\prime} 26.4^{\prime \prime}$ \\
\hline & Site 4-35 & 405435098432602 & $11 \mathrm{~N} 13 \mathrm{~W} 24 \mathrm{ADDC} 2$ & 20.75 & 33.5 & 35.1 & 624.8 & $40^{\circ} 54^{\prime} 34.9^{\prime \prime}$ & $-098^{\circ} 43^{\prime} 26.4^{\prime \prime}$ \\
\hline & Site 4-44 & 405435098432603 & $11 \mathrm{~N} 13 \mathrm{~W} 24 \mathrm{ADDC} 3$ & 20.71 & 41.1 & 44.2 & 624.8 & $40^{\circ} 54^{\prime} 34.9^{\prime \prime}$ & $-098^{\circ} 43^{\prime} 26.4^{\prime \prime}$ \\
\hline \multirow{4}{*}{ Site 5} & Site 5-11 & 405040098384501 & $10 \mathrm{~N} 12 \mathrm{~W} 11 \mathrm{CCCC} 1$ & 11.01 & 10.7 & 11.3 & 605.6 & $40^{\circ} 50^{\prime} 39.7^{\prime \prime}$ & $-098^{\circ} 38^{\prime} 44.6^{\prime \prime}$ \\
\hline & Site $5-14$ & 405040098384502 & $10 \mathrm{~N} 12 \mathrm{~W} 11 \mathrm{CCCC} 2$ & 11.01 & 13.1 & 13.7 & 605.6 & $40^{\circ} 50^{\prime} 39.7 \prime$ & $-098^{\circ} 38^{\prime} 44.6^{\prime \prime}$ \\
\hline & Site $5-17$ & 405040098384503 & $10 \mathrm{~N} 12 \mathrm{~W} 11 \mathrm{CCCC} 3$ & 11.41 & 15.2 & 16.8 & 605.6 & $40^{\circ} 50^{\prime} 39.9^{\prime \prime}$ & $-098^{\circ} 38^{\prime} 44.3^{\prime \prime}$ \\
\hline & Site $5-20$ & 405040098384504 & $10 \mathrm{~N} 12 \mathrm{~W} 11 \mathrm{CCCC} 4$ & 11.06 & 18.9 & 19.5 & 605.6 & $40^{\circ} 50^{\prime} 39.7^{\prime \prime}$ & $-098^{\circ} 38^{\prime} 44.6^{\prime \prime}$ \\
\hline \multirow{3}{*}{ Site 6} & Site 6-23 & 405855100073901 & $12 \mathrm{~N} 25 \mathrm{~W} 25 \mathrm{CBBB} 1$ & 17.69 & 21.3 & 22.9 & 803.1 & $40^{\circ} 58^{\prime} 54.7^{\prime \prime}$ & $-100^{\circ} 07^{\prime} 38.8^{\prime \prime}$ \\
\hline & Site 6-27 & 405855100073902 & $12 \mathrm{~N} 25 \mathrm{~W} 25 \mathrm{CBBB} 2$ & 17.57 & 25.3 & 26.8 & 803.1 & $40^{\circ} 58^{\prime} 54.8^{\prime \prime}$ & $-100^{\circ} 07^{\prime} 38.9^{\prime \prime}$ \\
\hline & Site 6-30 & 405855100073903 & $12 \mathrm{~N} 25 \mathrm{~W} 25 \mathrm{CBBB} 3$ & 17.59 & 29.0 & 30.5 & 803.1 & $40^{\circ} 58^{\prime} 54.8^{\prime \prime}$ & $-100^{\circ} 07^{\prime} 39.1^{\prime \prime}$ \\
\hline \multirow{3}{*}{ Site 7} & Site 7-6 & 405118099514901 & $10 \mathrm{~N} 22 \mathrm{~W} 8 \mathrm{BCBB} 1$ & 1.31 & 4.6 & 6.1 & 751.0 & $40^{\circ} 51^{\prime} 18.3^{\prime \prime}$ & $-099^{\circ} 51^{\prime} 48.9^{\prime \prime}$ \\
\hline & Site 7-11 & 405118099514902 & $10 \mathrm{~N} 22 \mathrm{~W} 8 \mathrm{BCBB} 2$ & 1.31 & 9.1 & 10.7 & 751.0 & $40^{\circ} 51^{\prime} 18.3^{\prime \prime}$ & $-099^{\circ} 51^{\prime} 48.9^{\prime \prime}$ \\
\hline & Site $7-14$ & 405118099514903 & $10 \mathrm{~N} 22 \mathrm{~W} 8 \mathrm{BCBB} 3$ & 1.30 & 12.8 & 14.3 & 751.0 & $40^{\circ} 51^{\prime} 18.3 ”$ & $-099^{\circ} 51^{\prime} 48.9^{\prime \prime}$ \\
\hline \multirow{2}{*}{ Site 8} & Site $8-18$ & 405738099504501 & $11 \mathrm{~N} 22 \mathrm{~W} 4 \mathrm{BBBB} 1$ & 14.23 & 16.5 & 18.0 & 777.8 & $40^{\circ} 57^{\prime} 38.3^{\prime \prime}$ & $-099^{\circ} 50^{\prime} 44.8^{\prime \prime}$ \\
\hline & Site $8-24$ & 405738099504502 & $11 \mathrm{~N} 22 \mathrm{~W} 4 \mathrm{BBBB} 2$ & 14.52 & 21.3 & 24.4 & 777.8 & $40^{\circ} 57^{\prime} 38.3^{\prime \prime}$ & $-099^{\circ} 50^{\prime} 45.0 "$ \\
\hline
\end{tabular}




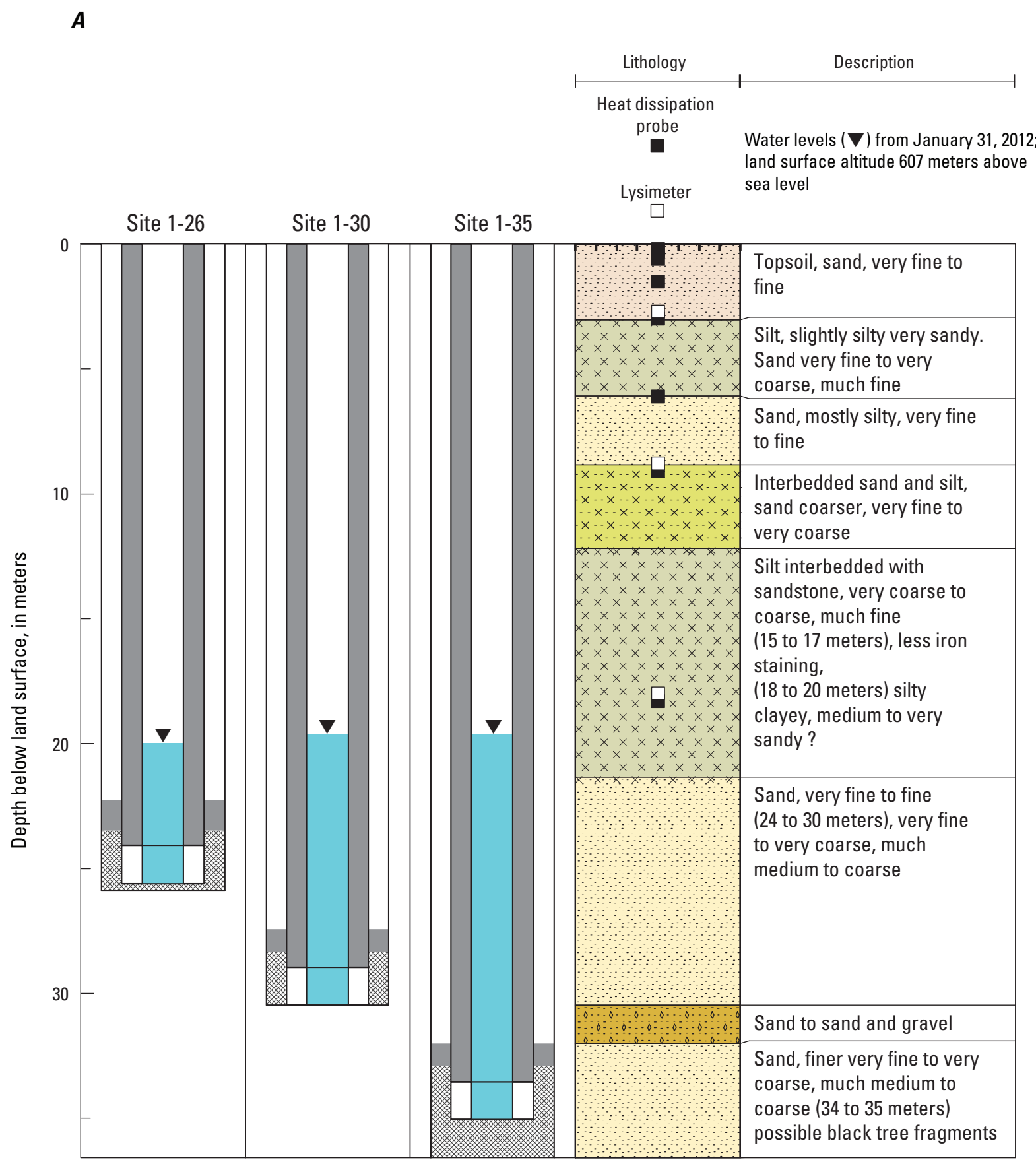

Figure 4. Lithology of unsaturated-zone sediment, depth of monitoring devices in the unsaturated zone, and depth of well screens at $A$, site $1 ; B$, site $2 ; C$, site $3 ; D$, site $4 ; E$, site $5 ; F$, site $6 ; G$, site 7 ; and $H$, site 8 in the Central Platte Natural Resources District unsaturated-zone network. 


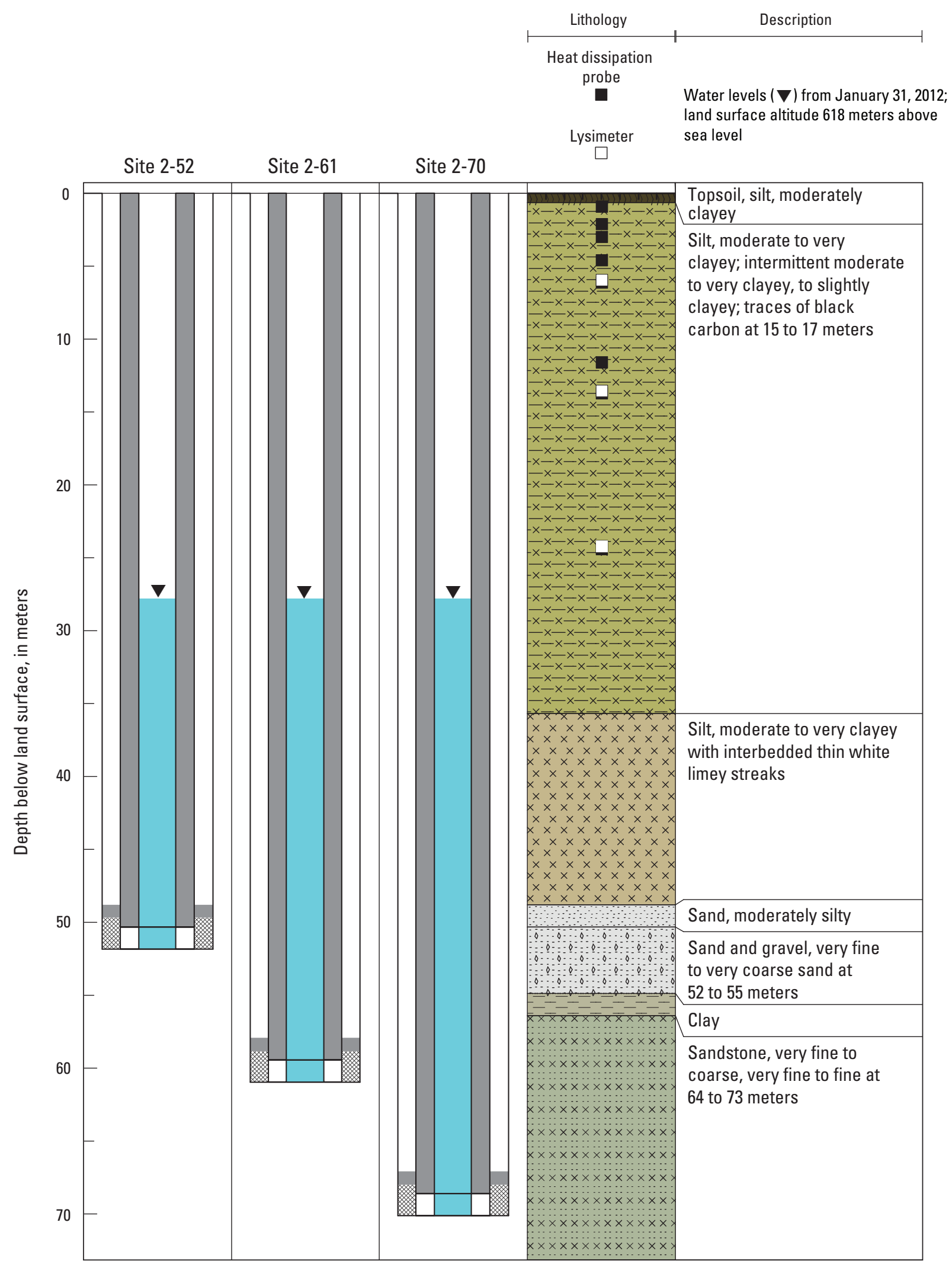

Figure 4. Lithology of unsaturated-zone sediment, depth of monitoring devices in the unsaturated zone, and depth of well screens at $A$, site $1 ; B$, site $2 ; C$, site $3 ; D$, site $4 ; E$, site $5 ; F$, site $6 ; G$, site 7 ; and $H$, site 8 in the Central Platte Natural Resources District unsaturated-zone network.-Continued 
C

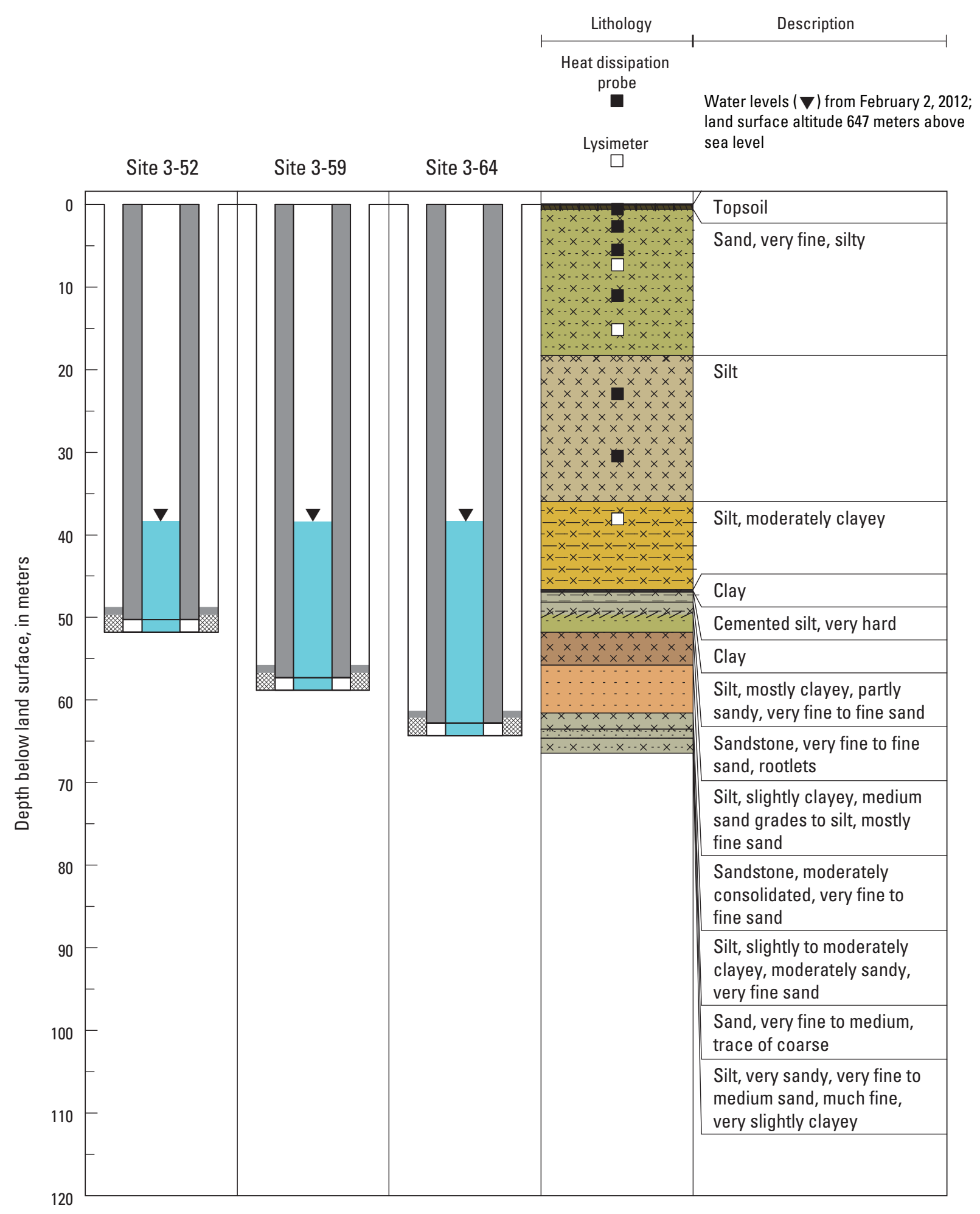

Figure 4. Lithology of unsaturated-zone sediment, depth of monitoring devices in the unsaturated zone, and depth of well screens at $A$, site $1 ; B$, site $2 ; C$, site $3 ; D$, site $4 ; E$, site $5 ; F$, site $6 ; G$, site 7 ; and $H$, site 8 in the Central Platte Natural Resources District unsaturated-zone network.-Continued 
D

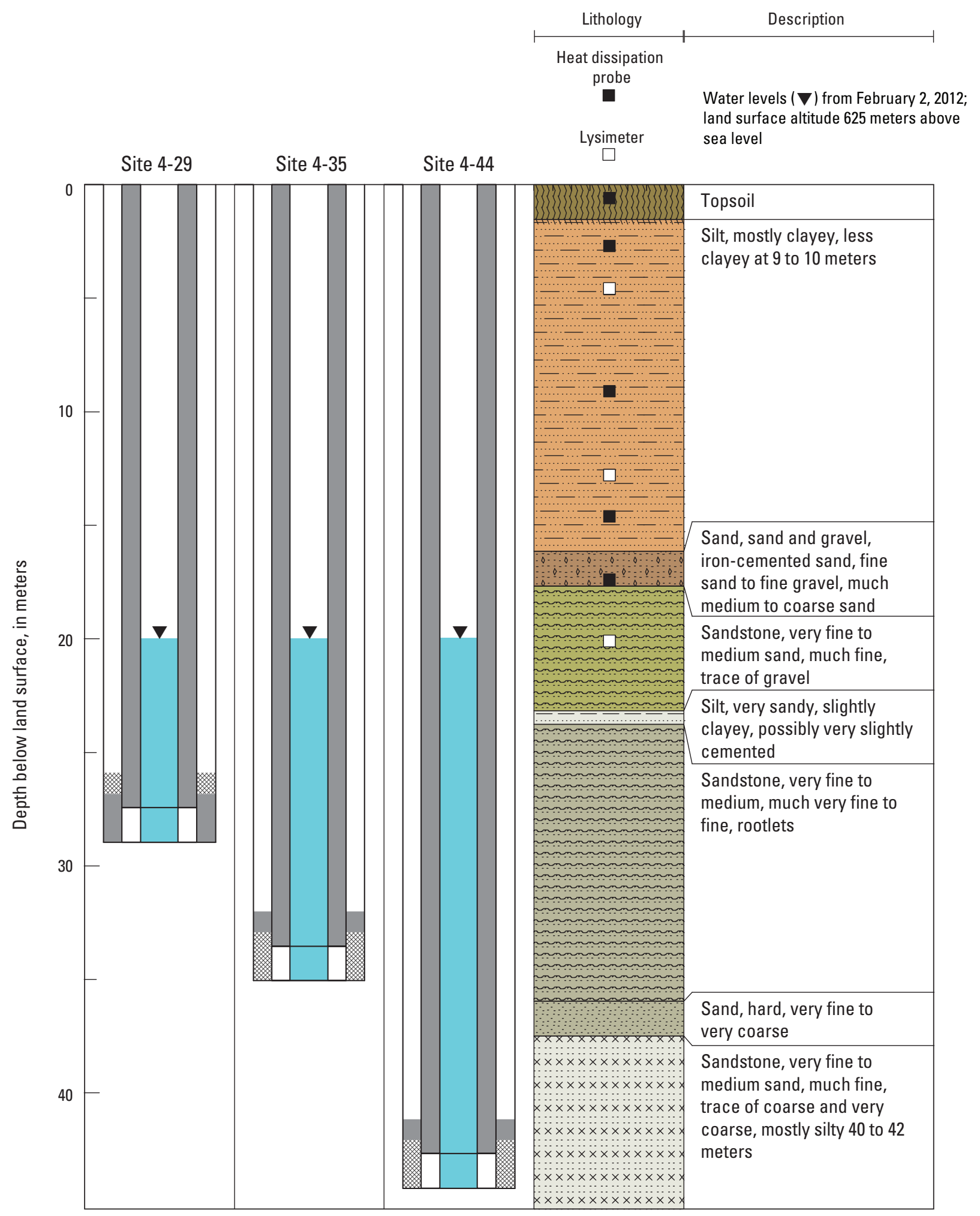

Figure 4. Lithology of unsaturated-zone sediment, depth of monitoring devices in the unsaturated zone, and depth of well screens at $A$, site $1 ; B$, site $2 ; C$, site $3 ; D$, site 4 ; $E$, site $5 ; F$, site $6 ; G$, site 7 ; and $H$, site 8 in the Central Platte Natural Resources District unsaturated-zone network.-Continued 


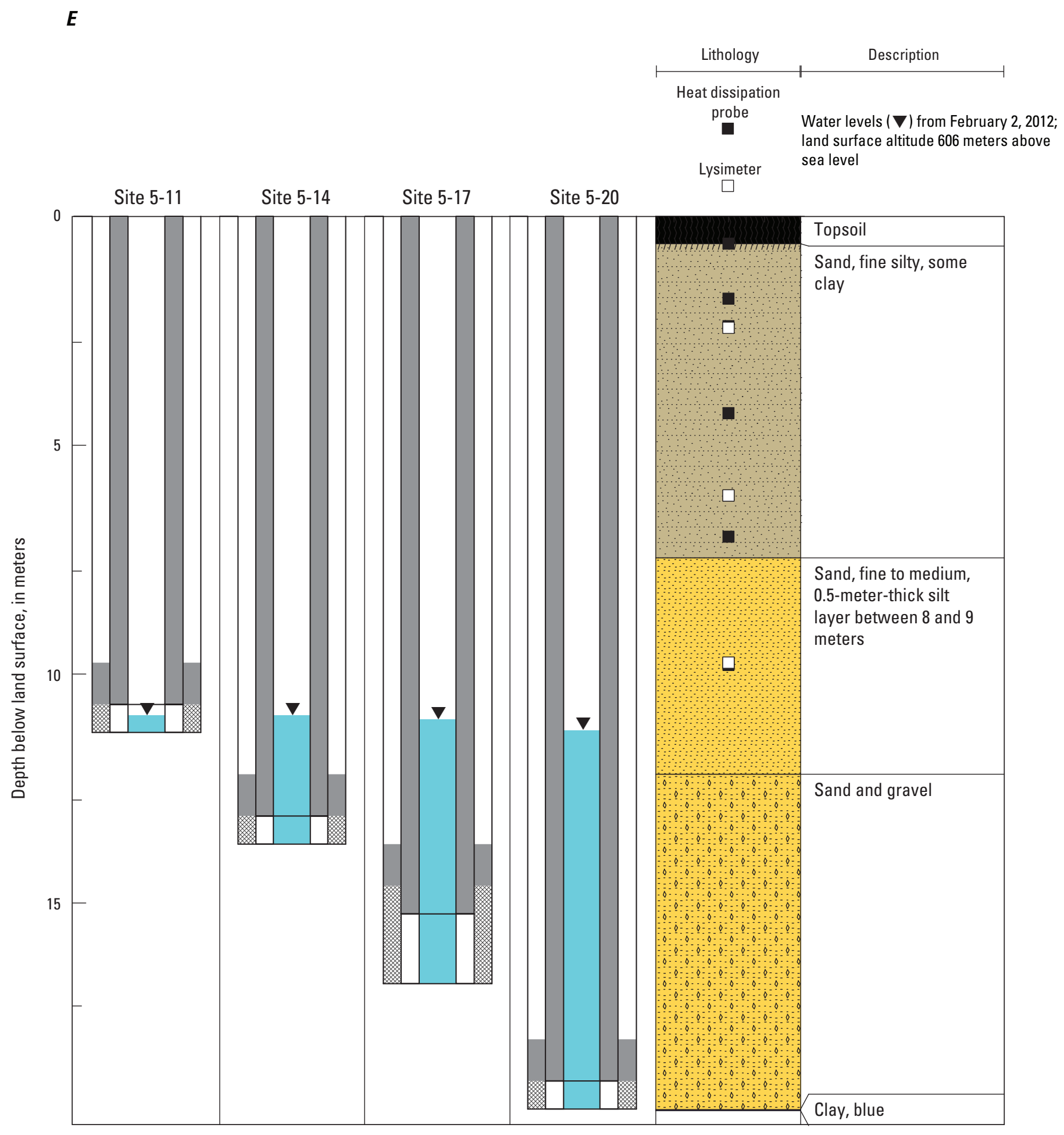

Figure 4. Lithology of unsaturated-zone sediment, depth of monitoring devices in the unsaturated zone, and depth of well screens at $A$, site $1 ; B$, site $2 ; C$, site $3 ; D$, site $4 ; E$, site $5 ; F$, site 6 ; $G$, site 7 ; and $H$, site 8 in the Central Platte Natural Resources District unsaturated-zone network.-Continued 


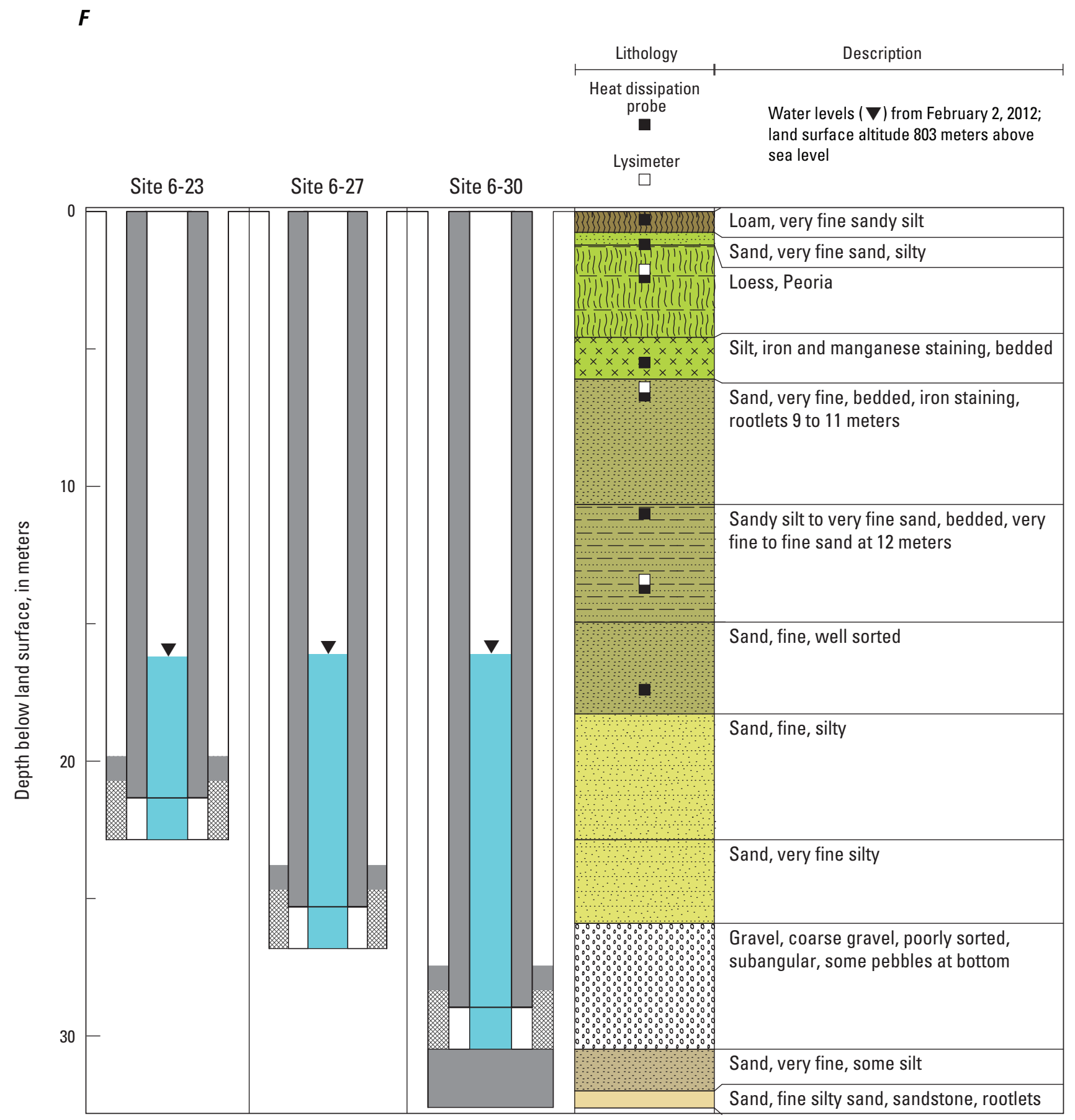

Figure 4. Lithology of unsaturated-zone sediment, depth of monitoring devices in the unsaturated zone, and depth of well screens at $A$, site $1 ; B$, site $2 ; C$, site $3 ; D$, site 4 ; $E$, site $5 ; F$, site 6 ; $G$, site 7 ; and $H$, site 8 in the Central Platte Natural Resources District unsaturated-zone network.-Continued 
$\boldsymbol{G}$

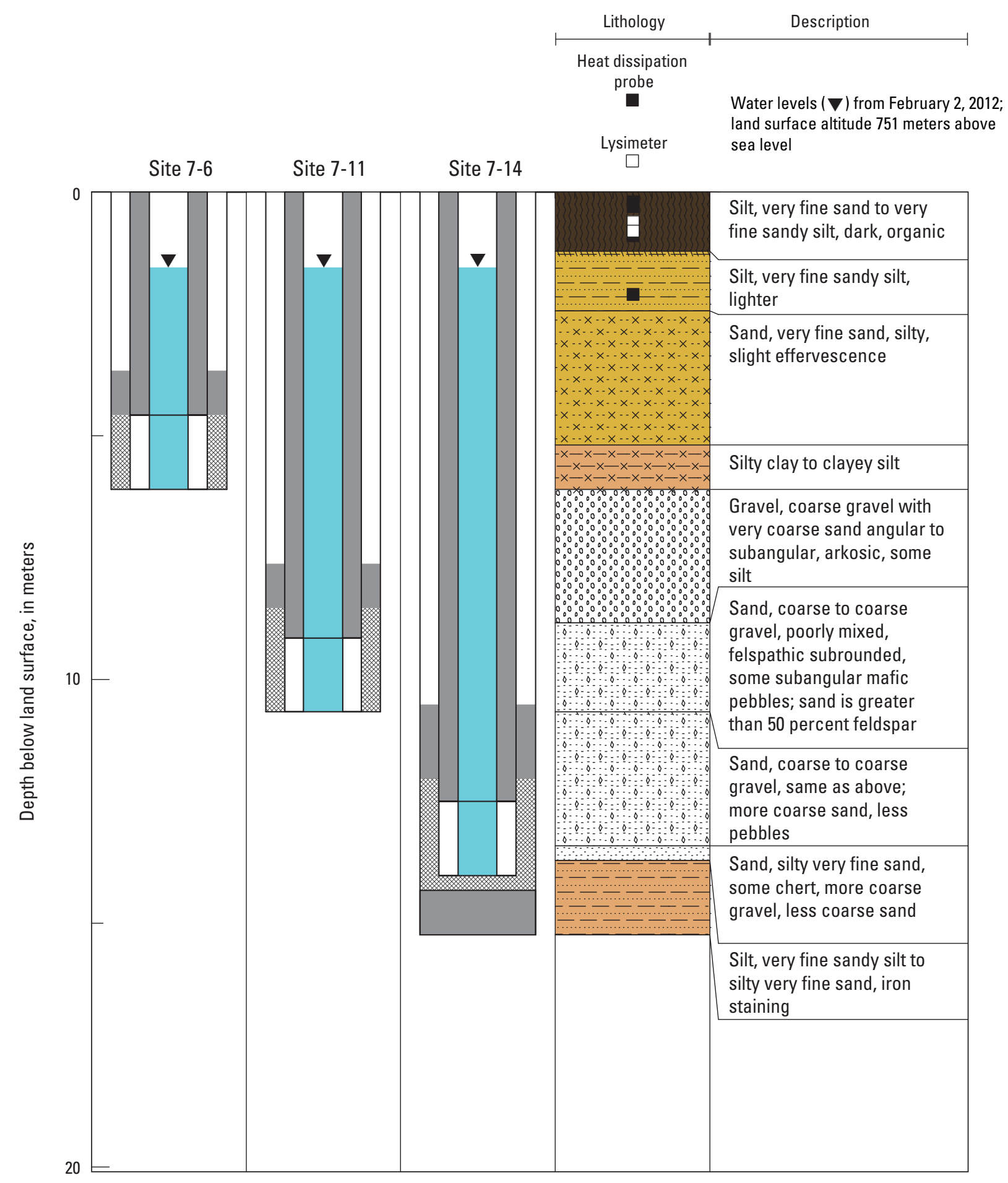

Figure 4. Lithology of unsaturated-zone sediment, depth of monitoring devices in the unsaturated zone, and depth of well screens at $A$, site $1 ; B$, site $2 ; C$, site $3 ; D$, site 4 ; $E$, site $5 ; F$, site $6 ; G$, site 7 ; and $H$, site 8 in the Central Platte Natural Resources District unsaturated-zone network.-Continued 


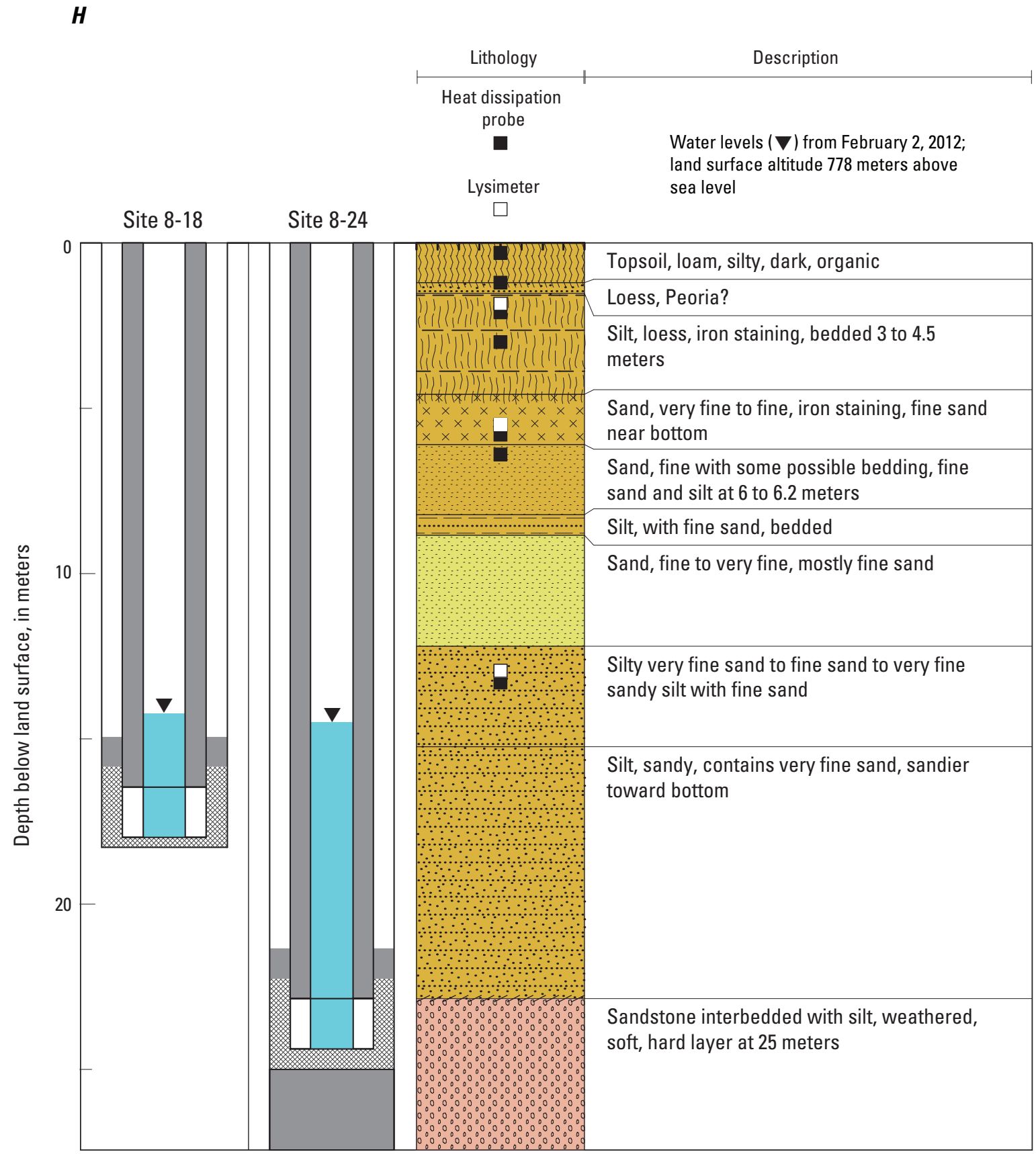

Figure 4. Lithology of unsaturated-zone sediment, depth of monitoring devices in the unsaturated zone, and depth of well screens at $A$, site $1 ; B$, site $2 ; C$, site $3 ; D$, site $4 ; E$, site $5 ; F$, site $6 ; G$, site 7 ; and $H$, site 8 in the Central Platte Natural Resources District unsaturated-zone network.-Continued 
sediment for analysis was cut into five nominally equal sections (about $0.15 \mathrm{~m}$ in length). Sections were capped on each end, taped, and labeled with location, date, depth interval of core, and purpose for core (as described next). Starting with the uppermost of the five sections and continuing to the bottom, the first section was used for analysis of ${ }^{3} \mathrm{H}$, the second section was used for analysis of chemistry (such as $\mathrm{NO}_{3}^{-}, \mathrm{Cl}^{-}$, and $\mathrm{Br}$ ), the third section was used for analysis of physical properties [bulk density $\left(\rho_{b}\right)$, porosity $(\varphi)$, volumetric water content $(\theta)$, and matric potential $\left.\left(\psi_{m}\right)\right]$, the fourth section was used for analysis of particle size, and the fifth section was archived. Sections used for ${ }^{3} \mathrm{H}$ analysis were taped heavily with duct tape to mask light penetration that could degrade ${ }^{3} \mathrm{H}$ present in the soil sample. Occasionally, sediment did not fill one or both sleeves. Incomplete volumes were cut into sections and prioritized for analysis or disposition in order: (1) physical properties, (2) chemical analysis, (3) particle size, (4) ${ }^{3} \mathrm{H}$, and (5) archival. Following coring and geologic logging of the borehole, inspection of the soil cuttings and the lithologic logs helped guide placement of the well screens and UZ instrumentation [heat-dissipation probes (HDPs) and suction lysimeters].

\section{Instrument Installation}

Unsaturated-zone instrumentation installed in the boreholes at all sites (fig. 4) consisted of a series of HDPs to measure $\psi_{m}$ (reported here in centimeters) and lysimeters to collect pore water from the UZ for chemical analyses. Before deployment, the HDPs (Model 229, Campbell Scientific, Inc., Logan, Utah) were calibrated at Daniel B. Stephens \& Associates, Inc., Soil Testing \& Research Laboratory at Albuquerque, New Mexico, following calibration methods outlined by Flint and others (2002).

Following methods outlined by McMahon and others (2003, 2006) and Gurdak and others (2007), the HDPs and pressure/suction lysimeters (Models 1920F1 and 1940, Soilmoisture Equipment Corp., Santa Barbara, California) were presoaked with deionized water. After soaking, the HDPs were wrapped in cheesecloth, and then embedded within a 200mesh silica flour slurry before installation. All HDPs (at depths greater than $0.3 \mathrm{~m}$ ) and suction lysimeters were attached to a 2.5-cm-diameter polyvinyl chloride (PVC) pipe. The HDPs at depths equal to or shallower than $0.3 \mathrm{~m}$ were placed in separate hand-dug holes. Boreholes were backfilled with 200-mesh silica flour (about 0.3-m thickness) surrounding the HDPs and the ceramic cup of the lysimeter. The 200-mesh silica flour was used to create and maintain a hydraulic connection between the instruments and the surrounding soil matrix. Granular bentonite was used to seal the annular space between instruments, and silica sand was used to separate the 200-mesh silica flour from the granular bentonite because some swelling of the bentonite was anticipated.
Wires leading from the HDPs were connected to a datalogger (Model CR1000, Campbell Scientific, Inc., Logan, Utah) located in an instrument shelter at the land surface. HDPs collected measurements at 4-hour intervals. The HDPs are capable of measuring $\psi_{m}$ from approximately -0.01 to -100 megapascals (MPa) with a sensitivity that is proportional to $\psi_{m}$ (Flint and others, 2002). Total water potential $\left(\psi_{T}\right)$ was calculated at the depth of each HDP as the sum of $\psi_{m}$ and gravimetric $\left(\psi_{g}\right)$ potentials, by assuming that thermal and osmotic potentials were negligible.

Two or three pressure/vacuum soil-water lysimeters were installed at various depths in the $\mathrm{UZ}$ at each site to collect pore water for analyses of concentrations of $\mathrm{NO}_{3}^{-}$and $\mathrm{Cl}^{-}$. The pressure/vacuum polyethylene access tubes leading from the lysimeters to land surface were capped with $15-\mathrm{cm}$ length neoprene tubing, used to apply suction so that soil water would collect in the lysimeter. Approximately 65 centibars suction was applied with a hand pump to the lysimeters for a period of 1 to 2 days before the pore water was collected.

All new wells were constructed from threaded $6.4-\mathrm{cm}$ diameter PVC with short, 1.5-m screens. The shallowest well at each site (except site 5) was instrumented with a pressure transducer (Model CS450, Campbell Scientific, Inc., Logan, Utah) to record changes in groundwater levels. At site 5, the three existing monitoring wells were approximately $8 \mathrm{~m}$ from the shelter. A new monitoring well located in the shelter had a depth of $16.8 \mathrm{~m}$, which was between the second shallowest and deepest of the existing monitoring wells, 13.7- and 19.5-m deep, respectively. The new well was instrumented for monitoring water level at site 5 , which was the only site where water-level data were not collected in the shallowest monitoring well.

Each site was installed with meteorological instruments to measure precipitation (Model TE525MM, 24.5-cm-diameter tipping-bucket rain gage, Campbell Scientific, Inc., Logan, Utah), wind speed and direction (Model 03001 RM, Campbell Scientific, Inc., Logan, Utah), solar radiation (Model LI200X, Campbell Scientific, Inc., Logan, Utah), air temperature and relative humidity (Model HMP45C, Campbell Scientific, Inc., Logan, Utah), and barometric pressure (Model CS105, Campbell Scientific, Inc., Logan, Utah). The HDP wires, the lysimeter tubing, and the meteorological instrumentation were housed in a weatherproof structure. With the exception of the lysimeters, all instruments were wired to a CR1000 datalogger, which was set up to accommodate data transmission by means of a cellular modem.

Cellular data transmissions enabled remote downloading of data, which were transmitted to the USGS Nebraska Water Science Center on a daily basis. All recorded time-series data from HDPs, meteorological instrumentation, and groundwater levels were stored in the USGS NWIS and served through the USGS NWISWeb portal at http://waterdata.usgs.gov/ nwis. 


\section{Site Identification}

Each study site has three different site identifiers (a site or project site number, a U.S. Geological Survey site identification number, and a local identifier), and all three were used in this report (table 1). The project site easily identifies each site (site 1 through site 8 ) and was the primary site identification used during the project. Sites 1-5 were numbered north to south and are located in the eastern part of the study area, just west of Grand Island, Nebr. Sites 6- 8 were labeled west to east and are located in the western part of the study area between the communities of Gothenburg and Lexington, Nebr. Two to four monitoring wells were associated with each site. To identify specific monitoring wells at a site, terminal numbers, which indicated the depth of the monitoring well (in meters), were added to form a second part of the site number, such as in "site 1-26." Hereinafter, the term "site" (such as site 1) refers to a specific study location and includes all monitoring wells and all equipment associated with that location; however, usage such as "site 1-26" refers to a specific monitoring well at that site.

The second identifier is the USGS site-identification number. USGS assigns a unique number to each sampling or measurement site when it is established. The identification numbers for wells are assigned according to the grid system of latitude and longitude, and consist of 15 digits (for example, 410102098374201). The first six digits denote the degrees, minutes, and seconds of latitude; the next seven digits denote degrees, minutes, and seconds of longitude; and the last two digits (assigned sequentially) identify the wells within a 1 -second grid. This 15-digit site-identification number, once assigned, has no longer any locational significance. For this study, the final two digits of the USGS site number do have significance: The " 01 " designates the shallowest monitoring well of a cluster, " 02 " designates the intermediate-depth monitoring well (hereinafter referred to as the intermediate well) of a cluster, and " 03 " designates the deepest monitoring well of a cluster. The two exceptions to the general usage were that designation " 02 " was used for the deepest monitoring well at site 8 where only two wells were present, and designation " 04 " was used for the deepest monitoring well at site 5, because four monitoring wells were present.

The third identifier is called a local identifier (such as $12 \mathrm{~N}$ 12W11DDDD1), and is based on the land subdivisions in the Public Land Survey System (National Atlas, 2013). The number preceding $\mathrm{N}$ (north of Base Line) indicates the township, the number preceding W (west of the 6th Principal Meridian) indicates the range, and the number preceding the terminal letters indicates the section in which the well is located. The terminal letters, combinations of A, B, C, and D, denote the quarter section, the quarter-quarter section, the quarter-quarterquarter section, and the quarter-quarter-quarter-quarter section, respectively. These designations are given in a counterclockwise direction beginning with " $\mathrm{A}$ " in the northeast corner of each subdivision. Each well also is assigned a terminal number, usually "1," designating the order of well inventory. Two or more wells that would otherwise share the same local identifier are distinguished by incrementing the terminal digit, in accordance with the order of their inventory.

\section{Laboratory and Data Analysis of Sediment Cores}

Soil cores from each site were lithologically described, sectioned, then either sent to laboratories for analysis or archived. Lithologic descriptions were based on general geologic characteristics of the sediment. Soil particle size, $\rho_{b}$, and $\theta$ (table 2, available at $h t t p: / / p u b s . u s g s . g o v /$ sir/2014/5008/ downloads/Tables.xlsx) were measured at the U.S. Department of Agriculture's Natural Resources Conservation Service (NRCS) Soil Survey Research and Laboratory (SSRL) in Lincoln, Nebr., using the NRCS classification and standard procedures (Soil Survey Staff, 1999). In this classification system, clay-sized particles are defined as particles smaller than 0.002 millimeter $(\mathrm{mm})$ in diameter, silt-sized particles are 0.002 to $0.05 \mathrm{~mm}$ in diameter, and sand-sized particles are 0.05 to $2.0 \mathrm{~mm}$ in diameter. Soil particles larger than $2.0 \mathrm{~mm}$ are considered rock fragments. Bulk density $\left[\rho_{b}\right.$, in grams per cubic centimeter $\left(\mathrm{g} \mathrm{cm}^{-3}\right)$ ] was determined by using equation 1 :

$$
\rho_{b}=M_{d} V_{s}^{-1}
$$

where

$M_{d} \quad$ is the dry mass of the sample, oven-dried at $105{ }^{\circ} \mathrm{C}$, and

$V_{s} \quad$ is the initial volume of the sample.

Samples were soil-core sections (as described in the "Site Installation" section). Volumetric water content $[\theta$, in cubic centimeter per cubic centimeter $\left.\left(\mathrm{cm}^{3} / \mathrm{cm}^{3}\right)\right]$ was measured at 6 and 10 kilopascals $(\mathrm{kPa})$ (very moist), $33 \mathrm{kPa}$ (moderately moist), and 1,500 kPa (slightly dry) (Soil Survey Division Staff, 1993), and expressed as a ratio of initial water volume to total sample volume (table 2). Additional NRCS SSRL laboratory methods are described in the NRCS soil survey field and laboratory methods manual (Burt, 2009) and Natural Resources Conservation Service (2004b).

Selected sediment cores were collected and analyzed for inorganic anions $\left(\mathrm{NO}_{3}^{-}, \mathrm{Cl}^{-}\right.$, and $\left.\mathrm{Br}^{-}\right)$and ${ }^{3} \mathrm{H}$ to assess the movement of water in the $\mathrm{UZ}$ and to estimate recharge rates. For $\mathrm{NO}_{3}^{-}, \mathrm{Cl}^{-}$, and $\mathrm{Br}^{-}$analysis, subsamples extracted from the soil cores were analyzed at the USGS Colorado Water Science Center (2008 and 2009 soil samples; given in table 3, available at http://pubs.usgs.gov/sir/2014/5008/downloads/Tables. $x l s x$ ). In April 2012, soil sediment cores were collected for $\mathrm{NO}_{3}^{-}, \mathrm{Cl}^{-}, \mathrm{Br}$, and $\theta$, and analyzed at the San Francisco State University (SFSU) Department of Earth \& Climate Sciences, Hydrogeology and Water Resources Research laboratory (table 3). The anions were extracted from the sediment and analyzed using the methods described by Lindau and Spalding (1984) and Herbel and Spalding (1993), with slight modification following the methods described by McMahon and 
others (2003). Cores were oven-dried at $50{ }^{\circ} \mathrm{C}$ for 24 hours, and approximately 10 grams $(\mathrm{g})$ of the dried sediment was combined with 25 milliliters $(\mathrm{mL})$ of deionized distilled water. The sediment-and-water mixture was hand-stirred for 1 minute and then placed on an orbital shaker for 1 hour at 170 revolutions per minute. After shaking, the mixture was centrifuged for 10 minutes, and the liquid layer then was separated and filtered through a 0.45 -micron $(\mu \mathrm{m})$ filter. Anion concentrations in the filtered solution were quantified at each respective laboratory (USGS Colorado Water Science Center or SFSU) using ion chromatography (McMahon and others, 2003). Anion concentrations were reported on a dry-weight basis [micrograms per gram $(\mu \mathrm{g} / \mathrm{g})$ dry sediment] and converted to a volume basis [milligrams per liter ( $\mathrm{mg} / \mathrm{L}$ ) water)] using the gravimetric water content of the sediment when $\mathrm{Cl}^{-}$and $\mathrm{Br}^{-}$ concentrations in soil water were used to estimate water flux in the unsaturated zone.

Specific anions, such as $\mathrm{Cl}^{-}$, are useful as a tracer of water movement in the UZ because they are chemically conservative, nonvolatile (no vapor transport), and generally are not taken up by plants (McMahon and others, 2003). Chloride profiles were used to estimate water fluxes in the UZ using equation 2 :

$$
q=\frac{q_{C l^{-}}}{c_{C l^{-}}}
$$

where

$$
\begin{aligned}
& q \quad \text { is the water flux, in millimeter per year; } \\
& q_{C l-} \quad \text { is chloride flux at the land surface, in grams } \\
& \text { per square meter per year; and } \\
& c_{C l-} \text { is the chloride concentration in soil pore water } \\
& \text { in grams per cubic meter. }
\end{aligned}
$$

The value of $q_{C l}$ is approximated by the product of the annual precipitation rate and chloride concentration in wet plus dry deposition (McMahon and others, 2003). The primary assumptions with the use of equation 2 to estimate water fluxes are that (1) precipitation is the only source of $\mathrm{Cl}^{-}$, (2) water and $\mathrm{Cl}^{-}$movement are represented by onedimensional downward piston-type flow, and (3) the $\mathrm{Cl}^{-}$flux at the land surface was constant during the previous several decades (Allison and Hughes, 1978; Johnston, 1987; Scanlon, 1991). Because irrigation water and potassium chloride $(\mathrm{KCl})$ applications may have been additional sources of $\mathrm{Cl}^{-}$at the irrigated and dryland sites, equation 2 was applied to the rangeland sites only (sites 1, 4, and 8). As illustrated in the "Water Movement Through the Unsaturated Zone" section, the $\psi_{T}$ time series and ${ }^{3} \mathrm{H}$ profiles at sites 1,4 , and 8 are consistent with piston-type flow; however, the authors are not able to evaluate the validity of the third assumption with the available data.

A subset of the soil samples were sent to the USGS Reston Stable Isotope Laboratory at Reston, Virginia, for analysis of nitrate isotopes in $\mathrm{NO}_{3}{ }^{-}$. Methods for analytical procedures used by the USGS Reston Stable Isotope Laboratory (U.S. Geological Survey, 2013a). Water for ${ }^{3} \mathrm{H}$ analysis was extracted from sediment cores by vacuum distillation at $90{ }^{\circ} \mathrm{C}$ and analyzed by liquid scintillation with electrolyte enrichment at the USGS Tritium Laboratory at Menlo Park, California (Calif.) (Thatcher and others, 1977). The 1-sigma precision for the ${ }^{3} \mathrm{H}$ analysis ranged from plus or minus $( \pm) 0.5$ to \pm 4.0 tritium units (TU). Results from moist or wet cores had a better 1-sigma precision than those from dry cores because of the presence of additional water for analysis (Robert Michel, U.S. Geological Survey, written commun., 2011).

Concentrations of major ions and nutrients such as $\mathrm{NO}_{3}^{-}$ in the UZ and the groundwater underlying specific land-use areas can be indicative of recharge rates. Chloride and radiological markers such as ${ }^{3} \mathrm{H}$ can be used as tracers to determine recharge rates through the $\mathrm{UZ}$ because $\mathrm{Cl}^{-}$is generally conservative in the UZ (Allison and Hughes, 1978) and ${ }^{3} \mathrm{H}$ exists as part of the water molecule. In addition, ${ }^{3} \mathrm{H}$, with a half-life of 12.32 years (yr) (Michel, 2005) was the first environmental tracer used for groundwater-age dating (Kaufman and Libby, 1954; Nir, 1964).

Tritium is one of the most commonly used radioisotopes to age modern groundwater recharge because ${ }^{3} \mathrm{H}$ is incorporated into the water molecule, which makes it the only radioisotope that actually dates groundwater. Tritium in the UZ originates from meteoric precipitation (Clark and Fritz, 1997) and is produced naturally by cosmic radiation. Much greater production of ${ }^{3} \mathrm{H}$ in the atmosphere was associated with thermonuclear testing between 1951 and 1980, and atmospheric concentrations of ${ }^{3} \mathrm{H}$ in North America peaked in 1963 (Clark and Fritz, 1997; McMahon and others, 2006). Hereinafter, all ${ }^{3} \mathrm{H}$ that entered the UZ before 1953 is referred to as "prebomb" ${ }^{3} \mathrm{H}$, and all ${ }^{3} \mathrm{H}$ that entered the UZ after 1953 is referred to as "post-bomb" ${ }^{3} \mathrm{H}$. Before the onset of nuclear weapons testing, the ${ }^{3} \mathrm{H}$ concentration in meteoric precipitation in Nebraska was around 5 TU (Robert Michel, U.S. Geological Survey, written commun., 2004) and was estimated at about 8 TU for the central United States (Thatcher, 1962). Given natural decay processes, a 5 - or 8-TU pre-bomb ${ }^{3} \mathrm{H}$ concentration today (2014) would be approximately $0.3 \mathrm{TU}$. Tritium concentrations are often plotted as a function of depth in UZ profiles. The "pre-bomb/post-bomb ${ }^{3} \mathrm{H}$ interface" is interpreted as the depth in the $\mathrm{UZ}$ where ${ }^{3} \mathrm{H}$ concentrations decrease to less than or equal to the $0.3 \mathrm{TU}$ pre-bomb levels. This depth approximates the maximum depth at which water entering the subsurface since 1953 (the beginning of the post-bomb age) has infiltrated the UZ.

Using the $1963{ }^{3} \mathrm{H}$ peak, McMahon and others (2006) determined a flux using equation 3 to determine recharge from a ${ }^{3} \mathrm{H}$ peak in a soil profile:

$$
q=\frac{\theta_{v w} z_{q}}{t}
$$

where

$$
\begin{array}{cl}
q & \text { is the water flux, in millimeters per year; } \\
\theta_{v w} & \text { is the depth-weighted mean volumetric water } \\
& \text { content, in cubic centimeter per cubic } \\
\text { centimeter; }
\end{array}
$$


$z_{q} \quad$ is the depth (m) of either the pre-bomb/postbomb ${ }^{3} \mathrm{H}$ interface or the ${ }^{3} \mathrm{H}$ center of mass; and

is time (years) elapsed since the atmospheric thermonuclear device testing that peaked in 1963.

For this study, if the ${ }^{3} \mathrm{H}$ peak was present, $t$ was calculated as the time elapsed from 1963 to the time of sampling. If the ${ }^{3} \mathrm{H}$ peak was absent, the pre-bomb/post-bomb interface was used, and $t$ was calculated as the time elapsed from 1953 to the time of sampling. The peak displacement method assumes that movement in the UZ is dominated by piston flow (Izbicki and others, 2002), where flow lines in the UZ are uniform and mixing is minimal.

Water flux also was calculated using a ${ }^{3} \mathrm{H}$ mass-balance method using equation 4 as described by Allison and Hughes (1978) and McMahon and others (2003):

$$
q=\left(\mathrm{W}_{T} / t\right)\left(T / T_{T}\right)
$$

where

$$
\begin{aligned}
& W_{T} \text { is the total water (precipitation plus irrigation, } \\
& t \quad \text { is the elapsed time (years since 1953); } \\
& T \quad \text { is the measured amount of }{ }^{3} \mathrm{H} \text { in the } \mathrm{UZ} \text { above } \\
& \text { the pre-bomb/post-bomb interface, in } \\
& \text { tritium unit meters; and } \\
& T_{T} \quad \text { is the total amount of }{ }^{3} \mathrm{H} \text { that could have been } \\
& \text { added to the profile since 1953, in tritium } \\
& \text { unit meters. }
\end{aligned}
$$

The value of $W_{T}$ was estimated using historical precipitation records from the Grand Island Central Nebraska Regional Airport (National Climate Data Center station identification 253395) for sites 2 and 3 and from Gothenburg, Nebr., (National Climate Data Center station identification 253365) for site 8 (National Ocean and Atmospheric Administration, 2013). Annual estimates of the irrigation water applied were determined through CROPSIM simulations (Peterson, 2007) and were the same estimates used in the COHYST groundwater model from the onset of irrigation through 2005 (Duane Woodward, Central Platte Natural Resources District, oral commun., 2012). Estimates of the irrigation water applied from 2006 through the sampling date were estimated using weighted averages of precipitation and irrigation application estimates from 1950 to 2005 . The value $T_{T}$ was determined using historical records from Lincoln, Nebr., (1962-86; Robert Michel, written commun., 2004). For periods of missing data, the ${ }^{3} \mathrm{H}$ record in precipitation was reconstructed using correlation coefficients from periods of overlap with the record from Ottawa, Ontario, Canada (Michel, 2005).

The value $T$ is obtained by integrating the ${ }^{3} \mathrm{H}$ profile from the land surface to the pre-bomb/post-bomb interface using equation 5 :

$$
T=\int_{0}^{z} T_{z} \theta_{z} d z
$$

where

$T_{z}$ and $\theta_{z} \quad$ are the ${ }^{3} \mathrm{H}$ concentration, in tritium units; and

$\theta_{z} \quad$ is cubic centimeter per cubic centimeter at depth $z$, in meters.

The total amount of ${ }^{3} \mathrm{H}$ that could have been added to the subsurface profile since 1953 was calculated using equation 6 , which corrects for decay:

$$
T_{T}=\sum_{n=1}^{t} w_{n} T_{n} \exp (n \lambda)
$$

where

$$
\begin{aligned}
n & \text { is years before time of sampling; } \\
t & \text { is elapsed time, in years since 1953; } \\
w_{n} & \text { is a weighting function which takes into } \\
& \text { account year-to-year variations in recharge; } \\
T_{n} & \text { is the }{ }^{3} \mathrm{H} \text { content of precipitation in year } n ; \\
\exp & \text { is the exponential function; and } \\
\lambda & \text { is the rate constant for }{ }^{3} \mathrm{H} \text { decay } \\
& \left(0.0563 \text { year }^{-1}\right) .
\end{aligned}
$$

The time-varying ${ }^{3} \mathrm{H}$ concentration in precipitation, $T_{n}$, was estimated from ${ }^{3} \mathrm{H}$ concentrations in precipitation used for $T_{T}$. The weighting function $\left(w_{n}\right)$ used in equation 6 was calculated using data from the same sources used for $W_{T}$ in equation 4 , as the following:

$w_{n} \quad=$ (precipitation plus applied irrigation water applied in year $n) /($ mean annual irrigation and precipitation from 1953 to the date of sampling).

Assumptions made before applying the mass-balance method included (1) applied irrigation water does not contain post-bomb ${ }^{3} \mathrm{H}$, and (2) post-bomb ${ }^{3} \mathrm{H}$ has not reached the water table. Allison and others (1994) reported that the mass-balance method is independent of the ${ }^{3} \mathrm{H}$ profile distribution and therefore is independent of preferential flow effects.

Two methods were used to analyze the penetration depth of the $\mathrm{Br}^{-}$in meters $\left(Z_{T}\right)$. To analyze the $\mathrm{Br}^{-}$profiles, the authors used: (1) peak tracer concentration (observed in data) and (2) the center of tracer mass (eq. 7) (Walker, 1998; Healy, 2010):

$$
\begin{gathered}
Z_{T}=\int_{0}^{\infty} z C(z) \theta(z) d z / M \\
M=\int_{0}^{\infty} C(z) \theta(z) d z
\end{gathered}
$$

where

$C(z) \quad$ is the $\mathrm{Br}^{-}$concentration in pore water, in milligrams per liter;

$M \quad$ is the total mass of the $\mathrm{Br}^{-}$in the subsurface, in grams; and

$\theta \quad$ is cubic centimeter per cubic centimeter at depth $z$, in meters. 


\section{Data and Sample Collection}

Total water potential in the UZ was measured using matric potential $\left(\psi_{m}\right)$. All groundwater sites were sampled for a suite of constituents ranging from radioisotopes to major ions to environmental tracers. This section describes the $\psi_{m}$ and groundwater measurement methods as well as methods used to collect the groundwater samples during this study.

\section{Unsaturated Zone}

To determine site-specific recharge rates using a tracer, on June 23 and 24, 2009 (sites 2 and 1, respectively), and June 23 and 24, 2011 (sites 3-5 and 6-8, respectively), potassiumbromide $(\mathrm{KBr})$ was applied to the surface for infiltration tests. Topsoil was prepared by marking an area of approximately $3 \times 3-\mathrm{m}$ from the center of each site's instrument shelter, and then removing vegetation to bare earth within the $3 \times 3-\mathrm{m}$ area. Total barren area around each shelter was about 8 square meters $\left(\mathrm{m}^{2}\right)$ (shelter pad was about $\left.1 \mathrm{~m}^{2}\right)$. The $\mathrm{KBr}$ salt $(400 \mathrm{~g}$ ) was mixed with 4 liters (L) of deionized water for a ratio of about 10:1. A total of about $8 \mathrm{~L}$ of mixture was applied by pressure spray to the barren area for a coverage of about $100 \mathrm{~g} / \mathrm{m}^{2}$. Water samples were collected from the suction lysimeters during subsequent visits and analyzed for fluoride $\left(\mathrm{F}^{-}\right)$, nitrite $\left(\mathrm{NO}_{2}^{-}\right), \mathrm{NO}_{3}^{-}, \mathrm{Cl}^{-}$, sulfate $\left(\mathrm{SO}_{4}^{2-}\right)$, phosphate $\left(\mathrm{PO}_{4}^{3-}\right)$, and $\mathrm{Br}$.

During April 3-5, 2012, continuous soil cores were collected at all eight sites to determine the infiltration depths of the $\mathrm{KBr}$ salt applied during 2009 and 2011. Continuous soil cores were collected using a single nominal $0.05 \times 1.2-\mathrm{m}$ stainless steel tube containing a PVC liner. The continuous soil cores were collected to a nominal depth of $4.9 \mathrm{~m}$ at sites 1-6. Shallow groundwater prevented coring past $2.4 \mathrm{~m}$ at site 7 , and soil samples from depths of 3.7 to $4.9 \mathrm{~m}$ were not collected in a PVC liner at site 8.

The 5-cm PVC liners were used to contain the sediment sample during the coring and extract the soil sample to the surface for description. Following description of each soil core, the 1.2-m PVC liner was sliced into four segments of about $0.3-\mathrm{m}$ length, capped, taped, and then labeled with location, depth, and date. The soil cores were sent to the SFSU for analysis of $\mathrm{Br}$.

\section{Matric Potential}

Matric potentials were measured in the field using HDPs (Model 229, Campbell Scientific, Inc., Logan, Utah). The HDP is a cylindrical porous ceramic body with a thermocouple wire pair and a heater wire embedded in a hypodermic needle, which is embedded inside at the center of the unit. Because of differences in heat-transfer properties that exist between individual sensors, all HDPs were calibrated as described in the "Instrument Installation" section. The sensor operates by passing a current through the heater wire and measuring the thermocouple temperature rise with time. The rate of heat dissipation is dependent on the thermal conductivity, which changes with changes in $\theta$. After installation, the HDPs were allowed to equilibrate to the same $\psi_{m}$ as the surrounding soil. As mentioned previously in the "Instrument Installation" section, $\psi_{m}$ values were used to calculate $\psi_{T}$ and referenced to the water table as the sum of $\psi_{m}$ and $\psi_{g}$, which assumes that the thermal and osmotic potentials are negligible (McMahon and others, 2006; Gurdak and others, 2007).

\section{Groundwater}

Groundwater levels were measured manually in all monitoring wells during routine sampling events, and monitored continually in the shallowest well at each site using a submersible pressure transducer set to record at hourly intervals. Manual groundwater-level measurements were collected according to USGS groundwater technical procedures (Cunningham and Schalk, 2011).

Groundwater samples were collected using standard procedures described in the USGS National Water Quality Field Manual (NWQFM) (U.S. Geological Survey, variously dated). Samples collected from the 23 monitoring wells in either 2009 or 2010 are listed in appendix table $1-1$, available at $h t t p: / /$ pubs.usgs.gov/sir/2014/5008/downloads/Tables.xlsx. Water samples were analyzed on-site using a flow-through chamber and a multiprobe water-quality meter for physical properties $(\mathrm{pH}$, water temperature, specific conductance, and alkalinity). Water samples were collected when properties stabilized within a set parameters, chilled and preserved as required by NWQFM procedures, then sent to the USGS National Water Quality Laboratory (NWQL) at Denver, Colorado, for analysis of major ions [including calcium $\left(\mathrm{Ca}^{2+}\right)$, magnesium $\left(\mathrm{Mg}^{2+}\right)$, sodium $\left(\mathrm{Na}^{+}\right)$, potassium $\left(\mathrm{K}^{+}\right), \mathrm{SO}_{4}{ }^{2-}$, and $\mathrm{Cl}^{-}$], and nutrients [including nitrite plus $\mathrm{NO}_{3}^{-}$, nitrogen as $\mathrm{N}\left(\mathrm{N}^{3-}\right)$, and orthophosphate as $\left.\mathrm{PO}_{4}\left(\mathrm{PO}_{4}^{3-}\right)\right]$. Methods for analytical procedures used by the NWQL are described by the U.S. Geological Survey (2013b).

Concurrent with collection of groundwater samples for analysis of major ions and nutrients, water samples also were collected for analysis of groundwater residence time using atmospheric environmental tracers: dissolved gases, chlorofluorocarbons (CFCs) (CFC-12, dichlorodifluoromethane, $\mathrm{CF}_{2} \mathrm{Cl}_{2} ; \mathrm{CFC}-11$, trichlorofluoromethane, $\mathrm{CFCl}_{3}$; and $\mathrm{CFC}-113$, trichlorotrifluoroethane, $\left.\mathrm{C}_{2} \mathrm{~F}_{3} \mathrm{Cl}_{3}\right),{ }^{3} \mathrm{H}$, tritium/ helium $\left({ }^{3} \mathrm{H} /{ }^{3} \mathrm{He}\right)$, and sulfur hexafluoride $\left(\mathrm{SF}_{6}\right)$. Water samples analyzed for dissolved gases, $\mathrm{CFCs}$, and $\mathrm{SF}_{6}$ were sent to the USGS Reston Chlorofluorocarbon Laboratory (RCL) at Reston, Virginia. Methods for analytical procedures used by the USGS RCL are described in Busenberg and Plummer (1992, 2000), and Busenberg and others (1998) and references therein. Water samples analyzed for ${ }^{3} \mathrm{H}$ analysis (Thatcher and others, 1977) were sent to the USGS Isotope Tracers Project laboratory at Menlo Park, Calif. Water samples analyzed for ${ }^{3} \mathrm{H} /{ }^{3} \mathrm{He}$ were sent to the Lamont-Doherty Earth Observatory (LDEO) of Columbia University at Palisades, New York. Methods for analytical procedures used by LDEO are described by Ludin and others (1998). 
Contamination, mixing, degradation of tracer concentrations, or the absence of environmental tracers in groundwater samples precluded analyses of all tracers from all monitoring wells. Thus, no single tracer could be used to interpret the apparent groundwater age of all monitoring wells. Consequently, different lumped-sum models using different tracers were used to model the apparent groundwater age or residence time (appendix table 1-2, available at http://pubs.usgs.gov/ sir/2014/5008/downloads/Tables.xlsx). Multiple interpretations of the environmental tracers are possible using different models. For this study, methods for analysis of the groundwaterage dating samples follow methods described by Jurgens and others (2012).

\section{Quality Assurance and Quality Control}

Quality-assurance (QA) procedures for the study included collecting additional samples to evaluate the effectiveness of the quality-control (QC) measures. The QC measures for the study included collection of field blanks and equipment blanks, and field replicates (appendix table 1-3, available at http://pubs.usgs.gov/sir/2014/5008/downloads/Tables.xlsx). The QC samples were used to evaluate the possibility of sample contamination and bias (the accuracy) and the overall replicability (precision) of results from the groundwater sampling and analysis methods for major ions and nutrients.

Equipment-blank and field-blank results indicated that some constituents were observed in water-quality sample analysis, although in small amounts (appendix table 1-3). The largest concentration of a constituent detected in the equipment blank was $\mathrm{Ca}^{2+}$ (about $0.5 \mathrm{mg} / \mathrm{L}$ ); however, the concentration in the equipment blank is about 0.4 percent of the smallest concentration detected in the environmental samples collected in 2010 (115 mg/L at site 8; appendix table 1-1). In addition, manganese $\left(\mathrm{Mn}^{2+}\right)$ was the only other constituent detected in any appreciable concentration in the equipment blank $(0.66 \mu \mathrm{g} / \mathrm{L})$ and the field blank samples $(0.39 \mu \mathrm{g} / \mathrm{L}$ in 2010). Detections of $\mathrm{Mn}^{2+}$ in the equipment blank sample for May 2009 coincided with detections in the environmental $(0.51 \mu \mathrm{g} / \mathrm{L})$ and replicate $(0.33 \mu \mathrm{g} / \mathrm{L})$ samples (appendix table 1-3). At such small concentrations it is not possible to determine if the measured $\mathrm{Mn}^{2+}$ concentrations are representative of the environment or if they resulted from sampling contamination. All other $\mathrm{Mn}^{2+}$ concentrations measured in water samples during May 2009 were substantially larger than the field-blank sample.

Differences between the environmental and replicate samples were evaluated using a relative percent difference (RPD) method (that is, absolute value of the difference divided by the average value of the two samples multiplied by 100) (appendix table 1-3). The RPDs during the study generally were less than 5 percent but ranged from 0 to 43 percent. Four RPDs exceeded 10 percent-two samples collected May 19, 2009 (RPD for $\mathrm{Mn}^{2+}$ was 43 percent; RPD for $\mathrm{Na}^{+}$ was 18 percent), and two samples collected September 1, 2010 [RPD for orthophosphate as $\mathrm{PO}_{4}$ was 15 percent and orthophosphate as $\mathrm{P}$ was 16 percent] (appendix table 1-3). The large RPDs resulted from differences between very small concentrations (less than $0.1 \mathrm{mg} / \mathrm{L}$ for orthophosphates and less than $0.2 \mu \mathrm{g} / \mathrm{L}$ for $\mathrm{Mn}^{2+}$ ). Small differences between very low-level concentrations can indicate large variability (low precision at those concentration levels). The reason for the 15- and 16-percent RPDs for the ortho- $\mathrm{PO}_{4}$ and ortho- $\mathrm{PO}_{4}$ as $\mathrm{P}$, respectively, could not be determined; however, these larger RPDs only existed in the sample collected in 2010 (appendix table 1-3) and concentrations of ortho- $\mathrm{PO}_{4}$ and ortho- $\mathrm{PO}_{4}$ as $\mathrm{P}$ in the environmental and replicate samples both were less than $1 \mathrm{mg} / \mathrm{L}$. Contamination did not appear to be a factor in the RPD of 18 for $\mathrm{Na}^{+}$because $\mathrm{Na}^{+}$was not detected in the field blank.

Quality-control measures also were used during extraction of soil water. During the ion chromatography, as described in the "Laboratory Analysis of Sediment Cores" section, method blanks were inserted after every 10th environmental sample by subjecting distilled deionized water to the extraction process to verify that the process did not contaminate samples. Analyses of method blanks indicated the extraction procedure was not a substantial source of dissolved inorganic anions (appendix table 1-3). A replicate sample also was collected after every 10th environmental sample to assess the combined effects of field and laboratory procedures on measurement variability.

\section{Water Movement through the Unsaturated Zone}

A number of lines of evidence were used to evaluate water movement through the UZ and estimate recharge rates at the study sites. Total water potentials $\left(\psi_{T}\right)$ were used to evaluate the direction of water movement and characterize wetting fronts in the UZ (figs. 5-10). Tritium, $\mathrm{Cl}^{-}, \mathrm{NO}_{3}^{-}$, and $\mathrm{Br}^{-}$concentration profiles in $\mathrm{UZ}$ pore water were used to estimate water fluxes in the UZ and recharge rates (figs. 11-18, shown in "Total Water Potentials"). These methods implicitly assume that water flow in the UZ is one-dimensional. Groundwater ages also were used to estimate water movement through the UZ and recharge rates (table 4). The selected UZ and groundwater-based methods resulted in water velocities and estimates of recharge rates that represent a range of spatial and temporal scales (Scanlon and others, 2002). Water movement and recharge estimates from the UZ-based methods generally apply to small spatial scales and days to decadal time scales. Water movement and recharge estimates from the groundwater-based approach generally apply to large spatial scales and years to multidecadal time scales. The results of these methods are presented in the following sections. 
$\boldsymbol{A}$

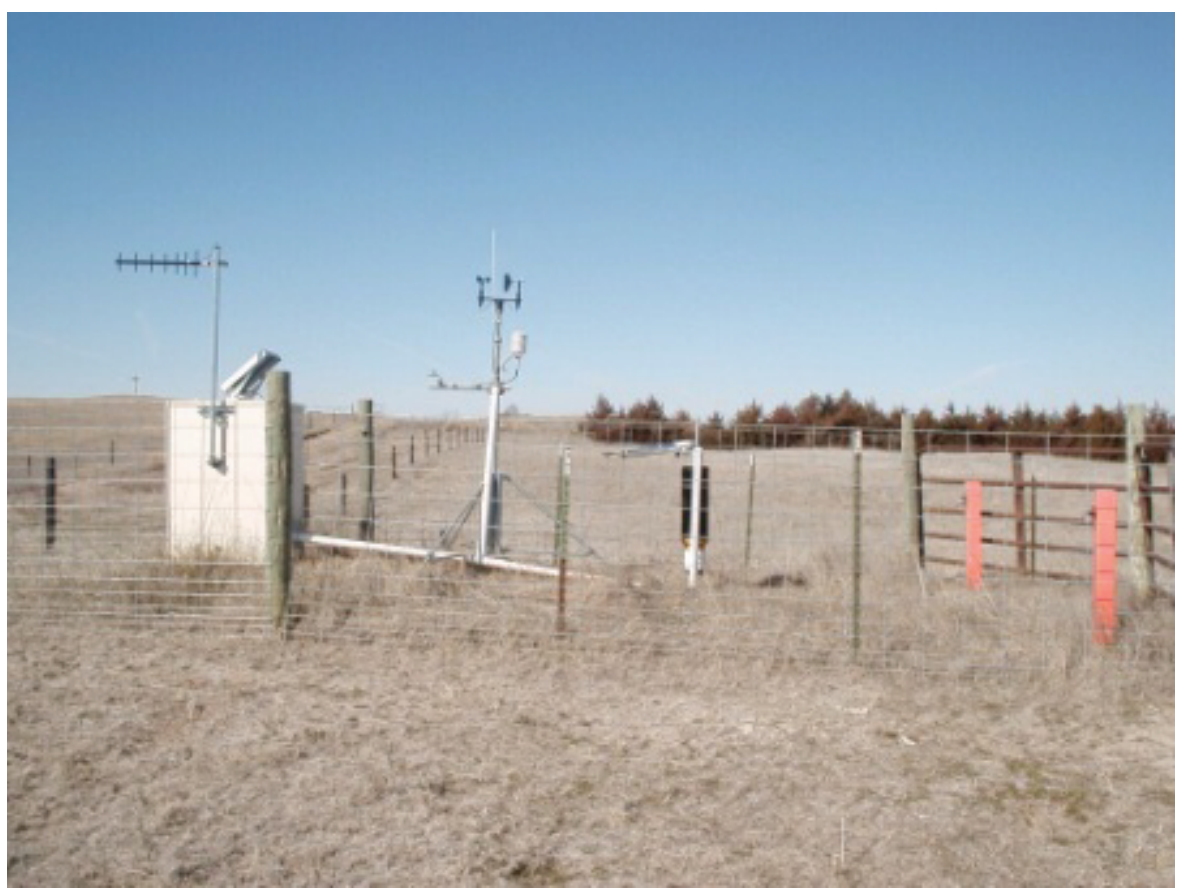

Photograph by Greg Steele, U.S. Geological Survey

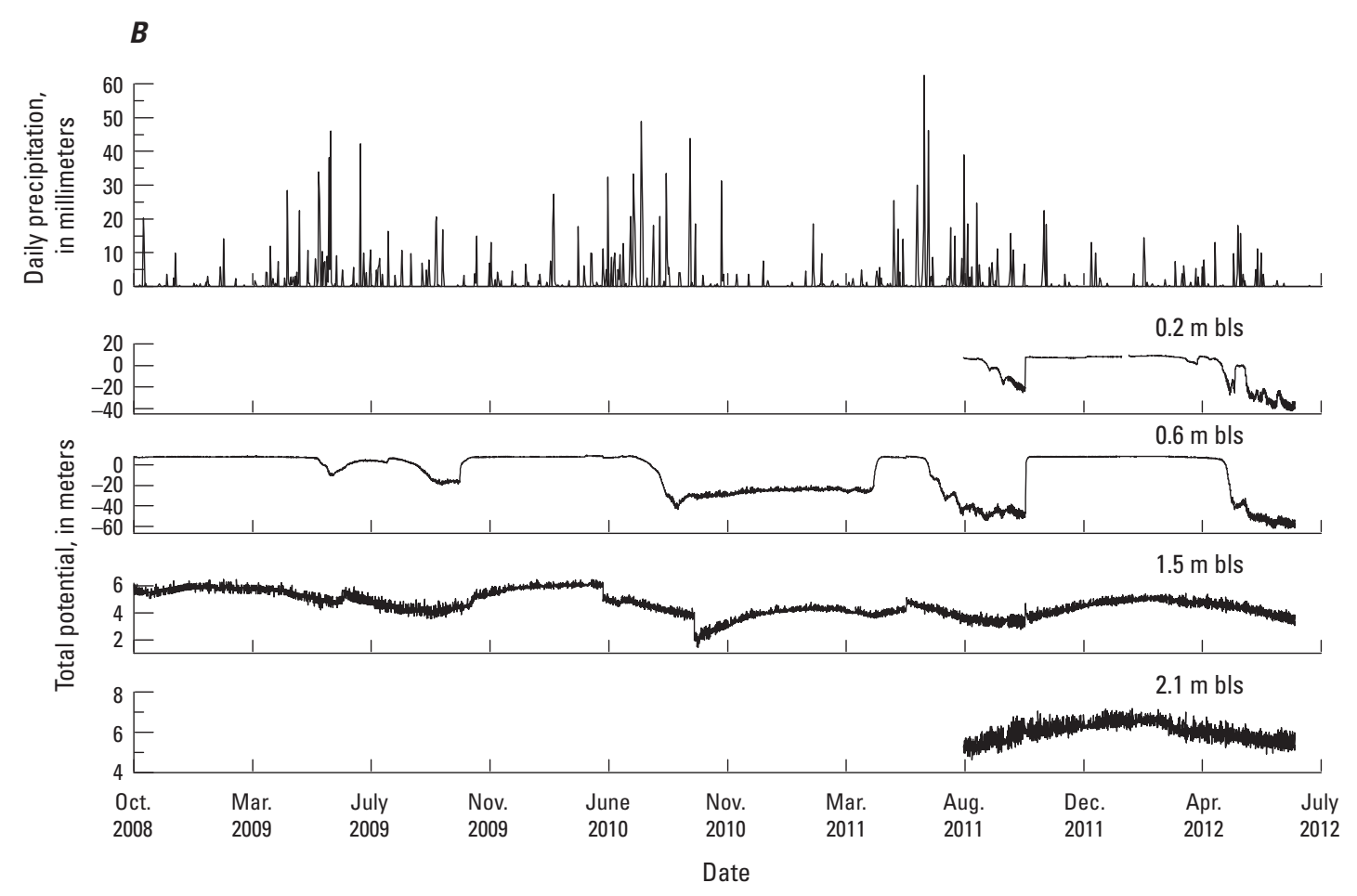

Figure 5. $A$, photograph of the unsaturated-zone study site 1 and the surrounding rangeland; and $B$, time series of daily precipitation in millimeters and total (matric plus gravimetric) potential in meters for selected depths below land surface (bls) at site 1 (National Oceanic and Atmospheric Administration, 2013). 
A

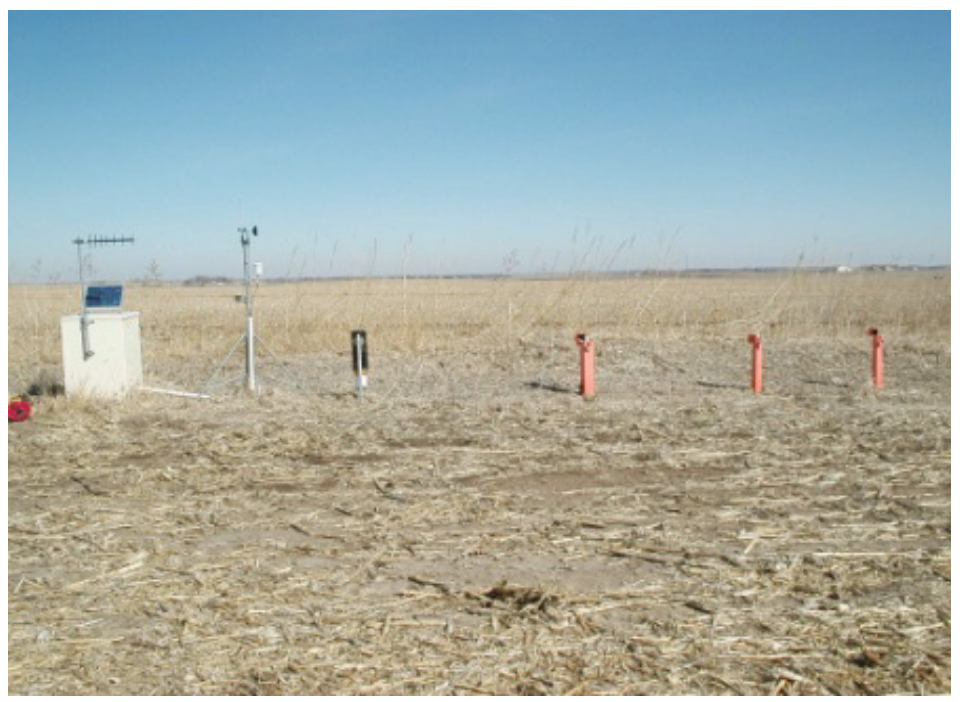

B

Photograph by Greg Steele, U.S. Geological Survey
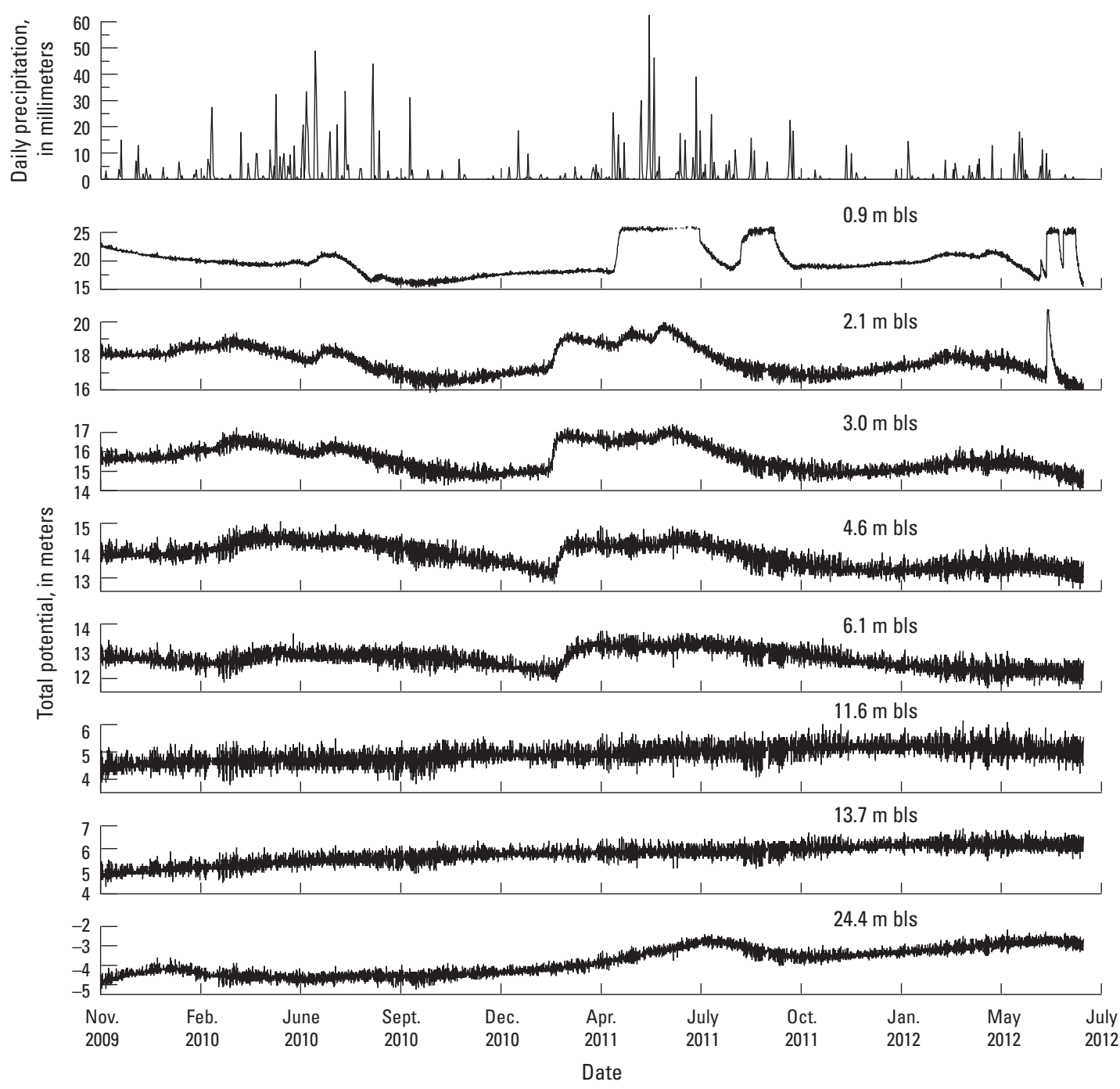

Figure 6. $A$, photograph of the unsaturated-zone study site 2 and the surrounding irrigated corn field; and $B$, time series of daily precipitation in millimeters and total (matric plus gravimetric) potential in meters for selected depths below land surface (bls) at site 2 (National Oceanic and Atmospheric Administration, 2013). 
$\boldsymbol{A}$

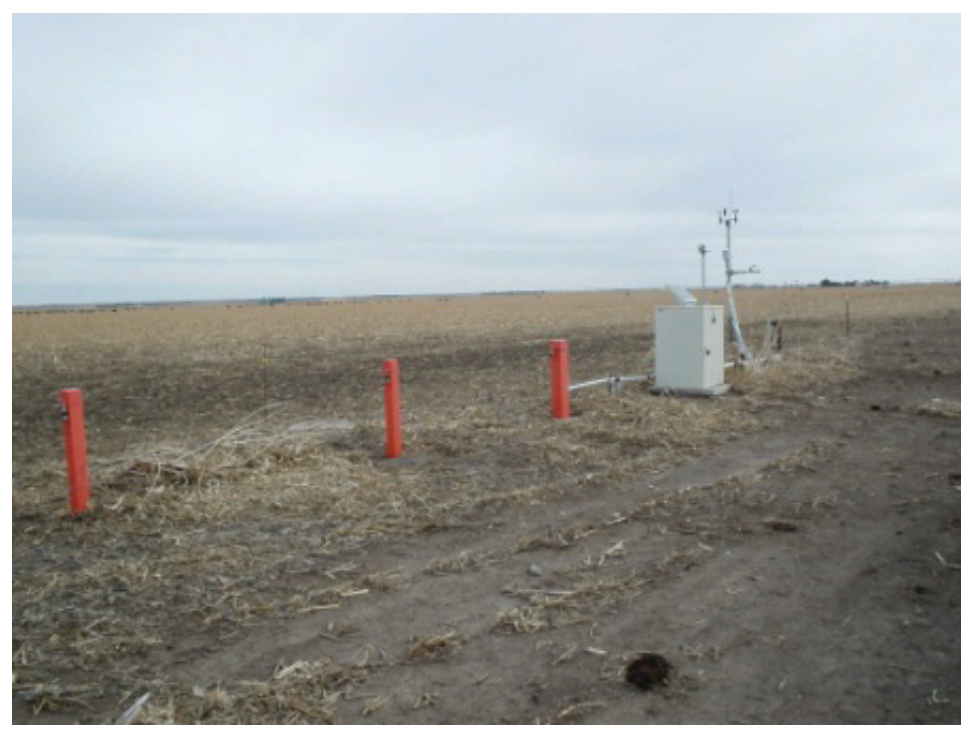

Photograph by Greg Steele, U.S. Geological Survey
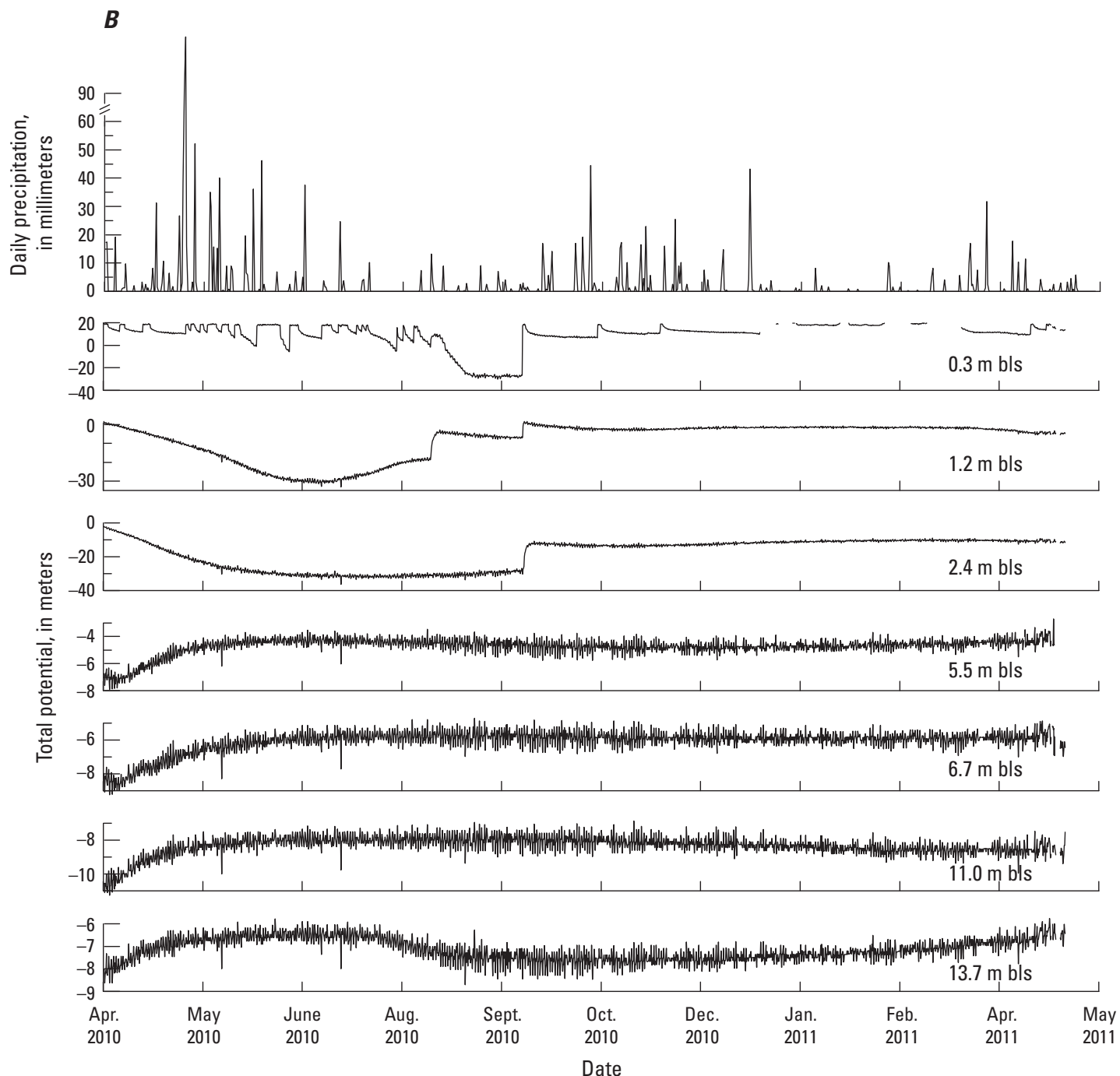

Figure 7. $A$, photograph of the unsaturated-zone study site 6 and the surrounding irrigated corn field; and $B$, time series of daily precipitation in millimeters and total (matric plus gravimetric) potential in meters for selected depths below land surface (bls) at site 6 (National Oceanic and Atmospheric Administration, 2013). 
A

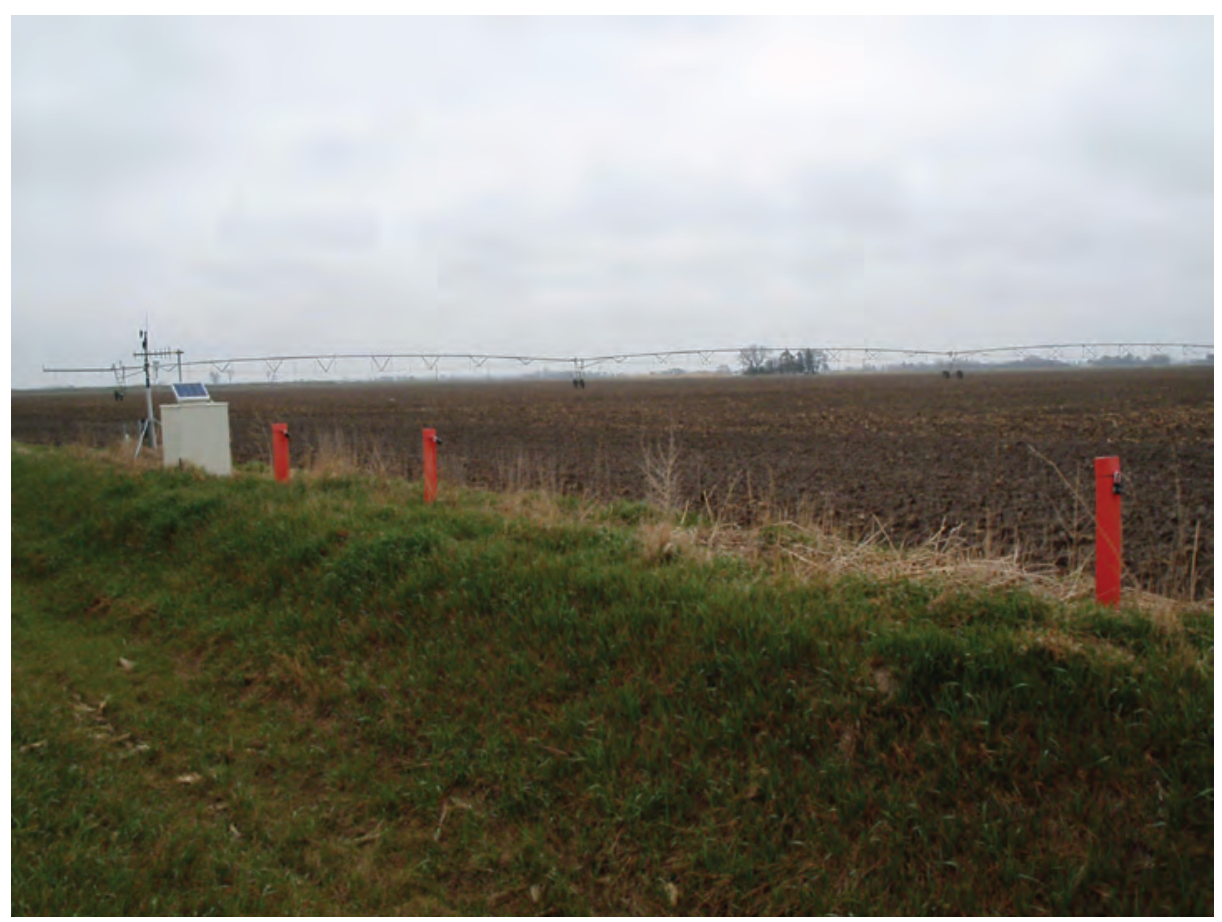

Photograph by Greg Steele, U.S. Geological Survey

B

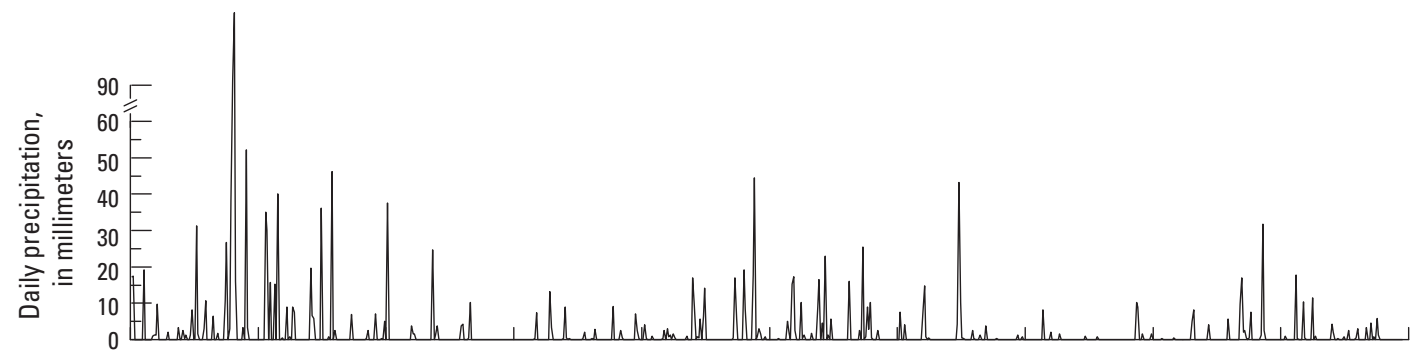

$0.2 \mathrm{~m}$ bls

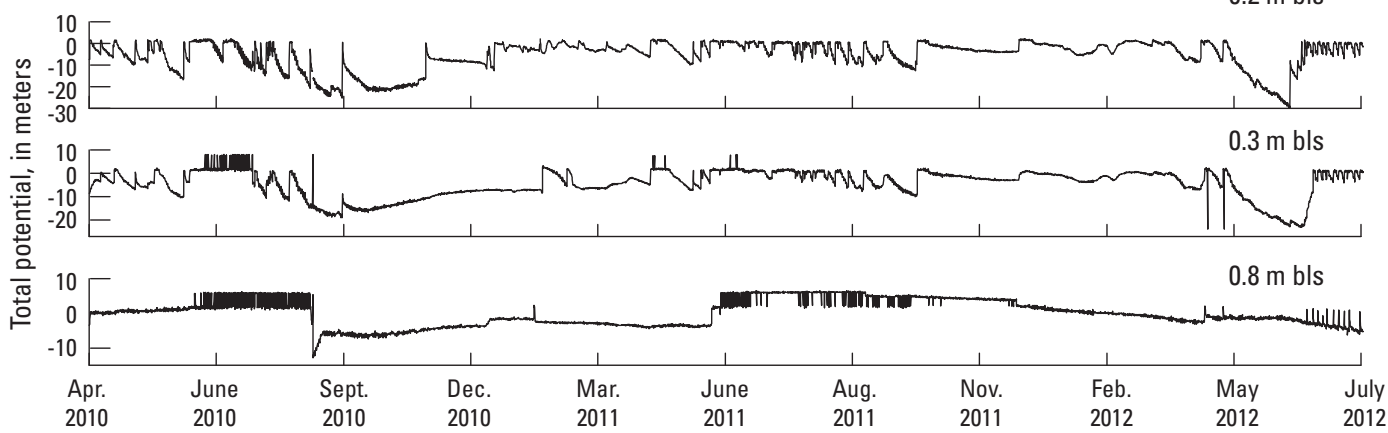

Date

Figure 8. $A$, photograph of the unsaturated-zone study site 7 and the surrounding irrigated corn field; and $B$, time series of daily precipitation in millimeters and total (matric plus gravimetric) potential in meters for selected depths below land surface (bls) at site 7 (National Oceanic and Atmospheric Administration, 2013). 
A

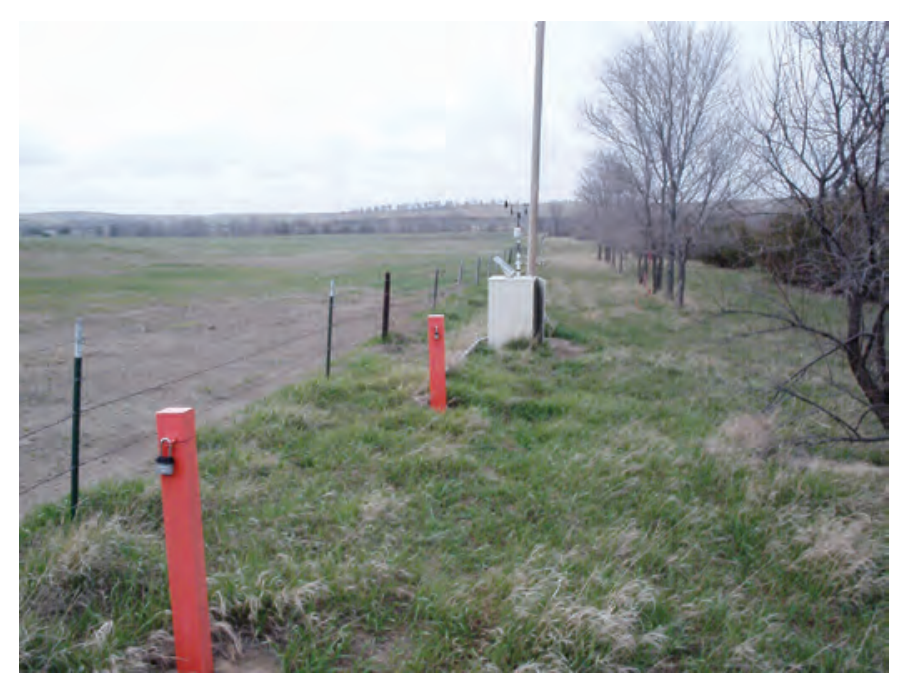

Photograph by Greg Steele, U.S. Geological Survey

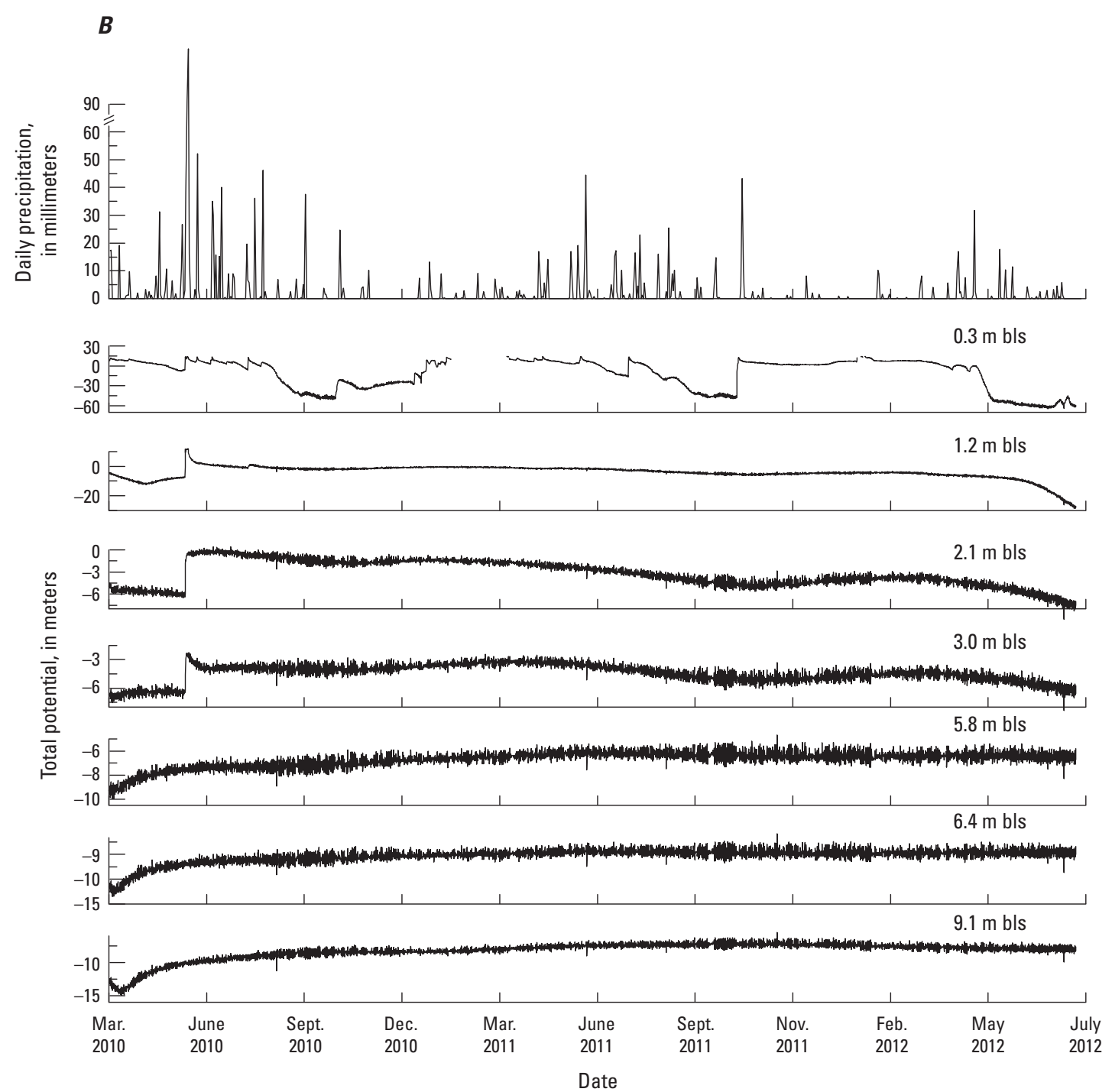

Figure 9. A, photograph of the unsaturated-zone study site 8 and the surrounding rangeland; and $B$, time series of daily precipitation in millimeters and total (matric plus gravimetric) potential in meters for selected depths below land surface (bls) at site 8 (National Oceanic and Atmospheric Administration, 2013). 


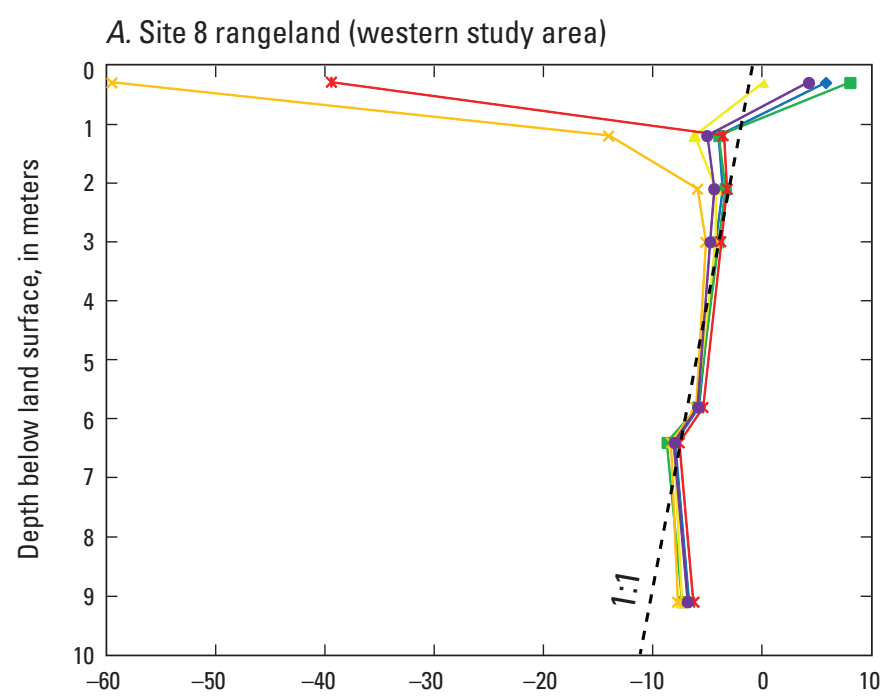

B. Site 1 rangeland (eastern study area)

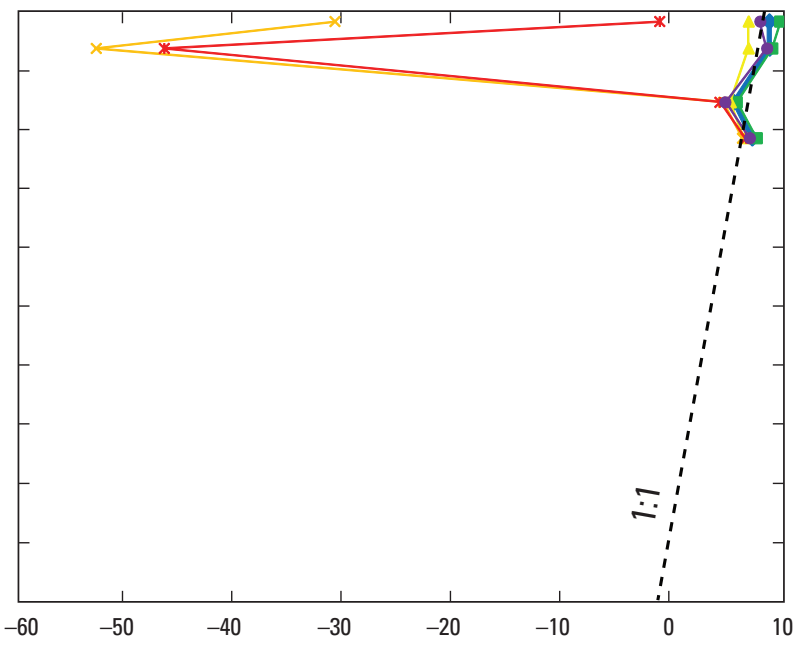

C. Site 6 irrigated corn (western study area)

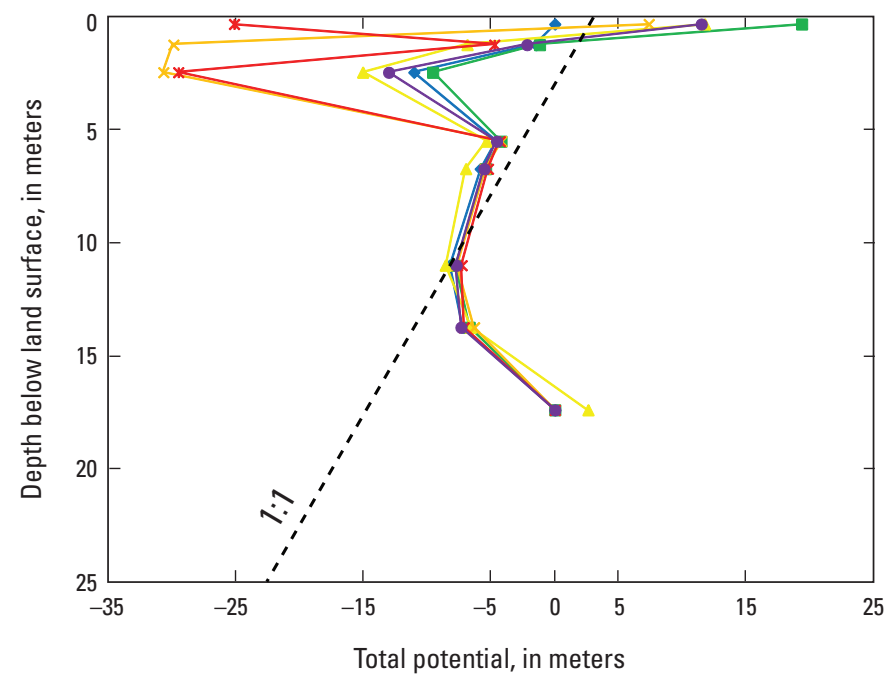

$D$. Site 2 irrigated corn (eastern study area)

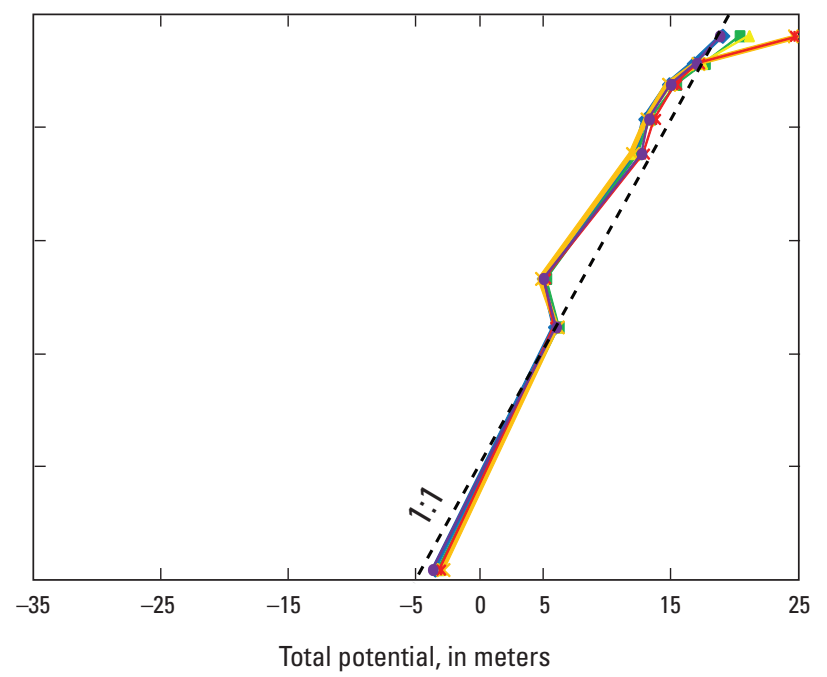

EXPLANATION

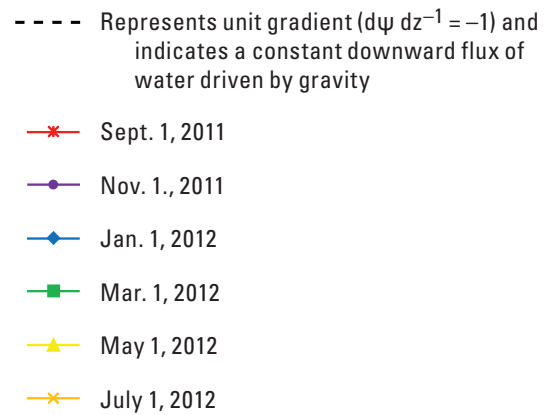

Figure 10. Vertical profiles of total (matric plus gravimetric) potential measured beneath $A$, site 8 ; $B$, site $1 ; C$, site 6 ; and $D$, site 2 on selected days, 2010-12. 


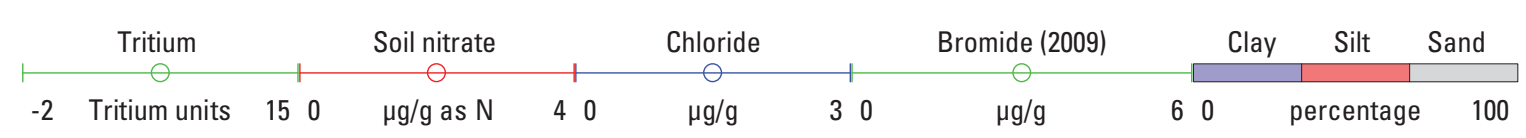

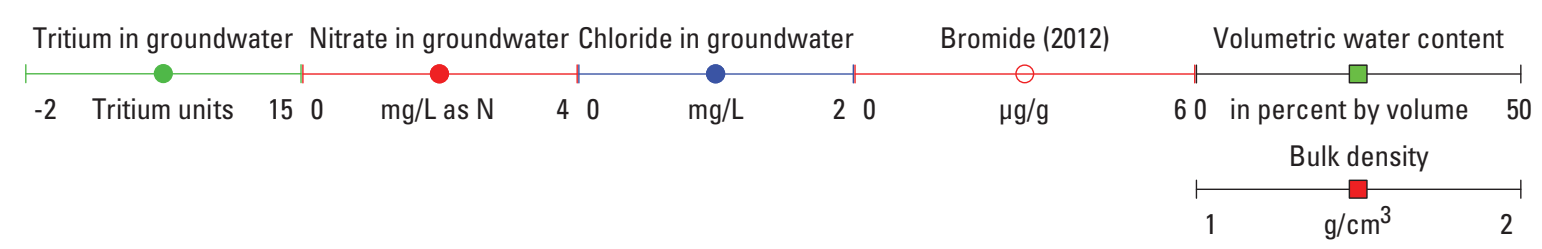

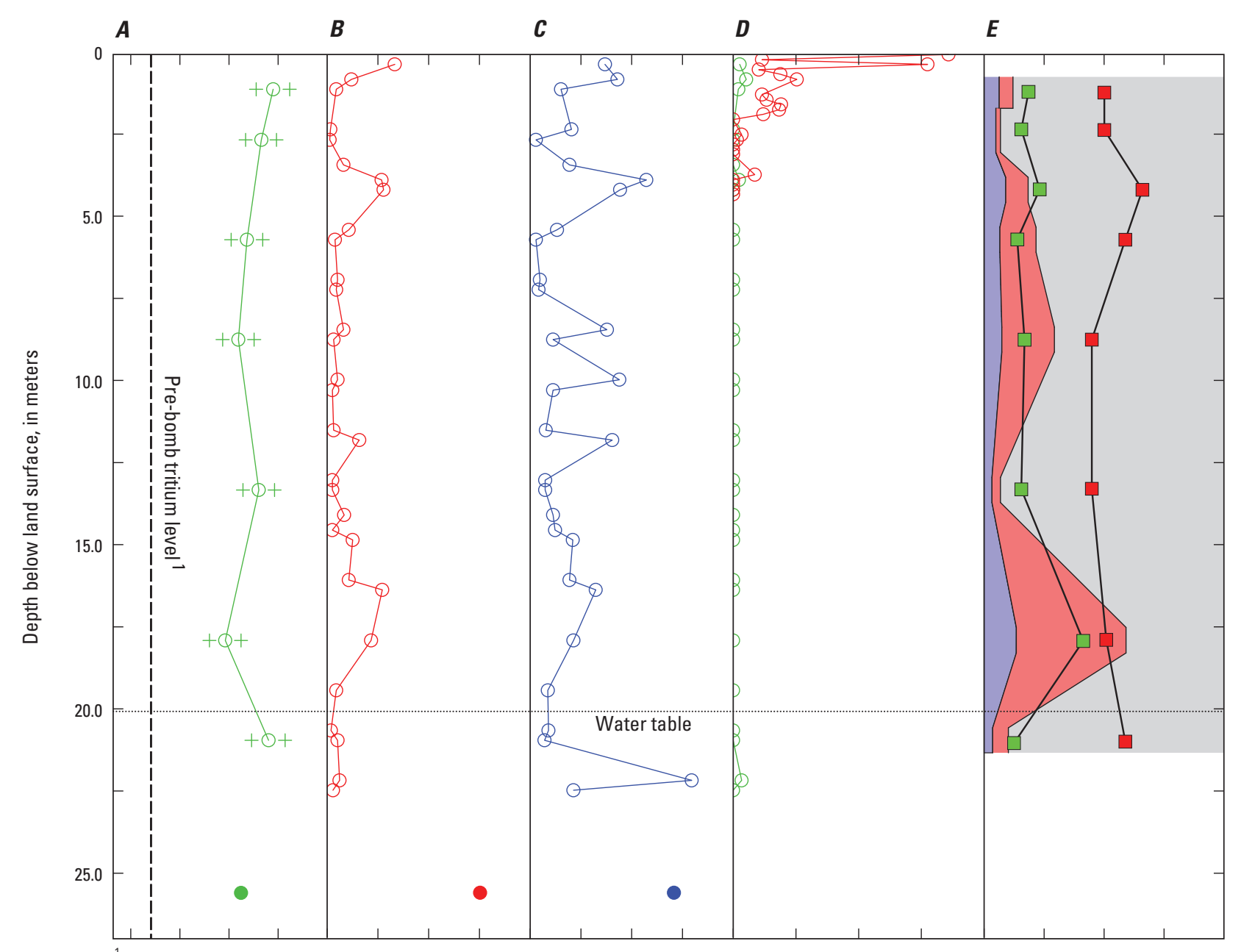

${ }^{1}$ Estimated maximum concentration of pre-bomb tritium in year 2008.

Figure 11. Relation between depth below land surface and $A$, tritium concentrations in soil pore water and groundwater; $B$, nitrate concentrations in soil pore water and groundwater; $C$, chloride concentrations in core sections and cuttings and in groundwater; $D$, bromide concentrations in core sections and cuttings; and $E$, lithology, volumetric-water content, and bulk density from samples collected at site 1 in Central Platte Natural Resources District unsaturated-zone network. 


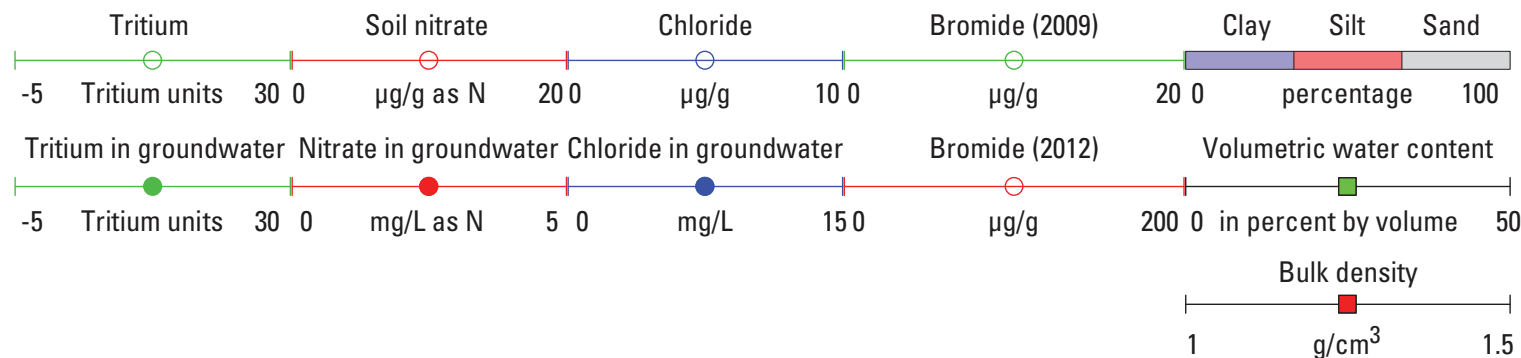

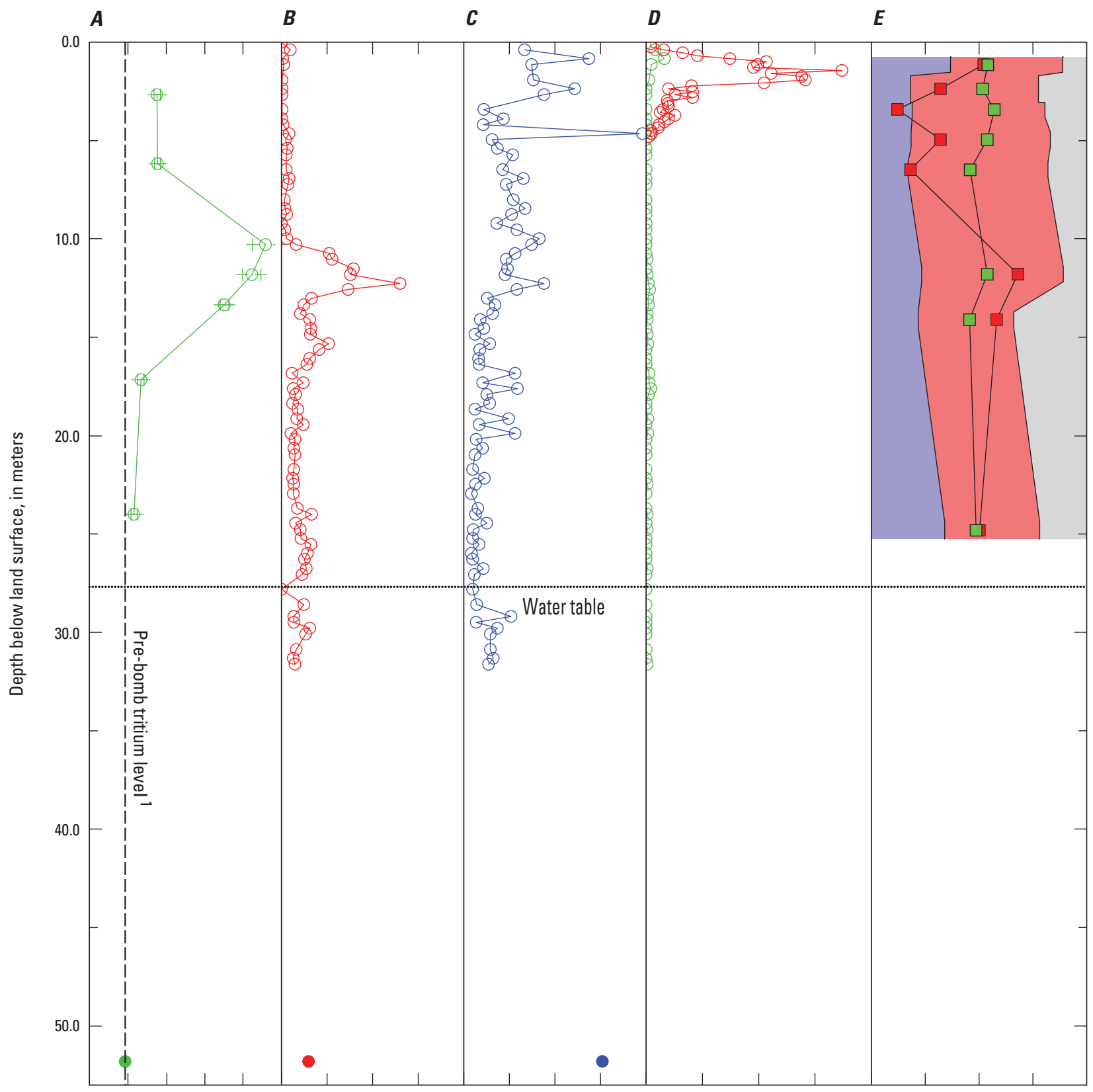

${ }^{1}$ Estimated maximum concentration of pre-bomb tritium in year 2008.

Figure 12. Relation between depth below land surface and $A$, tritium concentrations in soil pore water and groundwater; $B$, nitrate concentrations in soil pore water and groundwater; $C$, chloride concentrations in core sections and cuttings and in groundwater; $D$, bromide concentrations in core sections and cuttings; and $E$, lithology, volumetric-water content, and bulk density from samples collected at site 2 in Central Platte Natural Resources District unsaturated-zone network. 


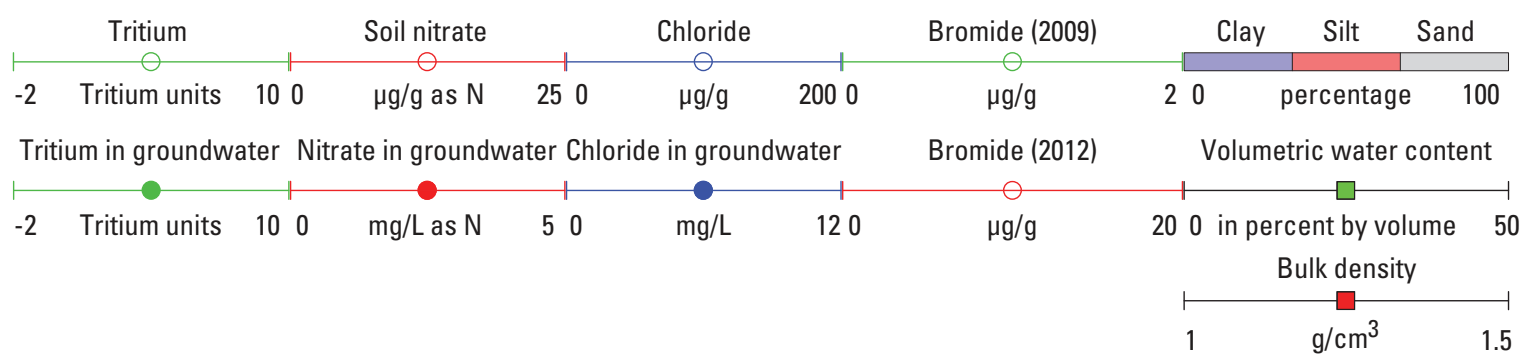

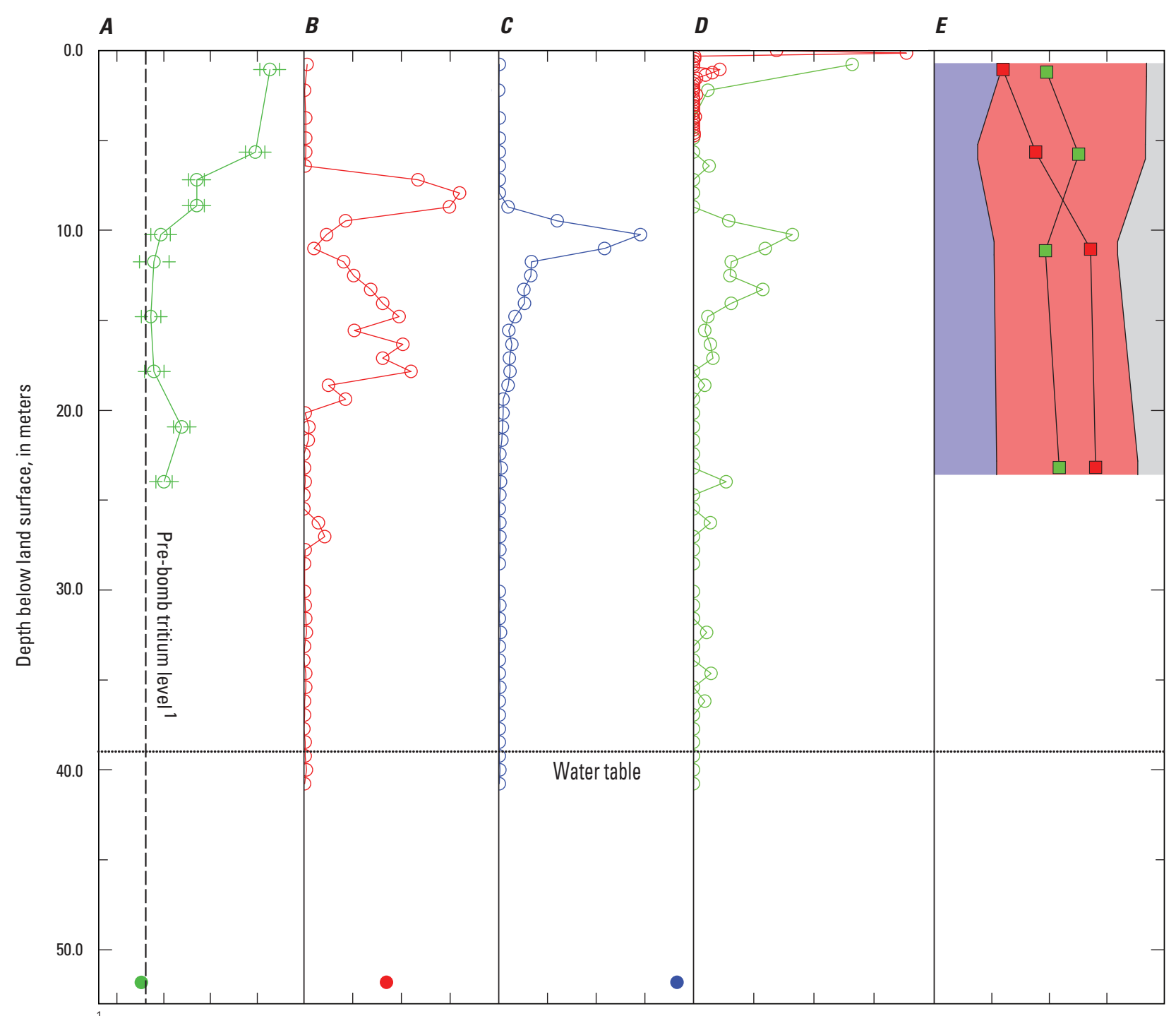

${ }^{1}$ Estimated maximum concentration of pre-bomb tritium in year 2008

Figure 13. Relation between depth below land surface and $A$, tritium concentrations in soil pore water and groundwater; $B$, nitrate concentrations in soil pore water and groundwater; $C$, chloride concentrations in core sections and cuttings and in groundwater; $D$, bromide concentrations in core sections and cuttings; and $E$, lithology, volumetric-water content, and bulk density from samples collected at site 3 in Central Platte Natural Resources District unsaturated-zone network. 


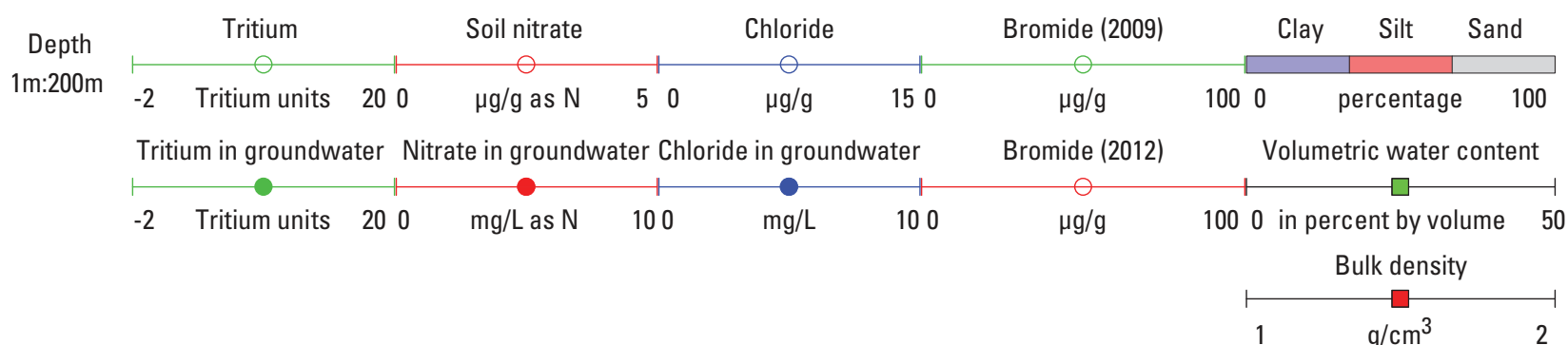

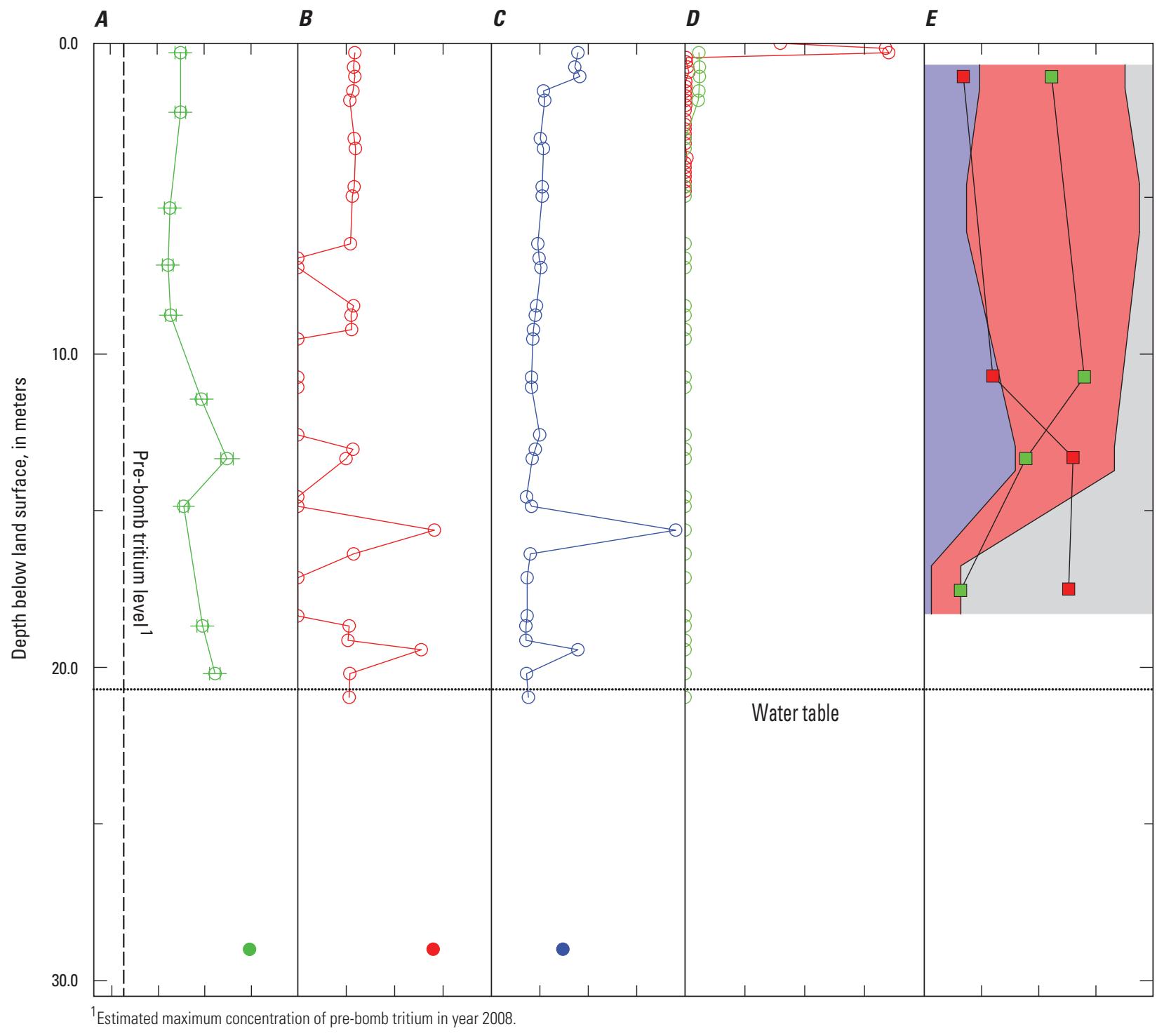

Figure 14. Relation between depth below land surface and $A$, tritium concentrations in soil pore water and groundwater; $B$, nitrate concentrations in soil pore water and groundwater; $C$, chloride concentrations in core sections and cuttings and in groundwater; $D$, bromide concentrations in core sections and cuttings; and $E$, lithology, volumetric-water content, and bulk density from samples collected at site 4 in Central Platte Natural Resources District unsaturated-zone network. 


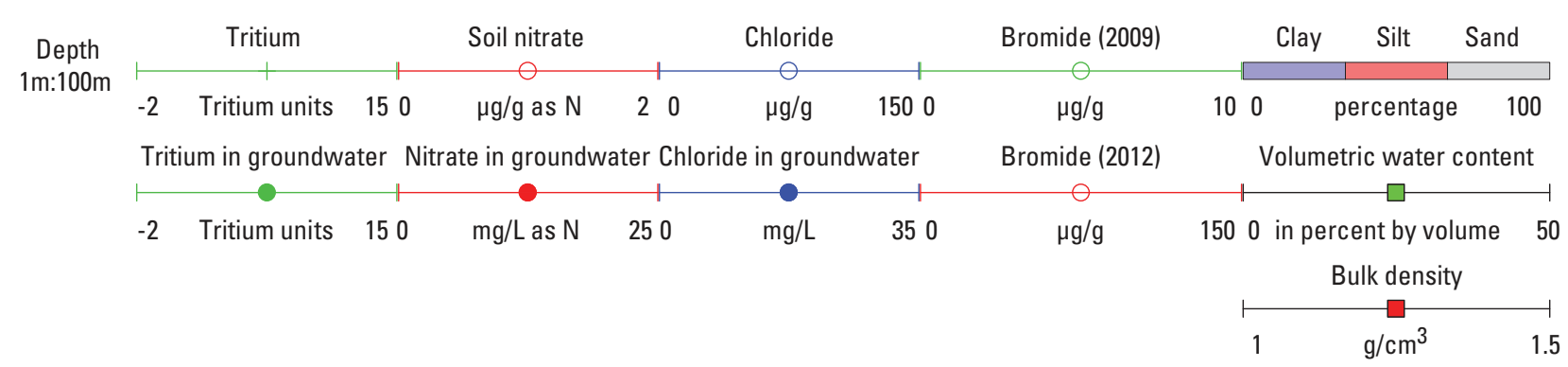

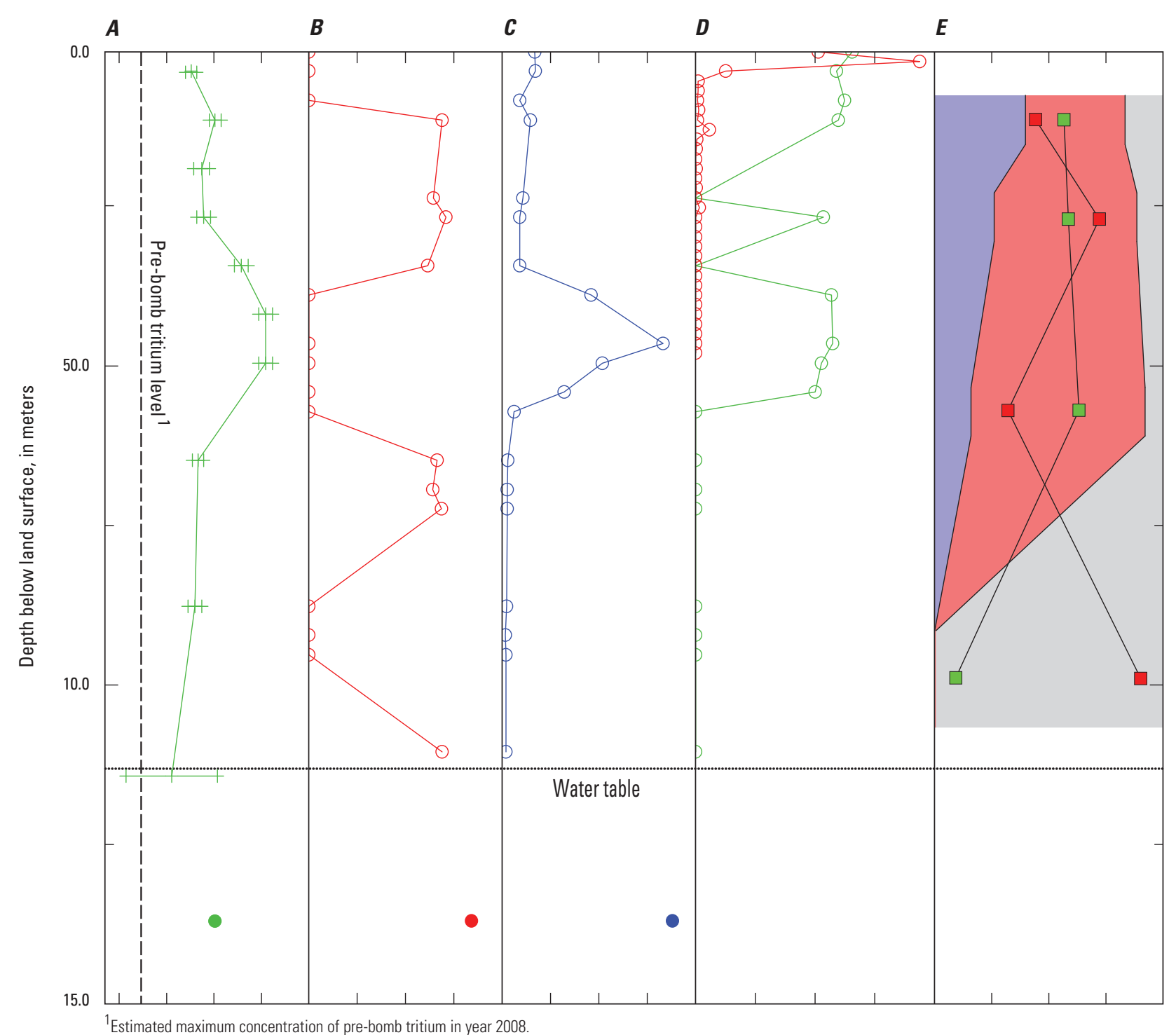

Figure 15. Relation between depth below land surface and $A$, tritium concentrations in soil pore water and groundwater; $B$, nitrate concentrations in soil pore water and groundwater; $C$, chloride concentrations in core sections and cuttings and in groundwater; $D$, bromide concentrations in core sections and cuttings; and $E$, lithology, volumetric-water content, and bulk density from samples collected at site 5 in Central Platte Natural Resources District unsaturated-zone network. 


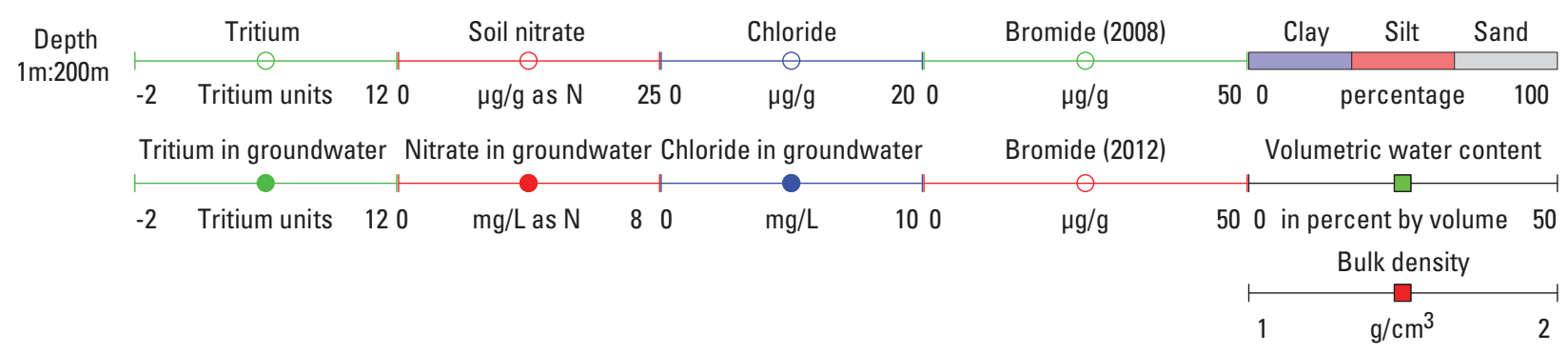

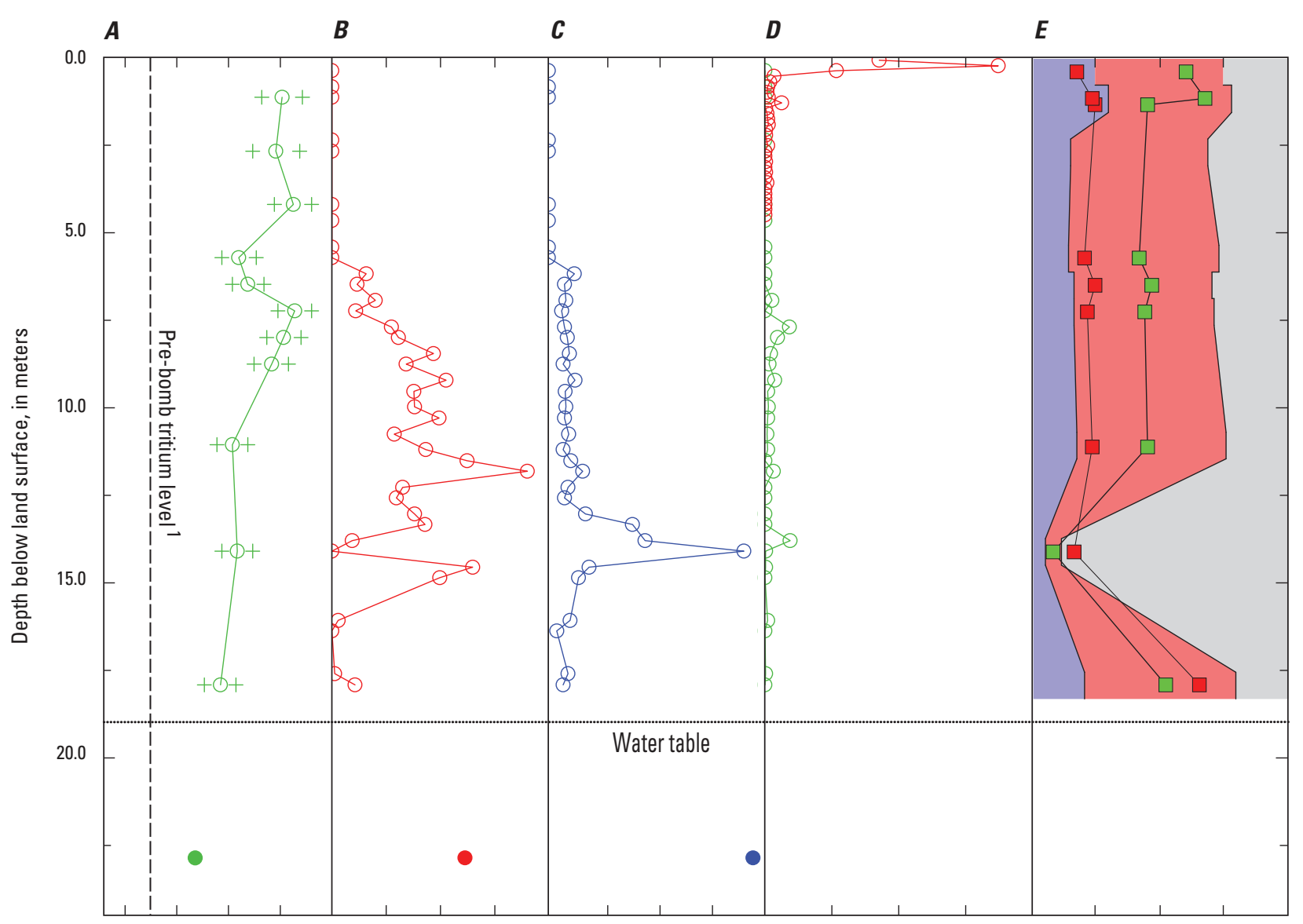

${ }^{1}$ Estimated maximum concentration of pre-bomb tritium in year 2008.

Figure 16. Relation between depth below land surface and $A$, tritium concentrations in soil pore water and groundwater; $B$, nitrate concentrations in soil pore water and groundwater; $C$, chloride concentrations in core sections and cuttings and in groundwater; $D$, bromide concentrations in core sections and cuttings; and $E$, lithology, volumetric-water content, and bulk density from samples collected at site 6 in Central Platte Natural Resources District unsaturated-zone network. 


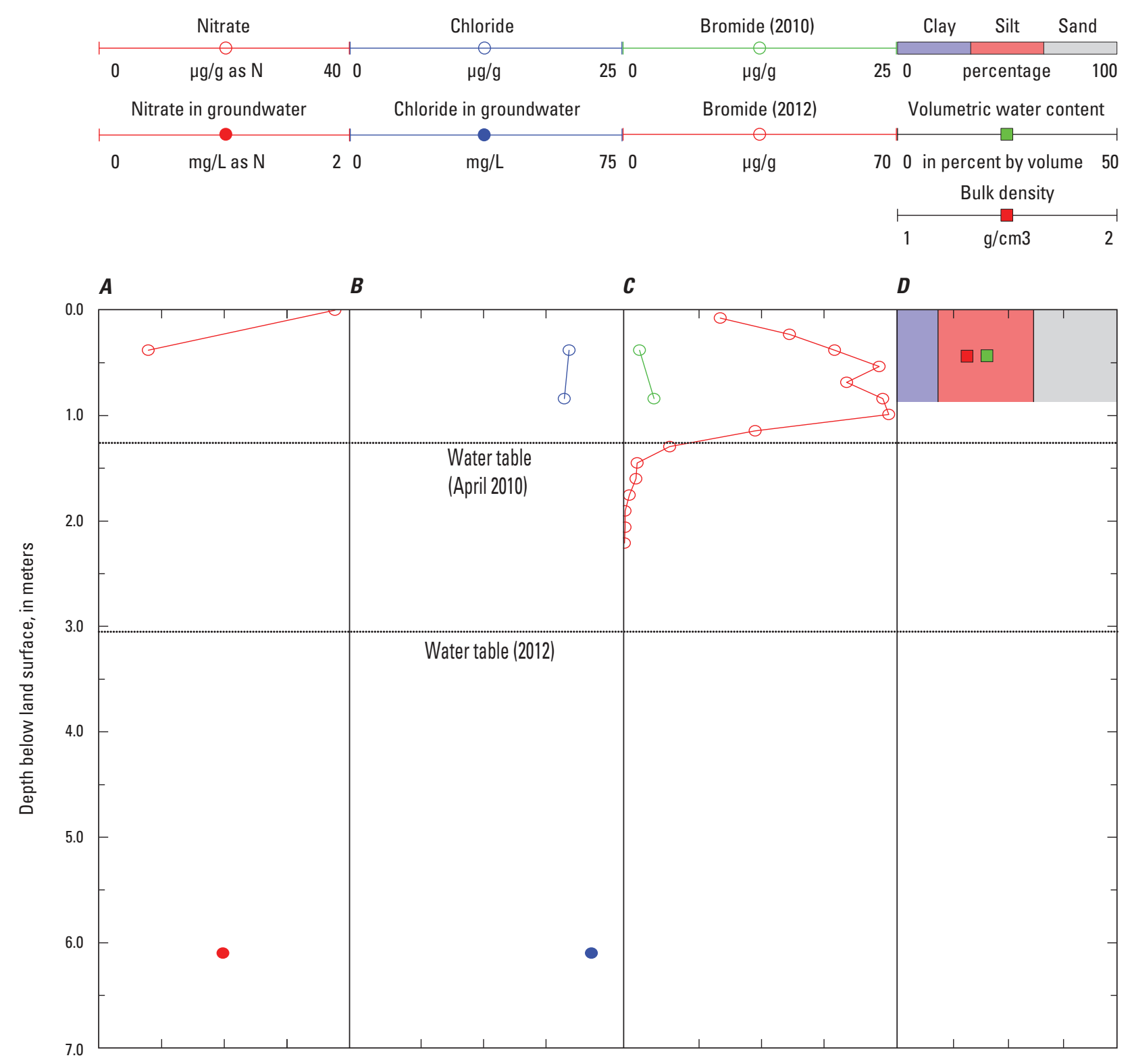

Figure 17. Relation between depth below land surface and $A$, nitrate concentrations in soil pore water and groundwater; $B$, chloride concentrations in core sections and cuttings and in groundwater; $C$, bromide concentrations in core sections and cuttings; and $D$, lithology, volumetric-water content, and bulk density from samples collected at site 7 in Central Platte Natural Resources District unsaturated-zone network. 


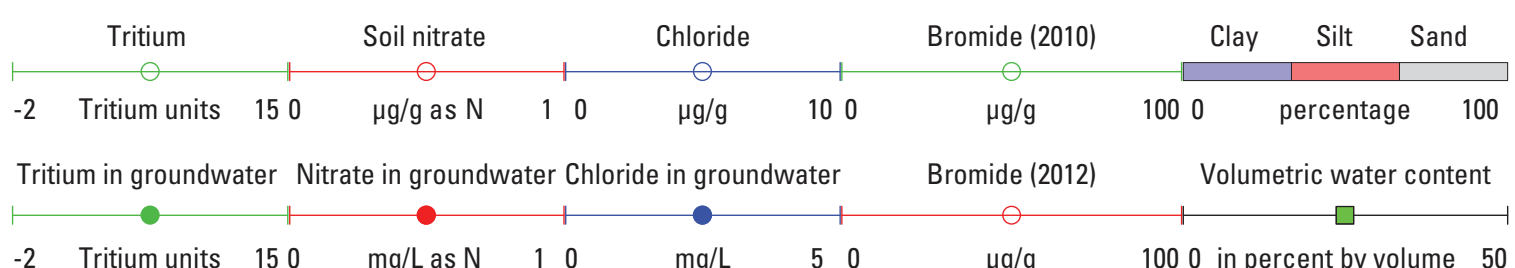

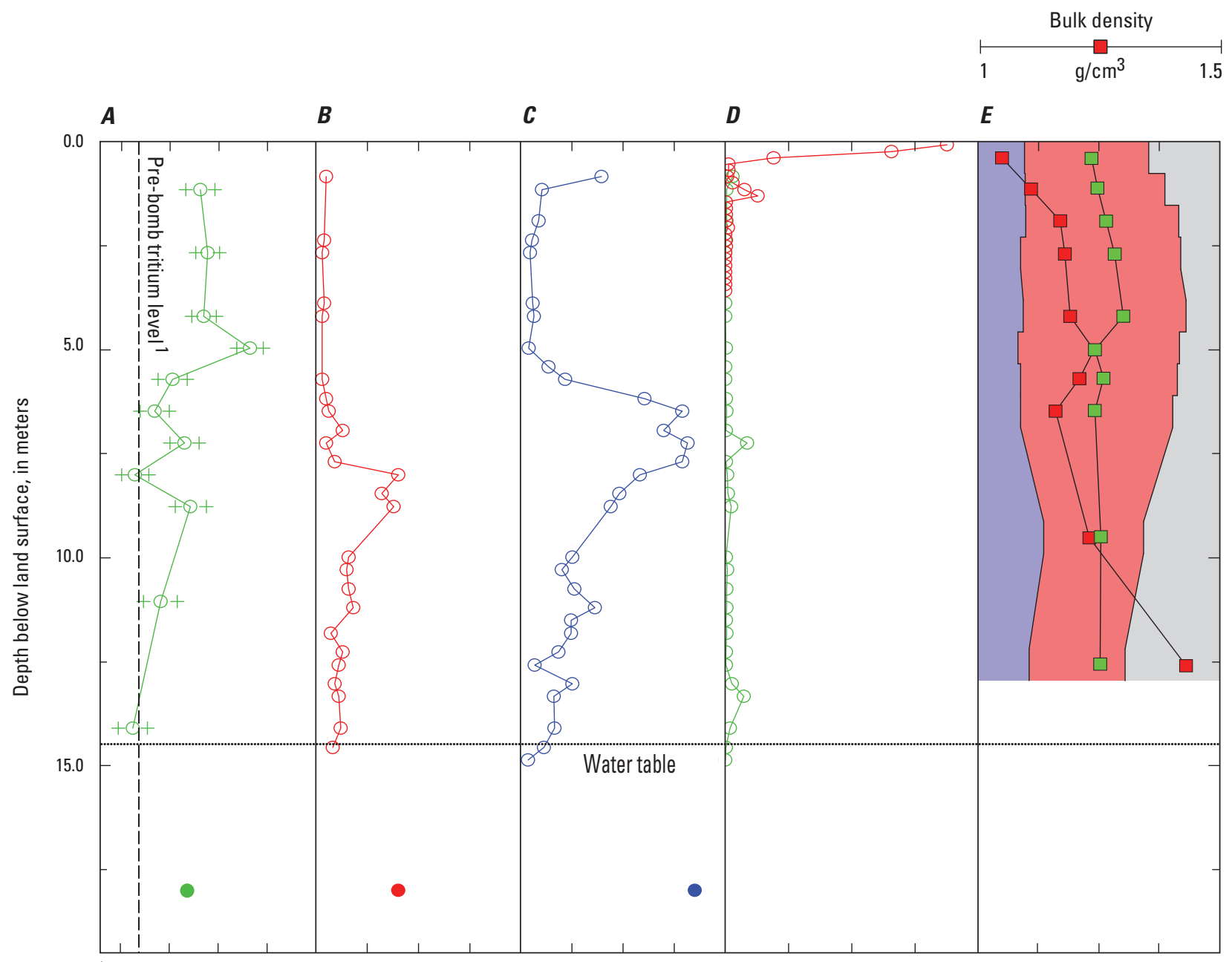

${ }^{1}$ Estimated maximum concentration of pre-bomb tritium in year 2008.

Figure 18. Relation between depth below land surface and $A$, tritium concentrations in soil pore water and groundwater; $B$, nitrate concentrations in soil pore water and groundwater; $C$, chloride concentrations in core sections and cuttings and in groundwater; $D$, bromide concentrations in core sections and cuttings; and $E$, lithology, volumetric-water content, and bulk density from samples collected at site 8 in Central Platte Natural Resources District unsaturated-zone network. 
$\left[\mathrm{mm} / \mathrm{yr}\right.$, millimeter per year; R, recharge; $\varphi$, porosity; $V_{v}^{o}$, modeled groundwater velocity at water table; --, undetermined; >, greater than $]$

\begin{tabular}{|c|c|c|c|c|c|c|c|c|c|c|c|}
\hline \multirow{3}{*}{ Site } & \multicolumn{3}{|c|}{ Tritium $\left({ }^{3} \mathrm{H}\right)$ profile } & \multirow{3}{*}{$\begin{array}{c}\text { Chloride mass- } \\
\text { balance method } \\
\text { Mean (range), } \\
\text { in } \mathrm{mm} / \mathrm{yr}\end{array}$} & \multicolumn{3}{|c|}{ Potassium bromide } & \multicolumn{4}{|c|}{ Age dating } \\
\hline & \multicolumn{2}{|c|}{ Peak displacement (mm/yr) } & \multirow{2}{*}{$\begin{array}{c}\text { Mass } \\
\text { balance } \\
\text { (mm/yr) }\end{array}$} & & \multirow{2}{*}{$\begin{array}{l}\text { Center of } \\
\text { mass } \\
\text { (mm/yr) }\end{array}$} & \multirow{2}{*}{$\begin{array}{l}\text { Peak dis- } \\
\text { placement } \\
\text { (mm/yr) }\end{array}$} & \multirow[b]{2}{*}{$\begin{array}{l}\text { Mean } \\
(\mathrm{mm} / \mathrm{yr})\end{array}$} & \multirow[b]{2}{*}{ Site number } & \multirow{2}{*}{$\begin{array}{c}R=\varphi V_{v}^{o} \\
(\mathrm{~mm} / \mathrm{yr})(\mathrm{ex}- \\
\text { ponential) }\end{array}$} & \multirow{2}{*}{$\begin{array}{c}R=\varphi V_{v}^{o} \\
\text { (mm/yr) } \\
\text { (linear) }\end{array}$} & \multirow{2}{*}{$\begin{array}{c}\text { Mean } \\
R=\varphi V_{V} \\
(\mathrm{~mm} / \mathrm{yr})\end{array}$} \\
\hline & $\begin{array}{l}\text { Bomb } \\
\text { peak }\end{array}$ & $\begin{array}{l}\text { Pre-bomb- } \\
\text { post-bomb } \\
\text { interface }\end{array}$ & & & & & & & & & \\
\hline \multirow[t]{3}{*}{ Site 1} & -- & $>53$ & -- & $21(1.8-96)$ & 38 & 9 & 24 & Site $1-26$ & 25 & 23 & 24 \\
\hline & & & & & & & & Site $1-30$ & 60 & 51 & 56 \\
\hline & & & & & & & & Site $1-35$ & 74 & 56 & 65 \\
\hline \multirow[t]{3}{*}{ Site 2} & 68 & $133-159$ & 137 & -- & 207 & 172 & 190 & Site $2-52$ & -- & -- & -- \\
\hline & & & & & & & & Site 2-61 & -- & -- & -- \\
\hline & & & & & & & & Site $2-70$ & -- & -- & -- \\
\hline \multirow[t]{3}{*}{ Site 3} & -- & 63 & 12 & -- & 171 & 108 & 140 & Site $3-52$ & -- & -- & -- \\
\hline & & & & & & & & Site 3-59 & -- & -- & -- \\
\hline & & & & & & & & Site 3-64 & -- & -- & -- \\
\hline \multirow[t]{3}{*}{ Site 4} & -- & $>80$ & -- & $4.3(1.1-9.6)$ & 109 & 169 & 139 & Site $4-29$ & 14 & 14 & 14 \\
\hline & & & & & & & & Site $4-35$ & -- & -- & -- \\
\hline & & & & & & & & Site $4-44$ & -- & -- & -- \\
\hline \multirow[t]{3}{*}{ Site 5} & -- & $>29$ & -- & -- & 58 & 58 & 58 & Site 5-14 & 35 & 34 & 34 \\
\hline & & & & & & & & Site $5-17$ & 133 & 119 & 126 \\
\hline & & & & & & & & Site $5-20$ & 222 & 182 & 202 \\
\hline \multirow[t]{3}{*}{ Site 6} & -- & $>48$ & -- & -- & 65 & 65 & 65 & Site $6-23$ & 229 & 220 & 224 \\
\hline & & & & & & & & Site 6-27 & 305 & 283 & 294 \\
\hline & & & & & & & & Site 6-30 & 108 & 97 & 102 \\
\hline \multirow[t]{3}{*}{ Site 7} & -- & -- & -- & -- & 256 & 394 & 325 & Site 7-6 & 86 & 80 & 83 \\
\hline & & & & & & & & Site 7-11 & 202 & 172 & 187 \\
\hline & & & & & & & & Site 7-14 & 304 & 239 & 272 \\
\hline \multirow[t]{2}{*}{ Site 8} & -- & 53 & 10 & $13(1.1-68)$ & 35 & 201 & 118 & Site $8-18$ & 35 & 33 & 34 \\
\hline & & & & & & & & Site 8-24 & 125 & 101 & 113 \\
\hline
\end{tabular}


Daily time series of $\psi_{T}$ at sites 3-5 are not presented herein because most of the HDPs at these three sites produced $\psi_{m}$ values that are outside of measurement range, which indicates that the HDPs never reached equilibrium with the native sediments. It is likely that most HDPs at sites 3-5 remained saturated and never equilibrated, as suggested by the reasonably high percentage of clay and silt in the UZ and by the use of water by the drillers to soften the soil during drilling the bore holes at those sites. Additionally, during installation of the HDPs at sites 3-5, the HDPs and surrounding silica flour were installed with more deionized water than at the other sites, which, combined with the drilling fluids and the high percentage of clay and silt, may have prevented equilibrium.

\section{Total Water Potentials}

Daily time series of total potential $\left(\psi_{T}\right)$ at various depths beneath sites 1,2 , and 6-8 and daily precipitation are shown in figures 5-9. Most of the HDPs required weeks, or months in some cases, to reach equilibrium with the native sediments. Once equilibrated, the daily time series of $\psi_{T}$ contain important information about the controls on the direction and rate of water movement in the UZ. Real-time and historical data can be accessed by using the 15-digit USGS site at the following link: http://waterdata.usgs.gov/ne/nwis/gw, accessed February $6,2013$.

After the initial equilibration period at sites 1,2, and 6-8, the magnitude of temporal variability in the $\psi_{T}$ time series is a function of depth in the UZ (figs. 5-9). From land surface to about $2 \mathrm{~m}$ below land surface (bls), most $\psi_{T}$ time series have considerably greater variability than those $\psi_{T}$ time series at depths greater than about 1 to $2 \mathrm{~m}$ bls, which generally represents the maximum depth of the root zone (figs. 5-9). At most sites, the HDP closest to land surface generally recorded the greatest site-specific, temporal variability in $\psi_{T}$ values. The decreasing temporal variability in the $\psi_{T}$ time series as a function of depth illustrates how the UZ at each site acts as a filter that dampens magnitude and smooths abruptness of time-varying atmospheric signals from local precipitation and air temperature. The local precipitation and air temperature affects evapotranspiration and infiltration that cause reasonably large, temporal variability of the $\psi_{T}$ values in the near surface compared to greater depths in the UZ profile.

The temporal variability of the $\psi_{T}$ values in the near surface creates transient vertical gradients in $\psi_{T}$ that partially control the direction and magnitude of water flux, including the downward propagation of wetting fronts in the UZ. To illustrate the transient nature of the vertical gradients, the $\psi_{T}$ profiles are shown for selected days from the complete record of $\psi_{T}$ time series at sites 1, 2, 6, and 8 for years 2010-12 (fig. 10). Water in the UZ moves from large to small $\psi_{T}$ values. The transient vertical gradients in $\psi_{T}$ generate periodic wetting fronts that reach various depths at the sites (figs. 5-9). The wetting fronts generally are characterized in the $\psi_{T}$ time series as reasonably abrupt and sharp increases in the $\psi_{T}$ values that indicate the start of the wetting phase, followed by a slower decrease in $\psi_{T}$ values that indicate the drying phase during drainage (figs. 5-9). The propagation of the wetting fronts is similar to the movement of a wave down the UZ profile because as the wetting and drying cycle reach a given depth, subsequent precipitation or irrigation, or both, pushes the wetting front deeper into the profile, further propagating the wave-like wetting and drying cycle at subsequently deeper depths in the UZ profile. An example of the wave-like propagation was observed at site 2 (irrigated corn) in response to precipitation during late January and early February 2011 (fig. 6). A wetting front that reached $2.1 \mathrm{~m}$ bls on February 10 arrived about 7 days later (February 17) at least $6.1 \mathrm{~m}$ bls (fig. 6). Similarly rapid and propagating wetting fronts have been observed in other parts of the northern High Plains aquifer in western Nebraska and eastern Colorado, in the southern High Plains aquifer in Texas (Gurdak and others, 2007), and in other aquifers in semiarid and arid climates (Rimon and others, 2007, 2011). Rimon and others $(2007,2011)$ used a different UZ monitoring design than did this study and observed similarly rapid, propagating wetting fronts that, for example, reached $6.3 \mathrm{~m}$ bls in less than 1 week. Rimon and others (2011) suggest that the rapidly propagating wetting fronts may be explained using a porescale, dual-domain flow conceptual model. Dual-domain flow refers to the coexistence of matrix and preferential flow as governing mechanisms controlling the percolation process in the unsaturated zone (Rimon and others, 2011).

Although the installation depths of the HDPs vary at each site, the mean maximum depth of propagation of the wetting fronts is greater beneath irrigated agricultural sites (at least $6.1 \mathrm{~m}$ at site 2 , and $2.4 \mathrm{~m}$ at site 6 ; mean $=4.3 \mathrm{~m}$ ) than beneath the corresponding eastern and western rangeland sites $(1.5 \mathrm{~m}$ at site 1 , and $3 \mathrm{~m}$ at site 8 ; mean $=2.3 \mathrm{~m}$ ) (figs. 6, 7, and 9). The $\theta$ also is generally greater beneath the irrigated agricultural sites than the corresponding rangeland sites, particularly in the upper $1.5 \mathrm{~m}(150 \mathrm{~cm})$ bls $(2012$ mean of about 33 percent at site 2, 20 percent at site $6,8.2$ percent at site 1 , and 12 percent at site 8 ; table 3 ). The variability in the mean maximum wetting-front depths beneath the irrigated agricultural sites and rangeland sites likely are related to site-specific antecedent moisture and $\psi_{T}$ conditions that are controlled in part by native vegetation, irrigation practices on crops, and natural variability in precipitation frequency and intensity (Gurdak and others, 2007). A common characteristic of all the sites is that with depth, the large storage capacity of the UZ leads to dampening of the temporal variability in the $\psi_{T}$ values and the intensity of wetting fronts such that there is a more nearly constant downward potential gradient at depth (fig. 10).

Below the root zone, there is less temporal variability in the $\psi_{T}$ values, and the $\psi_{T}$ profiles at some sites generally show a decrease in $\psi_{T}$ with depth (fig. $10 A, B, D$ ). The $\psi_{T}$ profiles below the root zone at sites 1,2 , and 8 are close to unit gradient $\left(d \psi d \mathrm{z}^{-1}=-1\right)$ (figs. $\left.10 A, B, D\right)$, which indicates a constant downward flux of water driven by gravity (Healy, 2010). The downward $\psi_{T}$ gradient below the root zone is apparent at all sites except the irrigated corn site 6 (fig. 10C) and near the 
bottom of the profile at the rangeland site 8 (fig. 10A). The $\psi_{T}$ profile beneath site 6 approaches unit gradient between approximately 5 and $12 \mathrm{~m}$ bls, but the profile has an upward gradient at depths greater than $12 \mathrm{~m}$ bls. The upward $\psi_{T}$ gradient prevents downward movement of water and may indicate a transient condition or a zone of lateral flow. The upward $\psi_{T}$ gradient likely is caused by a combination of the substantial increase in the percentage of sand from approximately 12 to $15 \mathrm{~m}$ bls (fig. 16) and fluctuations in the water table and corresponding capillary rise that increase the $\psi_{T}$ values deeper in the UZ profile (fig. 10C). Water flux generally decreases when the wetting front reaches a boundary between soil textures (Tindall and Kunkel, 1999).

The transient nature of the $\psi_{T}$ gradient in the near-surface interval and the more nearly constant downward $\psi_{T}$ gradient at depth produce characteristic patterns in the $\psi_{T}$ profile as a general function of the land use or cover type and east-west gradient in mean annual precipitation. Beneath rangeland (sites 1 and 8; fig. $10 A-B$ ), the $\psi_{T}$ profiles have considerably more near-surface variability than those beneath irrigated corn fields (sites 2 and 6; fig. 10C-D). During summer (July) and fall (September), the $\psi_{T}$ values became negative and created upward $\psi_{T}$ gradients beneath the rangeland sites (fig. 10A-B) that are less pronounced (site 6) or nonexistent (site 2) beneath the irrigated corn sites (fig. 10C-D). In general, the application of irrigation water has the effect of reducing the near-surface variability of $\psi_{T}$ values and creating a more constant downward $\psi_{T}$ gradient throughout the UZ profile. The effect of the east-west contrast in mean annual precipitation on $\psi_{T}$ gradients is most evident beneath the irrigated corn (sites 2 and 6). The temporal variability in $\psi_{T}$ values beneath site 6 (western, drier part of the study area) is much greater than beneath site 2 (eastern, wetter part of the study area) and resembles the temporal variability in $\psi_{T}$ profiles beneath the rangeland, particularly during the summer (July) and fall (September) (fig. 10C). Site 2 has little temporal variability in $\psi_{T}$ values compared to beneath site 6 .

\section{Tritium Profiles}

Water flux was calculated using ${ }^{3} \mathrm{H}$ concentrations in soil water with two different methods. The peak-displacement method was discussed briefly in the "Introduction" section of this report and is described in equation 3. Depending on the interpretation of the ${ }^{3} \mathrm{H}$ profiles, either the depth of the ${ }^{3} \mathrm{H}$ peak or the pre-bomb/post-bomb interface was used for $z_{q}$. The pre-bomb/post-bomb interface was estimated as $0.3 \mathrm{~T}^{q^{\prime}} \mathrm{U}$ and is shown as a vertical dashed line in figures 11 through 16 and 18. Several meters can exist between ${ }^{3} \mathrm{H}$ samples increasing the uncertainty of $z_{q}$; a range of values for fluxes was computed to bracket estimated flux rates. As mentioned in the "Introduction" section, the peak displacement method assumes that movement in the UZ is dominated by piston flow (Izbicki and others, 2002), where flow lines in the UZ are uniform and mixing is minimal.
Tritium profiles for all sites are presented in figures 11 through 16 and 18 . No ${ }^{3} \mathrm{H}$ data were collected at site 7 because at the time of sampling the UZ thickness was slightly greater than $1 \mathrm{~m}$, which is not adequately thick enough for ${ }^{3} \mathrm{H}$-based recharge methods. Generally, post-bomb ${ }^{3} \mathrm{H}$ levels had flushed through the entire profile at sites 1, 4, 5, and 6 . Recharge at these sites was considered modern (within 10 years of sampling). The flushing of the UZ at each of these sites may have happened for a variety of reasons. Site 1 was located in a rangeland area adjacent to a minimally maintained county road without a distinct structured road ditch. Furthermore, site 1 was underlain by roughly $20 \mathrm{~m}$ of well-drained, eolian fine sand. Sites 2 and 3 were located in the upland area with at least $48 \mathrm{~m}$ of loess overlying the Ogallala. Site 2 lies between two irrigated corn fields, whereas site 3 lies adjacent to a dryland corn field. Both were remote from any obvious sources of focused recharge, such as road ditches or ponds. Site 4 was located in a narrow draw bounded by two hillslopes, and site 5 was located near a road ditch where ponding may take place after heavy precipitation events. Thus, local topography at sites 4 and 5 would facilitate focused recharge at each site. Site 6 was located about $30 \mathrm{~m}$ from the road, in the fencing median between two irrigated corn fields. Site 6 was remote from any areas of obvious focused recharge. The UZ at sites 5 and 6 most likely was flushed from the application of irrigation water above a reasonably shallow water table (less than $20 \mathrm{~m})$.

In contrast to the sites where the UZ pore water was permeated by post-bomb levels of ${ }^{3} \mathrm{H}$, three sites contained measurable pre-bomb levels of ${ }^{3} \mathrm{H}$. Site 8 was located in a rangeland area about $25 \mathrm{~m}$ from the road. Site 8 also lies in close proximity (within about $250 \mathrm{~m}$ ) to the backwater of CPNRD reservoir B-1 that might provide some lateral focused recharge during years that the reservoir is filled to capacity [average capacity of $2.5 \times 10^{6}$ cubic meters $\left(\mathrm{m}^{3}\right)$ took place most recently in 2001, 2002, 2004, 2007, 2010, and 2012]. In 2012, there was little natural flow available, and reservoir B-1 received total deliveries of only $2.6 \times 10^{5} \mathrm{~m}^{3}$ (Duane Woodward, Central Platte Natural Resources District, written commun., 2013).

Site 7 was located in the Platte River valley adjacent to a road ditch, a setting similar to site 5 . Site 7 also lies about 400 m north of the Dawson County Canal, which was shown to have affected groundwater levels (fig. 3). At site 7, depths to groundwater generally are less than $1 \mathrm{~m}$ to $3.3 \mathrm{~m}$, so ${ }^{3} \mathrm{H}$ data were not collected at that site.

Flushing the UZ of soil water containing pre-bomb levels of ${ }^{3} \mathrm{H}$ also was evidenced by concentrations of ${ }^{3} \mathrm{H}$ greater than the pre-bomb concentration of $0.3 \mathrm{TU}$ in the shallow groundwater at sites $1,4,5$, and 6 . This precludes the use of either water-flux calculation method to determine the apparent recharge date of the groundwater. Although quantitative estimates of recharge rates could not be determined with the ${ }^{3} \mathrm{H}$ data, a minimum flux can be calculated using equation 3 by substituting the depth to water for $z_{q}$. The minimum flux estimates determined from ${ }^{3} \mathrm{H}$ profiles for sites $1,4,5$, and 6 are presented in table 4 . Minimum fluxes were estimated as 
greater than $(>) 53$ to $>80$ millimeters per year $(\mathrm{mm} / \mathrm{yr})$ for the two rangeland sites (sites 1 and 4 ) and $>29$ to $>48 \mathrm{~mm} / \mathrm{yr}$ for the two irrigated agricultural sites (sites 5 and 6).

A discernible post-bomb peak concentration of $27 \mathrm{TU}$ was detected at site 2 at a depth of $10.2 \mathrm{~m}$ (fig. 12), which indicates a substantial component of the water at this depth interval was meteoric during the 1960s or 1970s (Clark and Fritz, 1997). Using equation 3 and a depth-averaged $\theta$, the estimated water flux was $68 \mathrm{~mm} / \mathrm{yr}$. The ${ }^{3} \mathrm{H}$ concentration of shallow groundwater beneath site 2 was $0.1 \mathrm{TU}$ and is considered pre-bomb water. The ${ }^{3} \mathrm{H}$ profile (fig. 12) indicates that the pre-bomb ${ }^{3} \mathrm{H}$ level of $0.3 \mathrm{TU}$ was not reached; however, ${ }^{3} \mathrm{H}$ concentrations decreased sharply in sampled intervals below the one corresponding to the observed post-bomb peak. If it is assumed that the pre-bomb/post-bomb interface was reached below the deepest sample and above the water table, then the calculated flux would be 133 to $159 \mathrm{~mm} / \mathrm{yr}$. The range in flux estimates between the post-bomb peak method and pre-bomb/ post-bomb interface method suggests preferential flow may exist in the UZ. A flux of $137 \mathrm{~mm} / \mathrm{yr}$ was calculated using the mass-balance method. This estimate may be more appropriate because this method estimates fluxes independent of the effects of preferential flow in the UZ. Preferential flow was reported in loess deposits approximately $200 \mathrm{~km}$ northeast of the study area, where pesticide compounds were detected $7 \mathrm{~m}$ beneath cropland (Hancock and others, 2008).

A pre-bomb/post-bomb interface was detected at site 3 at a depth of $15 \mathrm{~m}$ (fig. 13). Using equation 3 and the depthaveraged $\theta$, the estimated water flux is $63 \mathrm{~mm} / \mathrm{yr}$. Larger concentrations of ${ }^{3} \mathrm{H}$ (as many as $2.5 \mathrm{TU}$ ) were measured below this leading edge; however, ${ }^{3} \mathrm{H}$ concentration in shallow groundwater beneath site 3 was $0 \mathrm{TU}$ and this is considered to be pre-bomb water. It is plausible that the moderately elevated ${ }^{3} \mathrm{H}$ levels below the pre-bomb/post-bomb interface may be the result of local preferential flow in the UZ as was suggested to be likely at site 2 . An estimate of $12 \mathrm{~mm} / \mathrm{yr}$ was calculated using the mass-balance method.

At site 8, the pre-bomb/post-bomb interface was interpreted to be at $14 \mathrm{~m}$ bls (fig. 18). Using equation 3 and the depth-averaged $\theta$, the estimated water flux is $53 \mathrm{~mm} / \mathrm{yr}$.

Concentration of ${ }^{3} \mathrm{H}$ in shallow groundwater here was $4.3 \mathrm{TU}$, which is an order of magnitude greater than pre-bomb ${ }^{3} \mathrm{H}$ concentrations. The elevated ${ }^{3} \mathrm{H}$ concentration in groundwater most likely was caused by seepage from flood-control reservoir B-1 (not shown on map) that, when full, is located approximately $250 \mathrm{~m}$ east of the site. An estimated water flux of $10 \mathrm{~mm} / \mathrm{yr}$ was calculated using the mass-balance method.

The calculated flux using the mass-balance method with data from site 2 is 11 to 14 times greater than that beneath sites 3 (dryland) or 8 (rangeland). This comparison indicates that irrigation may be an important factor affecting water fluxes in the UZ. The fluxes reported for the post-bomb peakdisplacement method indicate similar rates across the study area; however, differences exist between sites 2 and 3 when compared to site 8 , which may be the result of the east-west precipitation contrast.

\section{Chloride Profiles}

Vertical profiles of $\mathrm{Cl}^{-}$concentrations contain important information about the sources of $\mathrm{Cl}^{-}$and water movement in the UZ beneath each site, and results for all eight study sites are shown in figures 11-18. At all sites except sites 3 and 5, the concentrations of $\mathrm{Cl}^{-}$in soil profiles were generally less than $10 \mu \mathrm{g} / \mathrm{g}$. At sites 4 and 6 , peak concentrations of $\mathrm{Cl}^{-}$ exceeded $10 \mu \mathrm{g} / \mathrm{g}$ at approximately $15 \mathrm{~m}$ bls (figs. 14 and 16). The $\mathrm{Cl}^{-}$profiles at sites 3 and 5 are much different than the other sites because the concentrations generally are greater than $10 \mu \mathrm{g} / \mathrm{g}$ and have peak concentrations that exceed 140 and $120 \mu \mathrm{g} / \mathrm{g}$, respectively (figs. 13 and 15). The $\mathrm{Cl}^{-}$enrichment and large peak concentrations beneath sites 3 and 5 may reflect a combination of historical land use and possibly a geologic source from the reasonably large percentage of silt and clay at similar depths as the peaks; however, because similar loess is present beneath other sites with much smaller $\mathrm{Cl}^{-}$profile concentrations, the $\mathrm{Cl}^{-}$enrichment and large peaks at sites 3 and 5 are most likely the function of historical land use. The large peaks at sites 3, 4, 5, and 6 might represent incompletely flushed $\mathrm{Cl}^{-}$that accumulated before the onset of irrigation, past agricultural-chemical applications containing $\mathrm{Cl}^{-}$such as $\mathrm{KCl}$, large concentrations of $\mathrm{Cl}^{-}$, or both, that are present in the irrigation water used at site 5 . The road ditch near site 5 may have also helped focus water with large concentrations of $\mathrm{Cl}^{-}$from chemical applications, irrigation water, or possibly the spill or release of $\mathrm{Cl}^{-}$containing substances from or on the adjacent road.

In contrast to the study area, the more arid regions of the High Plains aquifer, such as in Texas and southern Kansas, have strong upward $\psi_{T}$ gradients in the UZ created from water uptake by the plant roots and subsequent upward movement of water vapor, which has created naturally occurring soil reservoirs with often large (100s to $1,000 \mathrm{~s} \mathrm{mg} / \mathrm{L}$ ) concentrations of $\mathrm{Cl}^{-}$and $\mathrm{NO}_{3}{ }^{-}$in pore water immediately below the root zone (McMahon and others, 2003, 2006; Gurdak and others, 2007). These large, naturally occurring $\mathrm{Cl}^{-}$and $\mathrm{NO}_{3}^{-}$reservoirs resulting from enrichment by evapotranspiration can be mobilized and transported downward toward the water table by the conversion of rangeland to irrigated and dryland agricultural land (McMahon and others, 2006) and episodic precipitation events (Gurdak and others, 2007). As discussed previously, the $\psi_{T}$ gradients at sites 1, 2, and 6-8 (figs. 5-9) are generally downward and would not have created large reservoirs of $\mathrm{Cl}^{-}$ and $\mathrm{NO}_{3}{ }^{-}$in pore water; however, the rangeland sites 4 and 8 have a considerable peak of $\mathrm{Cl}^{-}$at approximately 16 and $7 \mathrm{~m}$ bls, respectively. Although much smaller in concentrations than those present in pore water beneath the more arid regions of the High Plains aquifer, the peaks beneath rangeland sites 4 and 8 may represent incompletely flushed $\mathrm{Cl}^{-}$that accumulated from enrichment by evapotranspiration during reasonably drier periods or droughts at these sites. As explained below in the "Nitrate Profiles" section, the drier period that may have caused the enrichment likely occurred sometime since the 1960s and was a transient condition of substantially 
shorter duration than the arid conditions on the High Plains of Texas or southern Kansas. No apparent $\mathrm{Cl}^{-}$peak is present beneath site 1 (rangeland), which indicates that $\mathrm{Cl}^{-}$did not accumulate in large concentrations nor did recent water movement flush out any accumulated $\mathrm{Cl}^{-}$peak that would have been comparable to the peak beneath site 4 or 8 . Both explanations are consistent with greater mean annual precipitation at site 1 than corresponding rangeland site 8 that is located in the drier part of the study area than rangeland site 1 . The $\mathrm{Cl}^{-}$ peaks beneath rangeland sites 4 and 8 are an order of magnitude smaller than peak concentrations beneath sites 3 and 5 , and indicate that the $\mathrm{Cl}^{-}$beneath sites 3 and 5 is largely from anthropogenic sources. The $\mathrm{Cl}^{-}$peak beneath site 6 (irrigated) is similar in magnitude and depth to the peak beneath site 4 (rangeland) and may indicate a naturally occurring source of $\mathrm{Cl}^{-}$that has been mobilized and transported by water movement to approximately $14 \mathrm{~m}$ bls because of the conversion of rangeland to irrigated agriculture.

Using equation 2 , the authors estimated water fluxes at sites 1, 4, and 8. The $\mathrm{Cl}^{-}$concentrations measured in the cores were used for $c_{\mathrm{Cl}}$ because the cores had associated gravimetric water-content data needed to convert $\mathrm{Cl}^{-}$concentrations from micrograms per gram to grams per cubic meter. Values for $q_{C l}$ were approximated as the product of the mean annual precipitation rate and the concentration of $\mathrm{Cl}^{-}$in wet plus dry deposition. The nearest meteorological network with longterm data for $\mathrm{Cl}^{-}$concentrations in wet plus dry deposition is the U.S. Environmental Protection Agency (USEPA) Clean Air Status and Trends Network (CASTNET), which includes two stations that geographically bracket the study sites: site SAN189 is approximately $200 \mathrm{~km}$ north in Knox County, Nebr. (not shown); and site KNZ184 is $220 \mathrm{~km}$ south in Riley, Kansas, at the Konza Prairie (not shown). The mean annual $q_{C l-}( \pm 1$ standard deviation) was $0.081 \pm 0.029$ grams per square meter $\left(\mathrm{g} / \mathrm{m}^{2}\right)$ between 2004 and 2011 at the CASTNET sites SAN189 and KNZ184. The lack of site-specific $q_{C l-}$ represents a large source of uncertainty in the water-flux estimates using the $\mathrm{Cl}^{-}$profiles. Because the use of equation 2 requires the assumption that $\mathrm{Cl}^{-}$flux at the land surface was constant with time, variability in $c_{C l-}$ is attributed to variations in the water flux. Water fluxes calculated for depths below the root zone ( $>2 \mathrm{~m}$ bls) for sites 1,4 , and 8 averaged $21,4.3$, and $13 \mathrm{~mm} / \mathrm{yr}$, respectively. The greater water flux in the eastern part of the study area (site 1) is consistent with greater mean annual precipitation than in the western part of the study area (site 8) and possibly the greater percentage of sand in the UZ beneath site 1 than site 8 . The smaller mean water flux beneath site $4(4.3 \mathrm{~mm} / \mathrm{yr})$ may be attributed to greater percentages of clay and silt in the UZ compared to sites 1 and 8.

\section{Nitrate Profiles}

The $\mathrm{NO}_{3}^{-}$profiles contain additional information about water movement in the UZ beneath each site and are shown in figures 11-18. In general, the $\mathrm{NO}_{3}{ }^{-}$concentrations in $\mathrm{UZ}$ pore water were larger beneath the irrigated and dryland agricultural sites as compared with the rangeland sites. The range of maximum and mean $\mathrm{NO}_{3}{ }^{-}$concentrations in pore water beneath the five agricultural sites are 1.42 to $37.56 \mu \mathrm{g} / \mathrm{g}$ and 1.33 to $22.08 \mu \mathrm{g} / \mathrm{g}$, respectively, which generally is larger than the range of the maximum and mean $\mathrm{NO}_{3}$-concentrations in pore water beneath the rangeland sites ( 1.33 to $6.52 \mu \mathrm{g} / \mathrm{g}$ and 0.37 to $1.57 \mu \mathrm{g} / \mathrm{g}$, respectively) (table 5). This pattern is consistent with the overlying land-use differences and application of nitrogen fertilizer at the agricultural sites that also are present at other sites in the High Plains aquifer (Gurdak and Qi, 2006; Gurdak and others, 2008; McMahon and others, 2006). The use of $\mathrm{NO}_{3}{ }^{-}$profiles together with the ${ }^{3} \mathrm{H}$ and $\mathrm{Cl}^{-}$profiles provides a more complete understanding of the effects of land use and precipitation on water movement in the UZ.

At the rangeland sites 1, 4, and 8 , the general shape of $\mathrm{NO}_{3}^{-}$and $\mathrm{Cl}^{-}$profiles, including the depths of peak concentrations, beneath each site are generally similar (figs. 11, 14, and 18). For example, at site 1 (fig. 11), reasonably larger concentrations of $\mathrm{NO}_{3}^{-}$and $\mathrm{Cl}^{-}$are present from $0-1 \mathrm{~m} \mathrm{bls}$, $4 \mathrm{~m}$ bls, and from about 15-20 m bls. At site 1, the concentrations of $\mathrm{NO}_{3}^{-}$and $\mathrm{Cl}^{-}$are smaller and less variable with depth than those at the other rangeland or agricultural sites (fig. 11). The $\mathrm{NO}_{3}{ }^{-}$and $\mathrm{Cl}^{-}$profiles at site 1 are consistent with a predominantly downward $\psi_{T}$ gradient and consequently have considerably smaller concentrations than the large reservoirs

Table 5. Summary statistics for nitrate concentrations (in micrograms per gram as N) in soil pore water from soil samples collected beneath sites $1-8$.

\begin{tabular}{|c|c|c|c|c|c|c|c|c|}
\hline & Site 1 & Site 2 & Site 3 & Site 4 & Site 5 & Site 6 & Site 7 & Site 8 \\
\hline & Rangeland & $\begin{array}{l}\text { Irrigated } \\
\text { agriculture }\end{array}$ & $\begin{array}{l}\text { Dryland } \\
\text { agriculture }\end{array}$ & Rangeland & $\begin{array}{l}\text { Irrigated } \\
\text { agriculture }\end{array}$ & $\begin{array}{l}\text { Irrigated } \\
\text { agriculture }\end{array}$ & $\begin{array}{l}\text { Irrigated } \\
\text { agriculture }\end{array}$ & Rangeland \\
\hline Minimum & 0.05 & 0.06 & 0.06 & 1.24 & 1.23 & 0.17 & 6.59 & 0.09 \\
\hline Mean & 0.37 & 2.12 & 3.85 & 1.57 & 1.33 & 7.44 & 22.08 & 1.55 \\
\hline Maximum & 1.33 & 13.04 & 26.16 & 3.52 & 1.42 & 22.55 & 37.56 & 6.52 \\
\hline Number of samples & 30 & 74 & 51 & 22 & 9 & 30 & 2 & 29 \\
\hline
\end{tabular}


of $\mathrm{NO}_{3}{ }^{-}$and $\mathrm{Cl}^{-}$that are located immediately below the root zone in more arid rangeland regions of the High Plains aquifer because of the predominant upward $\psi_{T}$ gradient in the near surface (McMahon and others, 2003, 2006; Gurdak and others, 2007). The reasonably smaller concentrations and lack of large peaks in concentrations in the $\mathrm{NO}_{3}^{-}$and $\mathrm{Cl}^{-}$profiles at site 1 may also indicate a reasonably larger and more consistent water flux in the UZ than beneath the other two rangeland sites, which is consistent with the ${ }^{3} \mathrm{H}$ profile that indicates flushing of post-bomb ${ }^{3} \mathrm{H}$ beneath site 1 .

The $\mathrm{NO}_{3}^{-}$and $\mathrm{Cl}^{-}$profiles beneath rangeland sites 4 and 8 each have at least one considerable peak in concentration (figs. 14 and 18). The peak concentrations in $\mathrm{NO}_{3}^{-}$and $\mathrm{Cl}^{-}$are present at similar depths at each site (about $16 \mathrm{~m}$ and $19 \mathrm{~m}$ bls beneath site 4 and about 7-8 $\mathrm{m}$ bls beneath site 8 ), which indicates a similar source and time since mobilization. The $\mathrm{NO}_{3}^{-}$and $\mathrm{Cl}^{-}$pore-water reservoirs beneath rangeland sites 4 and 8 are orders of magnitude smaller than similar reservoirs beneath rangeland sites in the more arid central and southern High Plains aquifer and beneath agricultural sites from this study. The similarity in $\mathrm{NO}_{3}{ }^{-}$and $\mathrm{Cl}^{-}$profiles beneath sites 4 and 8 further indicates incompletely flushed $\mathrm{NO}_{3}^{-}$and $\mathrm{Cl}^{-}$ that accumulated in pore water from natural processes during reasonably drier periods at these rangeland sites. The lack of pre-bomb ${ }^{3} \mathrm{H}$ in the profile beneath site 4 indicates that the $\mathrm{NO}_{3}{ }^{-}$and $\mathrm{Cl}^{-}$accumulated during a drier period sometime since the 1960s. At site 8 the pre-bomb/post-bomb interface in the ${ }^{3} \mathrm{H}$ profile was at $14 \mathrm{~m}$ bls, which was deeper than the peak concentrations in $\mathrm{NO}_{3}^{-}$and $\mathrm{Cl}^{-}$and indicates that the $\mathrm{NO}_{3}{ }^{-}$and $\mathrm{Cl}^{-}$accumulated during a drier period sometime since the 1950 s or 1960s and has not yet flushed through to the water table.

The depths of reasonably high and low concentrations in the $\mathrm{NO}_{3}^{-}$and $\mathrm{Cl}^{-}$profiles is generally similar among the agricultural sites (sites 2, 3, and 5-7), with some notable exceptions (figs. 12, 13, and 15-17). At site 2, the peak $\mathrm{NO}_{3}^{-}$concentration is at approximately $12 \mathrm{~m}$ bls and the $\mathrm{NO}_{3}^{-}$profile has reasonably large concentration from $12-15 \mathrm{~m}$ bls, which does not correspond to a distinct peak in $\mathrm{Cl}^{-}$concentration (fig. 12); however, the $\mathrm{Cl}^{-}$concentrations in the profile above $12-15 \mathrm{~m}$ bls are generally greater than those concentrations below $12-15 \mathrm{~m}$ bls and likely reflect application of irrigation water that has a larger concentration of $\mathrm{Cl}^{-}$than precipitation before the onset of irrigated agriculture. The peak $\mathrm{NO}_{3}{ }^{-}$concentration also is consistent with the ${ }^{3} \mathrm{H}$ bomb peak at approximately $10 \mathrm{~m}$ bls. The $\mathrm{NO}_{3}^{-}, \mathrm{Cl}^{-}$, and ${ }^{3} \mathrm{H}$ profiles indicate that water that infiltrated since the 1950s and 1960s is still present in the UZ at depths ranging from land surface to approximately $12-15 \mathrm{~m}$ bls. Below $15 \mathrm{~m}$ bls, the concentrations of the chemical profiles are similar to the natural rangeland sites and may reflect the land-use history before the conversion to agricultural land.

The shape of $\mathrm{NO}_{3}^{-}$and $\mathrm{Cl}^{-}$profiles beneath site 3 (dryland) had similar depth to the peak concentration (fig. 13), but were different than the $\mathrm{NO}_{3}^{-}$and $\mathrm{Cl}^{-}$profiles beneath the irrigated agricultural site 2 . At site 3 , the peak $\mathrm{NO}_{3}{ }^{-}$and
$\mathrm{Cl}^{-}$concentrations are at approximately $8-10 \mathrm{~m}$ bls, with larger concentrations of $\mathrm{NO}_{3}^{-}$and $\mathrm{Cl}^{-}$than those typifying rangeland that extend to nearly $20 \mathrm{~m}$ bls and cross the prebomb/post-bomb ${ }^{3} \mathrm{H}$ interface at $15 \mathrm{~m}$ bls (fig. 13). Below $20 \mathrm{~m}$ bls, $\mathrm{NO}_{3}^{-}$and $\mathrm{Cl}^{-}$concentrations are substantially smaller, which is similar to the concentrations beneath the natural rangeland sites and may reflect land-use history before the conversion to dryland agriculture. The similar shape of the $\mathrm{NO}_{3}^{-}$and $\mathrm{Cl}^{-}$profiles beneath site 3 are additional evidence that the large peaks in $\mathrm{NO}_{3}^{-}$and $\mathrm{Cl}^{-}$concentrations were the result of natural accumulation before the conversion of rangeland to a dryland agricultural site. Beneath site 3 , the $\mathrm{Cl}^{-}$concentrations in the profile above $8 \mathrm{~m}$ bls are 0.3 to $0.9 \mu \mathrm{g} \mathrm{g}^{-1}$, which is approximately one order of magnitude smaller than concentrations (3-6 $\mu \mathrm{g} / \mathrm{g})$ at similar depths beneath site 2 . The difference in $\mathrm{Cl}^{-}$concentrations between the two sites is attributed to larger $\mathrm{Cl}^{-}$concentrations in groundwater used for irrigation at site 2 than the $\mathrm{Cl}^{-}$concentrations in precipitation at site 3 .

The $\mathrm{NO}_{3}^{-}$profile beneath the irrigated corn site 5 stood out because the pattern of concentrations in the uppermost $8 \mathrm{~m}$ was related inversely to peak concentrations of $\mathrm{Cl}^{-}$(fig. 15). The source of the $\mathrm{NO}_{3}^{-}$in the profile cannot be distinguished on the basis of data presented in this report. The inverse relation between the $\mathrm{NO}_{3}{ }^{-}$and $\mathrm{Cl}^{-}$profile may be attributed either to different sources of water and chemicals that contributed to the peak $\mathrm{NO}_{3}{ }^{-}$and $\mathrm{Cl}^{-}$concentrations or to $\mathrm{NO}_{3}{ }^{-}$removal by denitrification possibly during the growing season or a flooding event that contributed the large $\mathrm{Cl}^{-}$concentrations, or both. The ${ }^{3} \mathrm{H}$ profile indicates that the $\mathrm{NO}_{3}^{-}$and $\mathrm{Cl}^{-}$concentrations are the result of recent land-use activities during the recent decades.

The $\mathrm{NO}_{3}^{-}$and $\mathrm{Cl}^{-}$profiles beneath irrigated agricultural site 6 were somewhat similar in shape, indicating a similar agricultural source that has been mobilized to similar depths in the UZ profile (fig. 16). Results from tritium samples from site 6 indicate that the larger concentrations of $\mathrm{NO}_{3}{ }^{-}$and $\mathrm{Cl}^{-}$in the UZ profile from the bottom of the root zone to the water table accumulated during the post-bomb era. The $\mathrm{NO}_{3}^{-}$profile beneath site 7 (irrigated) is not discussed herein, because the UZ thickness was approximately $1 \mathrm{~m}$ in 2010, when most UZ samples were collected for geochemical determinations.

\section{Bromide Profiles}

Profiles from the $2012 \mathrm{Br}^{-}$data were created for all eight sites (figs. 11-18). Sites 1 and 2 (figs. 11 and 12) provided the best information regarding overall recharge rates, because there was a 2.8-year interval between application and collection. At these two sites the $\mathrm{Br}^{-}$pulse had moved noticeably into the system (site 2; fig. 12), or beneath the root zone (site 1; fig. 11).

Heterogeneity of soils controls water movement at all spatial scales (Tang and others, 2010). Water movement through soils is dependent on the size and interconnectivity 
of the soil pores. Movement of water through macropores can be much faster than that of the surrounding representative soil matrix (Beven and Germann, 1982; Nimmo, 2007). Morphologically, macropores generally are formed by (1) soil fauna, which generally are concentrated closer to the land surface; (2) plant roots, which may decrease appreciably with depth, (3) cracks, soil structure, and fissures; and (4) natural soil pipes such as pores formed by erosive action of subsurface flow (Beven and Germann, 1982).

For flow to occur along a macropore, saturation of the whole soil matrix is not necessary; however, saturation must start the process (Mosley, 1982). Nimmo (2007) reported that the maximum speed of preferential flow (macropore, fingered, or funneled) in the UZ seems to vary less with location and medium of the subsurface material than do typical subsurface transport rates. Adjusted for episodicity of infiltration, Nimmo (2007) reported a quantitative predictive model that deviates little from the geometric mean of 13 meters per day $(\mathrm{m} / \mathrm{d})$ for one-dimensional vertical preferential continuous-input flow in the UZ.

Infiltration of the $\mathrm{Br}^{-}$generally did not exceed the root zone at sites 3-8 because of the short temporal interval between application (June 2011) and collection (April 2012). Consequently, the results of the analyses likely do not represent mean recharge values in the UZ at these sites. The $\mathrm{Br}^{-}$profiles at sites 3-6 and 8 indicate the $\mathrm{Br}^{-}$remained in the upper $0.3 \mathrm{~m}$ and in the upper $0.7 \mathrm{~m}$ at site 7 . Recharge values for these six sites range from $35 \mathrm{~mm} / \mathrm{yr}$ at site 8 to $256 \mathrm{~mm} / \mathrm{yr}$ at site 7 (center of mass) and $9 \mathrm{~mm} / \mathrm{yr}$ at site 1 to $394 \mathrm{~mm} / \mathrm{yr}$ at site 7 (peak displacement). Comparing methods of recharge among sites 3-6 and 8, the recharge rates were all within the same order of magnitude and were concordant at sites 5 and 6 , 58 and $65 \mathrm{~mm} / \mathrm{yr}$, respectively (table 4). As the $\mathrm{Br}^{-}$from the $\mathrm{KBr}$ tracer tests continues to move beneath the root zone and deeper into the UZ at sites 3-6 and 8, the applied tracer may be a more useful indicator of recharge rates at these sites, just as it seemed to be at sites 1 and 2 .

Substantial differences were noted between results from the center of mass and peak displacement methods. At site 8 , a recharge rate of $35 \mathrm{~mm} / \mathrm{yr}$ was calculated using the center-ofmass method, but $201 \mathrm{~mm} / \mathrm{yr}$ was calculated using the peakdisplacement method. Although method-related discrepancies between recharge rates exist at the same site, it seems that results from the center of mass (eq. 7) compare more favorably with results of other methods such as $\mathrm{Cl}^{-}$mass balance and ${ }^{3} \mathrm{H}$ profile (table 4). Results from equation 7 generally are within the same order of magnitude as those from the $\mathrm{Cl}^{-}$mass balance and ${ }^{3} \mathrm{H}$ profile tests.

The $\mathrm{Br}^{-}$profiles at site 1 (rangeland) and site 2 (irrigated) indicate the difference between a rangeland and an irrigated site (figs. 11 and 12; table 4). The concentration of $\mathrm{Br}^{-}$in the profile at site 1 (rangeland) (fig. 11) was largest in the uppermost 1 meter of the UZ, did not exceed $5 \mu \mathrm{g} / \mathrm{g}$, and averaged about $0.97 \mu \mathrm{g} / \mathrm{g}$ from 1 to $2 \mathrm{~m}$ bls. The $\mathrm{Br}^{-}$penetration depth $\left(Z_{T}\right)$ for site 1 was approximately $1.26 \mathrm{~m}$ bls. This depth was about $1 \mathrm{~m}$ deeper than sites 3-6 and 8, and about $0.5 \mathrm{~m}$ deeper than site 7 . Concentrations were largest in the upper $0.5 \mathrm{~m}$ then lessened with several peaks at about $0.8 \mathrm{~m}, 1.6 \mathrm{~m}$, and a smaller peak at $2.5 \mathrm{~m}$ bls. These peaks below $0.5 \mathrm{~m}$ likely are resulting from (1) a combination of $\mathrm{Br}^{-}$migrating with local precipitation events from 2009 to 2012 that infiltrated the upper part of the UZ, and (2) some macro-pore assemblage present in the soil that caused uneven infiltration of soil water and the resultant peaks in the $\mathrm{Br}$ concentrations below the primary peak concentrations. Overall, a recharge rate determined using the peak-displacement method indicates a recharge of about $9 \mathrm{~mm} / \mathrm{yr}$; whereas the center of mass indicates a recharge rate of about $38 \mathrm{~mm} / \mathrm{yr}$, or 4 times as much. The recharge rate as determined by the center of mass $(38 \mathrm{~mm} / \mathrm{yr})$ is in better agreement with the $\mathrm{Cl}^{-}$ and ${ }^{3} \mathrm{H}$ profile methods determined for this site (table 4) and discussed above.

Conversely, site 2 (irrigated) (fig. 12; table 4) indicates a $\mathrm{Br}^{-}$profile that seems more intact and symmetrical than that for site 1 (rangeland). In addition, the peak concentration $(12.7 \mu \mathrm{g} / \mathrm{g})$ was twice the magnitude of peak $\mathrm{Br}^{-}$concentration at site 1 . The $\mathrm{Br}^{-}$profile for site 2 indicates a $Z_{T}$ that was the deepest of the eight sites, with center of mass at $1.7 \mathrm{~m} \mathrm{bls}$ and a peak concentration at approximately $1.9 \mathrm{~m}$ bls. A recharge rate as determined from the peak displacement method indicates a recharge of about $172 \mathrm{~mm} / \mathrm{yr}$. The center of tracer mass at site 2 indicates a recharge rate of about $207 \mathrm{~mm} / \mathrm{yr}$. Both of these site 2 recharge rates are within the same order of magnitude but substantially greater than the recharge rates estimated for site 1 ( 9 and $38 \mathrm{~mm} / \mathrm{yr}$ for peakdisplacement and center-of-mass methods, respectively). This suggests recharge beneath irrigated fields, such as at site 2, can be substantially greater than recharge beneath rangeland sites, such as site 1 .

In general, the movement of $\mathrm{Br}^{-}$in pore water from the applied $\mathrm{KBr}$ tracer indicates greater water fluxes in the $\mathrm{UZ}$ beneath the agricultural sites ( 58 to $394 \mathrm{~mm} / \mathrm{yr}$ ) than the rangeland sites ( 9 to $201 \mathrm{~mm} / \mathrm{yr}$ ). The water flux estimates from the $\mathrm{Br}^{-}$movement generally are much larger than from other UZ methods.

\section{Groundwater Quality and Age}

Groundwater quality was used to determine the end members of the UZ chemistry, and groundwater age was used to determine groundwater residence time and to estimate recharge rates. "An end member is defined as water having a characteristic geochemical signature that best represents a source of groundwater inflow to the system" (Long and others, 2012, p. 11). Groundwater quality sampling was used to quantify concentrations of chemical constituents in shallow groundwater for comparison with chemical concentrations in the UZ. Apparent groundwater age determination was used to quantify groundwater mixing and residence times for shallow groundwater in the study area. Water flux through the $\mathrm{UZ}$ largely was determined by analysis of ${ }^{3} \mathrm{H}^{\text {and }} \mathrm{Cl}^{-}$profiles. 
Groundwater age was investigated through analysis of atmospheric environmental tracers. For this study CFCs, $\mathrm{SF}_{6}$, ${ }^{3} \mathrm{H},{ }^{3} \mathrm{H} /{ }^{3} \mathrm{He}$, and dissolved gases were measured to determine groundwater residence times and vertical groundwater fluxes. The concentrations of environmental tracers detected in groundwater samples analyzed during this study are listed in appendix table 1-2.

Age of groundwater samples in the study area ranged from "old" (recharged more than 50 years ago) to groundwater that has recharged less than 10 years ago (for this study 2000 and herein after called "modern") (appendix table 1-2). Groundwater samples from the deepest monitoring wells (such as at sites 1-4) generally had the longest residence time, and groundwater samples from the shallowest monitoring wells (such as at sites 5-8) had the shortest residence time. Vertically (groundwater age range between the shallowest and deepest monitoring wells within a site), groundwater age ranged from 20 or 30 years at sites located in the upland (sites $1-4,8$ ) to less than 5 years at sites located in the Platte River valley (sites 5-7).

Delin and others (2007) report use of groundwater-age dating and well-depth information to determine groundwater vertical velocities at the water table $V_{v}^{o}$. Specifically, an assumption of exponential age distribution of the aquifer allowed for the determination of $V_{v}^{o}$, in millimeters per year, using the following equation (Vogel, 1967; Delin and others, 2000):

$$
V_{v}^{o}=(\mathrm{Z} / \operatorname{age}(i)) * \ln \{\mathrm{Z} /[\mathrm{Z}-\mathrm{Z}(i)]\}
$$

where

$Z \quad$ is the nominal thickness of the saturated zone
(in millimeters),
age $(i) \quad$ is the age of the groundwater sample (in years
before the sample date), and
$z(i) \quad$ is the depth of the water parcel below the
$\quad$ water table (in millimeters).

Groundwater recharge rates (in millimeters per year) were calculated by multiplying the mean saturated-zone porosity $(\varphi)$ by $V_{v}^{o}$ using equation 9 :

$$
\text { Recharge }=\varphi V_{v}^{o}
$$

Groundwater recharge rates also were calculated using a linear groundwater-age vertical profile as determined using equation 10:

$$
V_{v}^{o}=z_{s} \text { lage }
$$

where

$$
z_{s} \quad \text { is the depth of the middle of the well screen }
$$$$
\text { (millimeters), and }
$$

age is the age of the groundwater sample (in years before the sample date) (Delin and others, 2007).

Likewise, $V_{v}^{o}$ computed with equation 10 was converted to recharge rate using equation 9 .
For this study, groundwater recharge values were computed for an aquifer in two ways - with exponential age distribution and with linear age distribution. During installation of the monitoring wells, the test holes did not penetrate the whole aquifer. Therefore, aquifer properties of thickness $(Z)$ and $\varphi$ were expressed as nominal values based on nearby test holes and drillers logs. Equations 8 and 9 were used to determine recharge for an aquifer with exponential age distribution, whereas equations 9 and 10 were used to determine recharge for an aquifer with linearly distributed groundwater age.

Age dates from each monitoring well were determined for exponential- or linear (piston)-age distributions using equations 8 and 10. Idealized exponential groundwater-age distribution occurs when uniform recharge occurs over an aquifer (Jurgens and others, 2012) and age distribution lines converge exponentially from the water table to the base of the aquifer (Maloszewski and Zuber, 1982; Jurgens and others, 2012). Conversely, idealized linear, or piston, groundwaterage distribution occurs when an unconfined aquifer receives uniform areal recharge and short-screened wells are located in the shallow part of the aquifer (Maloszewski and Zuber, 1982; Jurgens and others, 2012). Age-distribution line separation for linearly distributed ages, or piston-flow aquifers, is constant throughout, and no mixing or dispersion occurs. The shallowest wells at each site would be good candidates for linear, or piston-flow, age distribution, because the shallowest monitoring wells were placed near the shallow seasonal water table at each site. Because of the proximity of the shallow monitoring wells to the water table, groundwater ages from the shallowest monitoring wells were used to determine recharge rates at the water table. Groundwater ages from the deeper wells likely represented recharge rates from distant locations or regional flow systems.

Groundwater velocity values for the shallowest monitoring wells generally were concordant for equations 8 and 10; consequently, the largest difference in recharge was about 9 percent at site 1 (site 1-26, $25 \mathrm{~mm} / \mathrm{yr}$ to $23 \mathrm{~mm} / \mathrm{yr}$ for the exponential and linear models, respectively). The two largest differences in recharge (comparing exponential with linear age distribution) were at deeper monitoring wells - 27 and 32 percent (sites 7-14 and 1-35, respectively). Moreover, the smallest difference in recharge (again comparing exponential with linear) at deeper monitoring wells was about 8 percent at site 6 (site 6-27). Exponential and linear models seem to have worked better for data collected from shallower monitoring wells; at each site the concordance was closest in the shallowest monitoring wells and most distant for deep wells.

Analysis of recharge rates determined from the environmental-tracers data with other methods used during this study indicated mixed results. Recharge rates determined from $\mathrm{Cl}^{-}$mass balance, ${ }^{3} \mathrm{H}$ profile, and $\mathrm{Br}^{-}$profile centerof-mass and peak-displacement methods were completed at selected sites and were comparable to rates determined by groundwater-age dating methods from those respective sites (table 4). For instance, overall, the range of recharge values calculated from various methods for site 1 was the smallest 
of any site. At site 1-26, recharge rates determined from the age-dating results $(24 \mathrm{~mm} / \mathrm{yr})$ were comparable to those determined from the mean $\mathrm{Cl}^{-}$mass balance $(21 \mathrm{~mm} / \mathrm{yr})$ and the mean $\mathrm{Br}^{-}$profile method $(24 \mathrm{~mm} / \mathrm{yr})$, but not from the ${ }^{3} \mathrm{H}$ profile method ( $>53 \mathrm{~mm} / \mathrm{yr}$ ). Conversely, age-dating results from the deeper wells (site 1-30 with a mean recharge rate of $56 \mathrm{~mm} / \mathrm{yr}$, and site 1-35 with a mean recharge rate of $65 \mathrm{~mm} / \mathrm{yr}$ ) were similar to those determined from the ${ }^{3} \mathrm{H}$ profile, but not comparable to the mean $\mathrm{Cl}^{-}$mass balance or the mean $\mathrm{Br}^{-}$method (table 4). At site 4, the age-dating method only was completed for the shallowest monitoring well (site 4-29; table 4). At site 4-29, the resultant recharge rate $(14 \mathrm{~mm} / \mathrm{yr})$ was barely more than 3 times greater than the mean $\mathrm{Cl}^{-}$mass-balance method $(4.3 \mathrm{~mm} / \mathrm{yr})$, well under the ${ }^{3} \mathrm{H}$-based rate $(>80 \mathrm{~mm} / \mathrm{yr})$, and an order of magnitude less than the mean $\mathrm{Br}^{-}$method (139 mm/yr) (table 4). Therefore, these methods indicated recharge rates that differed by orders of magnitude. Site 8 was the only site to have all seven methods of recharge computed $-\mathrm{Cl}^{-}$mass balance, ${ }^{3} \mathrm{H}$ profile center of mass and peak displacement, $\mathrm{Br}^{-}$profile center of mass and peak displacement, and age dating linear and exponential methods (table 4). Although the two ${ }^{3} \mathrm{H}$-based recharge rates $(53 \mathrm{~mm} / \mathrm{yr}$ for peak-displacement method and $10 \mathrm{~mm} / \mathrm{yr}$ for center-of-mass method) bracketed the mean age-dating rate $(34 \mathrm{~mm} / \mathrm{yr}$ ) in the shallow monitoring well (site 8-18), the mean age-dating resultant was not comparable to the mean $\mathrm{Br}^{-}$-based result $(118 \mathrm{~mm} / \mathrm{yr})$ and marginally comparable to the mean $\mathrm{Cl}^{-}$-based result $(13 \mathrm{~mm} / \mathrm{yr})$. At site 8 , the age-dating results from the deeper well $(8-24 ; 113 \mathrm{~mm} / \mathrm{yr})$ was similar to the mean $\mathrm{Br}^{-}$-based result, but not comparable to the ${ }^{3} \mathrm{H}$ or the mean $\mathrm{Cl}^{-}$-based results. Importantly, the $\mathrm{KBr}$ tests at sites $3-8$ only lasted about 244 days. Consequently, the recharge rate from the $\mathrm{Br}^{-}$-profile method likely did not accurately represent recharge rates through the entire soil profile.

Sites 5-7 had results from age-dating linear and exponential methods, and $\mathrm{Br}^{-}$profile center-of-mass and peakdisplacement methods (table 4). Sites 5 and 6 also had results from ${ }^{3} \mathrm{H}$ profile peak-displacement method of analysis. The mean age-dating resultant $(34 \mathrm{~mm} / \mathrm{yr})$ at site 5-14 was similar to the ${ }^{3} \mathrm{H}$ profile peak-displacement method ( $>29 \mathrm{~mm} / \mathrm{yr}$ ), but the mean $\mathrm{Br}^{-}$profile resultant $(58 \mathrm{~mm} / \mathrm{yr})$ was nearly twice that of the other two methods. At sites 6 and 7, the mean agedating resultant and $\mathrm{Br}^{-}$-profile methods produced results that were different by about fourfold - recharge values from agedating methods were much larger at site 6 than the $\mathrm{Br}^{-}$-profile method and much lower than the $\mathrm{Br}^{-}$-profile method as site 7 (table 4). The ${ }^{3} \mathrm{H}$ profile peak-displacement resultant $(>48 \mathrm{~mm} /$ $\mathrm{yr})$ at site 6 was similar to the $\mathrm{Br}^{-}$resultant $(65 \mathrm{~mm} / \mathrm{yr})$, but not comparable to the mean age-dating resultant $(224 \mathrm{~mm} / \mathrm{yr}$ ).

In general, at many sites, the recharge rates from the groundwater-age dating method at the shallowest monitoring well were similar to recharge rates from the ${ }^{3} \mathrm{H}$ and $\mathrm{Cl}^{-}$massbalance methods. Per site, the groundwater recharge rates generally increased with well depth. The groundwater-agebased recharge rates from deeper monitoring wells may not represent local recharge conditions because the contributing area of these wells is much larger than the shallowest monitoring wells.

The data from the UZ and saturated zone generally demonstrate that the spatial patterns of water movement in the UZ and recharge rates primarily are affected by spatial contrasts in mean annual precipitation and land use/land cover. The eight UZ sites generated unique and valuable data that are likely to help improve groundwater management in the CPNRD. Continued monitoring of these sites will help to address questions of temporal patterns in water movement in the UZ and recharge rates.

\section{Summary and Conclusions}

Understanding the effects of land use and climate on water movement in the UZ and on recharge rates is critically important to develop appropriate management and sustainability plans for groundwater resources in the Central Platte Natural Resources District (CPNRD) study area and other parts of the High Plains aquifer. In particular, field-based estimates of recharge rates under selected land-use types and along the east-west precipitation gradients in the CPNRD study area can be used to better calibrate and validate the Cooperative Hydrology Study (COHYST) groundwater model, which is an important tool used to help maintain critical flows as outlined in the Cooperative Agreement partnership. This report describes the results of a study to determine water movement through the unsaturated zone (UZ) and recharge rates to parts of the northern High Plains aquifer within the CPNRD study area. Chemical, hydraulic, and physical data were collected from throughout the UZ and within the saturated zone to quantify water movement in the UZ and recharge rates at four sites where irrigated agriculture was the dominant land use, one site where nonirrigated (dryland) agriculture was the dominant land use, and three sites where rangeland was the dominant land use. The eight sites provide an east-west contrast in precipitation conditions within the CPNRD.

Transient vertical gradients in total water potentials in the UZ indicated that periodic wetting fronts generally reached greater mean maximum depths beneath the irrigated agricultural sites than the corresponding rangeland sites. The greater maximum depth of wetting fronts beneath the irrigated agricultural sites are attributed to greater and more constant antecedent moisture and total potential $\left(\psi_{T}\right)$ conditions that are controlled in part by the irrigation practices. The smaller maximum depth of wetting fronts beneath the rangeland sites was attributed to smaller and more variable antecedent moisture and $\psi_{T}$ conditions that were a function of local precipitation and evapotranspiration by natural vegetation. In addition to greater variability in the $\psi_{T}$ profiles beneath rangeland sites than corresponding irrigated sites, there also was greater variability in the $\psi_{T}$ profiles beneath the western sites than the corresponding eastern sites, which was attributed to less mean annual precipitation in the western part of the study area and 
greater mean annual precipitation in the eastern part of the study area. Although the $\psi_{T}$ profiles beneath rangeland and western sites have greater temporal variability in the upper 1-2 meters ( $\mathrm{m}$ ) below land surface (bls), the $\psi_{T}$ profiles greater than $2 \mathrm{~m}$ bls at many sites generally indicate a decrease in $\psi_{T}$ with depth and $\psi_{T}$ profiles that approximate unit gradient, which indicates a constant downward flux of water driven by gravity.

The depth of the post-bomb peak or the interface between pre-bomb and post-bomb tritium $\left({ }^{3} \mathrm{H}\right)$ and a ${ }^{3} \mathrm{H}$ mass balance were used to estimate water fluxes in the UZ at each site where appropriate. Although quantitative estimates of recharge rates using the depth of the interface between prebomb and post-bomb ${ }^{3} \mathrm{H}$ and ${ }^{3} \mathrm{H}$ mass-balance methods could not be determined for sites $1,4,5$, and 6 because post-bomb ${ }^{3} \mathrm{H}$ had flushed through the entire profile, qualitative estimation of recharge rates at these sites concluded recharge to be modern (within 10 years of sampling). A minimum flux was estimated as greater than $(>) 53$ to $>80$ millimeters per year ( $\mathrm{mm} / \mathrm{yr}$ ) for the two rangeland sites (sites 1 and 4), respectively, and $>29$ to $>48 \mathrm{~mm} / \mathrm{yr}$ for the two irrigated agricultural sites (sites 5 and 6), respectively. At site 2 (irrigated), the discernible post-bomb ${ }^{3} \mathrm{H}$ peak was used to estimate a recharge rate of $68 \mathrm{~mm} / \mathrm{yr}$, and the assumed depth of the pre-bomb/post-bomb interface indicated a range of recharge rates from 133 to $159 \mathrm{~mm} / \mathrm{yr}$. The ${ }^{3} \mathrm{H}$ mass-balance method was used to estimate a recharge rate of $137 \mathrm{~mm} / \mathrm{yr}$. At site 3 (dryland), the interface between pre-bomb and post-bomb ${ }^{3} \mathrm{H}$ was used to estimate a recharge rate of $63 \mathrm{~mm} / \mathrm{yr}$, and the ${ }^{3} \mathrm{H}$ mass-balance method was used to estimate a recharge rate of $12 \mathrm{~mm} / \mathrm{yr}$. At site 8 (rangeland), the interface between prebomb and post-bomb ${ }^{3} \mathrm{H}$ was used to estimate a recharge rate of $53 \mathrm{~mm} / \mathrm{yr}$, and the ${ }^{3} \mathrm{H}$ mass-balance method was used to estimate a recharge rate of $10 \mathrm{~mm} / \mathrm{yr}$. Based on the mass-balance method, estimated recharge beneath the site 2 (irrigated) was 11 to 14 times larger than that beneath the nonirrigated (dryland) site 3 or rangeland site 8 , which indicates that irrigation affects water movement in the UZ and recharge rates. No ${ }^{3} \mathrm{H}$ data were collected at site 7 (irrigated) because at the time of sampling the UZ thickness was slightly greater than $1 \mathrm{~m}$, which was not adequately thick enough for ${ }^{3} \mathrm{H}$-based recharge-rate estimation methods.

Using the chloride $\left(\mathrm{Cl}^{-}\right)$mass-balance method, water fluxes calculated for depths below the root zone ( $>2 \mathrm{~m} \mathrm{bls}$ ) for rangeland sites 1, 4, and 8 ranged from 1.8 to $96 \mathrm{~mm} / \mathrm{yr}$, 1.1 to $9.6 \mathrm{~mm} / \mathrm{yr}$, and 1.1 to $68 \mathrm{~mm} / \mathrm{yr}$, with site means of 21 , 4.3 , and $13 \mathrm{~mm} / \mathrm{yr}$, respectively. The greater water flux in the eastern part of the study area (site 1) is consistent with greater mean annual precipitation than in the western part of the study area (site 8). The smaller mean water flux beneath site 4 $(4.3 \mathrm{~mm} / \mathrm{yr})$ may be attributed to greater percentage of clay and silt in the UZ compared to sites 1 and $8 . \mathrm{Cl}^{-}$mass balance water fluxes were not calculated at the irrigated or nonirrigated sites because water and $\mathrm{KCl}$ applications may have been additional sources of $\mathrm{Cl}^{-}$beyond atmospheric wet and dry deposition.
The nitrate $\left(\mathrm{NO}_{3}^{-}\right)$concentrations in $\mathrm{UZ}$ pore water are larger beneath the irrigated and nonirrigated (dryland) agricultural sites as compared with the rangeland sites, which is consistent with the application of nitrogen fertilizer at the agricultural sites and no substantial accumulation of $\mathrm{NO}_{3}{ }^{-}$in pore water from enrichment by evapotranspiration at the rangeland sites that is common at sites in more arid regions of the High Plains. At site 1 (rangeland), the shape of the $\mathrm{NO}_{3}^{-}$and $\mathrm{Cl}^{-}$profiles indicate a reasonably larger and more consistent water flux in the UZ than beneath the other two rangeland sites. The $\mathrm{NO}_{3}^{-}$ and $\mathrm{Cl}^{-}$profiles beneath rangeland sites 4 and 8 each have at least one considerable peak in concentrations that may indicate incompletely flushed $\mathrm{NO}_{3}^{-}$and $\mathrm{Cl}^{-}$that accumulated in pore water from natural processes during reasonably drier periods at these rangeland sites since the 1960s; however, the $\mathrm{NO}_{3}^{-}$and $\mathrm{Cl}^{-}$pore-water reservoirs beneath rangeland sites 4 and 8 are orders of magnitude smaller than similar reservoirs beneath rangeland sites in the more arid central and southern High Plains aquifer and beneath agricultural sites. Excluding site 7, the general shape of the $\mathrm{NO}_{3}{ }^{-}$profiles is similar beneath the agricultural sites and supports the estimates of water movement and recharge rates as determined from the ${ }^{3} \mathrm{H}_{\text {and }} \mathrm{Cl}^{-}$methods.

In general, the movement of bromide $\left(\mathrm{Br}^{-}\right)$in pore water from the applied potassium bromide $(\mathrm{KBr})$ tracer indicates greater water fluxes in the UZ beneath the agricultural sites (58 to $394 \mathrm{~mm} / \mathrm{yr}$ ) than the rangeland sites ( 9 to $201 \mathrm{~mm} / \mathrm{yr}$ ). The water flux estimates from the $\mathrm{Br}^{-}$movement generally are much larger than from other UZ methods; however, the water-flux estimates from the $\mathrm{KBr}$ tracer do not represent recharge rates at most sites (sites 3-8) because the $\mathrm{Br}^{-}$primarily was in the root zone at the time of sample collection. As the $\mathrm{Br}^{-}$from the $\mathrm{KBr}$ tracer continues to move beneath the root zone and deeper into the UZ, which it seemed to have done at sites 1 and 2, the applied tracer may be a more useful indicator of recharge rates.

The apparent groundwater age was used to determine groundwater residence time and to estimate recharge rates. Age of groundwater samples ranged from old (recharged more than 50 years ago) to modern (recharged less than 10 years ago). Groundwater samples from the deepest monitoring wells generally had longer residence times than groundwater samples from the shallowest monitoring wells. Because of the proximity of the shallow monitoring well to the water table, groundwater ages calculated from the shallowest monitoring wells were used to determine recharge rates at the water table. Recharge rates determined from groundwater ages calculated from the deeper wells likely represented rates from distant locations or regional flow systems.

At many sites, the recharge rates from the groundwaterage dating methods used at the shallowest monitoring wells were similar to recharge rates from the ${ }^{3} \mathrm{H}$ and $\mathrm{Cl}^{-}$mass-balance methods. Per site, the groundwater recharge rates generally increased with well depth. Moreover, the groundwater-age based recharge rates from deeper monitoring wells may not represent local recharge conditions because the contributing area of these wells is much larger than the shallowest monitoring wells. 
The data from the UZ and saturated zone generally demonstrate that the spatial patterns of water movement in the UZ and recharge rates primarily are affected by spatial contrasts in mean annual precipitation and land use/land cover. The eight UZ sites generated unique and valuable data that are likely to help improve groundwater management in the CPNRD. Continued monitoring of these sites will help to address questions of temporal patterns in water movement in the UZ and recharge rates.

\section{References Cited}

Allison, G.B., and Hughes, M.W., 1978, The use of environmental chloride and tritium to estimate total recharge to an unconfined aquifer: Australian Journal of Soil Research, v. 16 , no. 2, p. 181-195.

Allison, G.B., Gee, G.W., and Tyler, S.W., 1994, Vadose-zone techniques for estimating groundwater recharge in arid and semiarid regions: Soil Science Society of America Journal, v. 58 , p. $6-14$.

Beven, K., and Germann, P., 1982, Macropores and water flow in soils: Water Resources Research, v. 18, no. 5, p. 1,3111,325 .

Burt, R., ed., 2009, Soil survey field and laboratory methods manual: U.S. Department of Agriculture, Natural Resources Conservation Service, Soil Survey Investigations Report, no. 51, ver. 1.0, 407 p., accessed March 26, 2012, at http:// soils.usda.gov/technical/.

Busenberg, Eurybiades, and Plummer, L.N., 1992, Use of chlorofluorocarbons $\left(\mathrm{CCl}_{3} \mathrm{~F}\right.$ and $\left.\mathrm{CCl}_{2} \mathrm{~F}_{2}\right)$ as hydrologic tracers and age-dating tools-The alluvium and terrace system of central Oklahoma: Water Resources Research, v. 28, no. 9 , p. $2,257-2,283$.

Busenberg, Eurybiades, and Plummer, L.N., 2000, Dating young ground water with sulfur hexafluoride-Natural and anthropogenic sources of sulfur hexafluoride: Water Resources Research, v. 36, no. 10, p. 3,011-3,030.

Busenberg, Eurybiades, Plummer, L.N., Bartholomay, R.C., and Wayland, J.E., 1998, Chlorofluorocarbons, sulfur hexafluoride, and dissolved permanent gases in ground water from selected sites in and near the Idaho National Engineering and Environmental Laboratory, Idaho, 1994-97: U.S. Geological Survey Open-File Report 98-274, 72 p.

Carney, C.P., 2008, Groundwater flow model of the central model unit of the Nebraska Cooperative Hydrology Study (COHYST) area: Cooperative Hydrology Study Technical Committee, $87 \mathrm{p}$.
Center for Advanced Land Management Information Technologies, 2010, 2005 Land use mapping: Lincoln, University of Nebraska-Lincoln Center for Advanced Land Management Information Technologies (CALMIT), accessed January 18, 2011, at http://www.calmit.unl.edu/2005landuse.

Chen, X.-H., 1998, Assessment of hydraulic properties in an unconfined alluvial aquifer near Grand Island, Nebraska: Journal of the American Water Resources Association, v. 34, no. 3, p. 603-616.

Chen, X.-H., Goeke, J.W., Ayers, J.F., and Summerside, S.E., 2003, Observation well network design for pumping tests in unconfined aquifers: Journal of the American Water Resources Association, v. 39, no. 1, p. 17-32.

Clark, I.D., and Fritz, P., 1997, Environmental isotopes in hydrogeology: Boca Raton, Fla., Lewis Publishers, 328 p.

Cunningham, W.L., and Schalk, C.W., comps., 2011, Groundwater technical procedures of the U.S. Geological Survey: U.S. Geological Survey Techniques and Methods, book 1, chap. A1, $151 \mathrm{p}$.

Delin, G.N., Healy, R.W., Landon, M.K., and Böhlke, J.-K., 2000, Effects of topography and soil properties on recharge at two sites in an agricultural field: Journal of the American Water Resources Association, v. 36, no. 6, p. 1,401-1,416.

Delin, G.N., Healy, R.W., Lorenz, D.L., and Nimmo, J.R., 2007, Comparison of local- to regional-scale estimates of ground-water recharge in Minnesota, USA: Journal of Hydrology, v. 334, no. 1-2, p. 231-249.

Dreeszen, V.H., 1999, Hall County test-hole logs: University of Nebraska-Lincoln, Nebraska Water Survey Test-Hole Report No. 40, 125 p.

Dreeszen, V.H., Reed, E.C., and Burchett, R.R., Bedrock geologic map showing thickness of overlying Quaternary deposits, Grand Island quadrangle, Nebraska and Kansas: U.S. Geological Survey Miscellaneous Geologic Investigations Map I-819.

Fenneman, N.M., 1946, Physical divisions of the United States: U.S. Geological Survey map, scale 1:7,000,000.

Flint, A.L., Campbell, G.S., Ellett, K.M., and Calissendorff, C., 2002, Calibration and temperature correction of heat dissipation matric potential sensors: Soil Science Society of American Journal, v. 66, no. 5, p. 1,439-1,445.

Freeze, R.A., and Cherry, J.A., 1979, Groundwater: Englewood Cliffs, N.J., Prentice-Hall, 604 p.

Gee, G.W., and Hillel, D., 1988, Groundwater recharge in arid regions - Review and critique of estimation methods: Hydrological Processes, v. 2, no. 3, p. 255-266. 
Gurdak, J.J., and Qi, S.L., 2006. Vulnerability of recently recharged ground water in the High Plains regional aquifer to nitrate contamination: U.S. Geological Survey Scientific Investigations Report 2006-5050, 39 p.

Gurdak, J.J., Hanson, R.T., McMahon, P.B., Bruce, B.W., McCray, J.E., Thyne, G.D., and Reedy, R.C., 2007, Climate variability controls on unsaturated water and chemical movement, High Plains aquifer, USA: Vadose Zone Journal, v. 6 , no. 2 , p. $533-547$.

Gurdak, J.J., Walvoord, M.A., and McMahon, P.B., 2008. Susceptibility to enhanced chemical migration from depressionfocused preferential flow, High Plains aquifer: Vadose Zone Journal, v. 7, no. 4, p. 1,218-1,230, doi: 10.2136/ vzj2007.0145, accessed March 3, 2011. (Also available at https://www.soils.org/publications/vzj/abstracts/7/4/1172.)

Gurdak, J.J., McMahon, P.B., Dennehy, K.F., and Qi, S.L., 2009, Water quality in the High Plains Aquifer, Colorado, Kansas, Nebraska, New Mexico, Oklahoma, South Dakota, Texas, and Wyoming, 1999-2004: U.S. Geological Survey Circular 1337, $63 \mathrm{p}$.

Gutentag, E.D., Heimes, F.J., Krothe, N.C., Luckey, R.R., and Weeks, J.B., 1984, Geohydrology of the High Plains aquifer in parts of Colorado, Kansas, Nebraska, New Mexico, Oklahoma, South Dakota, Texas, and Wyoming: U.S. Geological Survey Professional Paper 1400-B, 63 p.

Hancock, T.C., Sandstrom, M.W., Vogel, J.R., Webb, R.M.T., Bayless, E.R., and Barbash, J.E., 2008, Pesticide fate and transport throughout unsaturated zones in five agricultural settings, USA: Journal of Environmental Quality, v. 37, no. 3, p. 1,086-1,100.

Healy, R.W., 2010, Estimating groundwater recharge: Cambridge, U.K., Cambridge University Press, 245 p.

Herbel, M.J., and Spalding, R.F., 1993, Vadose zone fertilizer derived nitrate and $\delta 15 \mathrm{~N}$ extracts: Ground Water, v. 31, p. $376-382$.

Irons, T.P., Hobza, C.M., Steele, G.V., Abraham, J.D., Cannia, J.C., and Woodward, D.D., 2012, Quantification of aquifer properties with surface nuclear magnetic resonance in the Platte River valley, central Nebraska, using a novel inversion method: U.S. Geological Survey Scientific Investigations Report 2012-5189, 50 p.

Izbicki, J.A., Radyk, J., and Michel, R.L., 2002, Movement of water through the thick unsaturated zone underlying Oro Grande and Sheep Creek Washes in the western Mojave Desert, USA: Hydrogeology Journal, v. 10, p. 409-427.

Johnston, C.D., 1987, Distribution of environmental chloride in relation to subsurface hydrology: Journal of Hydrology, v. 94, p. $67-88$.
Jurgens, B.C., Böhlke, J.-K., and Eberts, S.M., 2012, TracerLPM (Version 1)-An Excel ${ }^{\circledR}$ workbook for interpreting groundwater age distributions from environmental tracer data: U.S. Geological Survey Techniques and Methods Report, book 4, chap. F3, 60 p.

Kaufman, S., and Libby, W.F., 1954, The natural b-f distribution of tritium: Physical Review, v. 93, p. 1,337-1,344.

Lindau, C.W., and Spalding, R.F., 1984, Major procedural discrepancies in soil extracted nitrate levels and nitrogen isotopic values: Ground Water, v. 22, p. 273-278.

Long, A.J., Ohms, M.J., and McKaskey, J.D.R.G., 2012, Groundwater flow, quality (2007-10), and mixing in the Wind Cave National Park area, South Dakota: U.S. Geological Survey Scientific Investigations Report 2011-5235, $50 \mathrm{p}$.

Luckey, R.R., and Cannia, J.C., 2006, Groundwater flow model of the western model unit of the Nebraska Cooperative Hydrology Study (COHYST) area: Cooperative Hydrology Study Technical Committee, 63 p.

Ludin, A., Weppernig, R., BÖnisch, G., and Schlosser, Peter, 1998, Mass spectrometric measurement of helium isotopes and tritium in water samples: Palisades, New York, Lamont-Doherty Earth Observatory of Columbia University, Lamont-Doherty Earth Observatory Technical Report No. 98-6, 42 p. (Also available at $h t t p: / / w w w . l d e o . c o l u m-$ bia.edu/res/fac/etg.tmp/text/woce_tech.html.)

Maloszewski, P., and Zuber, A., 1982, Determining the turnover time of groundwater systems with the aid of environmental tracers-1. Models and their applicability: Journal of Hydrology, v. 57, no. 3-4, p. 207-231.

McGuire, V.L., Johnson, M.R., Schieffer, R.L., Stanton, J.S., Sebree, S.K., and Verstraeten, I.M., 2003, Water in storage and approaches to ground-water management, High Plains aquifer, 2000: U.S. Geological Survey Circular 1243, 51 p.

McGuire, V.L., and Kilpatrick, J.M., 1998, Hydrogeology in the vicinity of the Nebraska management systems evaluation area site, central Nebraska: U.S. Geological Survey Water-Resources Investigations Report 97-4266, 25 p.

McMahon, P.B., Dennehy, K.F., Michel, R.L., Sophocleous, M.A., Ellett, K.M., and Hurlbut, D.B., 2003, Water movement through thick unsaturated zones overlying the central High Plains aquifer, southwestern Kansas, 2000-2001: U.S. Geological Survey Water-Resources Investigations Report 03-4171, 35 p. 
McMahon, P.B., Dennehy, K.F., Bruce, B.W., Böhlke, J.-K., Michel, R.L., Gurdak, J.J., and Hurlbut, D.B., 2006, Storage and transit time of chemicals in thick unsaturated zones under rangeland and irrigated cropland, High Plains, United States: Water Resources Research, v. 42, W03413, doi:10.1029/2005WR004417.

McMahon, P.B., Dennehy, K.F., Bruce, B.W., Gurdak, J.J., and Qi, S.L., 2007, Water-quality assessment of the High Plains aquifer, 1999-2004: U.S. Geological Survey Professional Paper 1749, $212 \mathrm{p}$.

Michel, R.L., 2005, Tritium in the hydrologic cycle, in Aggarwal, P.K., Gat, J.R., and Froehlich, K.F.O., eds., Isotopes in the water cycle-Past, present and future: Amsterdam, Netherlands, International Atomic Energy Agency, p. 53-66.

Mosley, M.P., 1982, Subsurface flow velocities through selected forest soils, South Island, New Zealand: Journal of Hydrology, v. 55, no. 1-4, p. 65-92.

National Atlas, 2013, The Public Land Survey System (PLSS): National Atlas of the United States, unpaged, accessed February 6, 2013, at http://www.nationalatlas.gov/articles/ boundaries/a_plss.html\#one.

National Oceanic and Atmospheric Administration, 2013, Climate data online: National Climatic Data Center, accessed January 7, 2013, at http://www.ncdc.noaa.gov/cdoweb/\#t=secondTabLink.

Natural Resources Conservation Service, 1974, Buffalo County soil survey (SS-10): Washington, D.C., U.S. Department of Agriculture, $80 \mathrm{p}$., plus maps.

Natural Resources Conservation Service, 1978, Dawson County soil survey (SS-24): Washington, D.C., U.S. Department of Agriculture, 102 p., plus maps.

Natural Resources Conservation Service, 2004a, Hall County soil survey (SS-10): Washington, D.C., U.S. Department of Agriculture, 402 p., plus maps.

Natural Resources Conservation Service, 2004b, Soil survey laboratory methods manual: U.S. Department of Agriculture, Laboratory methods manual, v 4.0, 2004, accessed February 6, 2013, at https://prod.nrcs.usda.gov/wps/portal/ nrcs/detail/soils/research/?cid=nrcs142p2_054247.

Nimmo, J.R., 2007, Simple predictions of maximum transport rate in unsaturated soil and rock: Water Resources Research, v. 43, no. 5, W05426, doi: 10.1029/2006WR005372.

Nir, A., 1964, On the interpretation of tritium 'age' measurements of groundwater: Journal of Geophysical Research, v. 69 , no. 12 , p. $2,589-2,595$.
Peterson, S.M., 2007, Groundwater flow model of the eastern model unit of the Nebraska Cooperative Hydrology Study (COHYST) area: Cooperative Hydrology Study Technical Committee, $80 \mathrm{p}$.

Platte River Cooperative Hydrology Study, [1998], Introduction: Platte River Cooperative Hydrology Study (COHYST), accessed August 15, 2013, at http://cohyst.dnr. ne.gov/.

Rimon, Y., Dahan, O., Nativ, R., and Geyer, S., 2007, Water percolation through the deep vadose zone and groundwater recharge - Preliminary results based on a new vadose zone monitoring system: Water Resources Research, v. 43, W05402, doi:10.1029/2006WR004855.

Rimon, Y., Nativ, R., and Dahan, O., 2011, Physical and chemical evidence for pore-scale dual-domain flow in the vadose zone: Vadose Zone Journal, v. 10, p. 322-331, doi:10.2136/ vzj2009.0113.

Scanlon, B.R., 1991, Evaluation of moisture flux from chloride data in desert soils: Journal of Hydrology, v. 128, p. 137-156.

Scanlon, B.R., Healy, R.W., and Cook, P.G., 2002, Choosing appropriate techniques for quantifying groundwater recharge: Hydrogeology Journal, v. 10, no. 1, p. 18-39.

Soil Survey Division Staff, 1993, Soil survey manual: Soil Conservation Service, U.S. Department of Agriculture Handbook 18, [variously paged]. (Also available at $f t p: / /$ ftp-fc.sc.egov.usda.gov/NSSC/Soil_Survey_Manual/pdf/ SSM.pdf.)

Soil Survey Staff, 1999, Soil taxonomy-A basic system of soil classification for making and interpreting soil surveys ( $2 \mathrm{~d}$ ed.): Natural Resources Conservation Service, U.S. Department of Agriculture Handbook 436, 871 p. (Also available at http://soils.usda.gov/technical/ classification/taxonomy.)

Steele, G.V., 1994, Groundwater-levels in response to precipitation events, central Nebraska, 1987-1992: Lincoln, University of Nebraska-Lincoln, M.S. thesis, 183 p.

Tang, Xiang-Yu, Seuntjens, Piet, Cornelis, W.M., Boënne, Wesley, Verbist, Koen, and Van Hoey, Stijn, 2010, Evidence of subsurface flow through macropores in agricultural soils-Field investigations and modeling: Geophysical Research Abstracts, European Geosciences Union General Assembly 2010, Vienna, v. 12, p. 15,315.

Thatcher, L.L., 1962, The distribution of tritium fallout in precipitation over North America: International Association of Scientific Hydrology, Bulletin 7, no. 2, p. 48-58. 
Thatcher, L.L., Janzer, V.J., and Edwards, K.W., 1977, Methods for determination of radioactive substances in water and fluvial sediments: U.S. Geological Survey Techniques of Water-Resources Investigations, book 5, chap. A5, p. 79-81.

Tindall, J.A., and Kunkel, J.R., 1999, Unsaturated zone hydrology for scientists and engineers: Upper Saddle River, N.J., Prentice Hall, 624 p.

Todd, D.K., and Mays, L.W., 2005, Groundwater hydrology (3d ed.): Hoboken, N.J., John Wiley and Sons, 636 p.

U.S. Census Bureau, 2013, 2010, Demographic profile, total population: U.S. Census Bureau, American FactFinder, accessed August 29, 2013, at http://factfinder2.census.gov/ faces/nav/jsf/pages/index.xhtml.

U.S. Geological Survey, 2013a, Reston Stable Isotope Laboratory Isotope Fractionation Project, methods and SOPs: U.S. Geological Survey, accessed August 5, 2013, at http:// isotopes.usgs.gov/lab/methods.html.

U.S. Geological Survey, 2013b, National Water Quality Laboratory, all NWQL Water-Resources Publications: U.S. Geological Survey, accessed August 5, 2013, at http://nwql.usgs. gov/Public/rpt.shtml?pubs-all.

U.S. Geological Survey, variously dated, National field manual for the collection of water-quality data: U.S. Geological Survey Techniques of Water-Resources Investigations, book 9, chaps. A1-A9. (Also available at http://pubs.water. usgs.gov/twri9A.)

Vogel, J.C., 1967, Investigation of groundwater flow with radiocarbon: Isotopes in hydrology: Vienna, International Atomic Energy Agency, p. 355-369.

Waite, H.A. and others, 1949, Progress report on the geology and ground-water hydrology of the lower Platte River valley, Nebraska, with a section on The chemical quality of the ground water, by H.A. Swensen: U.S. Geological Survey Circular 20, $211 \mathrm{p}$.

Walker, G.R., 1998, Using soil water tracers to estimate recharge-Part 7, in Zhang, L., and Walker, G.R., eds., Basics of recharge and discharge series 7: Collingwood, Victoria, Australia, CSIRO publishing, p. 36. 



\section{Tables and Appendixes}


Tables 2 and 3 from the report and tables 1-1 through 1-3 for the appendix are presented in a single Microsoft ${ }^{\circledR}$ Excel spreadsheet available for download at http://pubs.usgs.gov/sir/2014/5008/downloads/Tables.xlsx.

\section{Tables}

Table 2. Particle size analyses, percent volumetric water content, bulk density, and percent gravimetric water content determined from selected soil-core samples collected 2008-10, Central Platte Natural Resources District unsaturated-zone network.

Table 3. Anion concentrations and volumetric water content in core samples collected spring 2012, Central Platte Natural Resources District unsaturated-zone network.

\section{Appendix Tables}

Table 1-1. Concentrations of selected water-quality constituents from monitoring wells in the Central Platte Natural Resources District unsaturated-zone network, 2009-10.

Table 1-2. Mean annual precipitation, selected physical characteristics of samples from soil cores used in recharge analyses, selected site characteristics, and concentrations for environmental samples and averaged concentrations of dissolved gases used for groundwater-age modeling. Samples from monitoring wells in the Central Platte Natural Resources District unsaturated-zone network, 2009-10.

Table 1-3. Constituents detected in blank samples and comparison of replicate samples from monitoring wells in the Central Platte Natural Resources District unsaturated-zone network, 2009-10.

Publishing support provided by:

Rolla and West Trenton Publishing Service Centers

For more information concerning this publication, contact:

Director, USGS Nebraska Water Science Center

5231 South 19th Street

Lincoln, Nebraska 68512

(402) 328-4100

Or visit the Nebraska Water Science Center Web site at: http://ne.water.usgs.gov/ 

